Prepared in cooperation with the Indianapolis Department of Public Works, Engineering Division

\title{
Biological Assessment and Streambed-Sediment Chemistry of Streams in the Indianapolis Metropolitan Area, Indiana, 2003-2008
}

Scientific Investigations Report 2012-5096 
Cover. Stream Ecosystem. (Painting by Rick Hill, Kentucky Department of Fish and Wildlife Resources.) 


\section{Biological Assessment and Streambed- Sediment Chemistry of Streams in the Indianapolis Metropolitan Area, Indiana, 2003-2008}

By David C. Voelker

Prepared in cooperation with the Indianapolis Department of Public Works, Engineering Division

Scientific Investigations Report 2012-5096 


\title{
U.S. Department of the Interior \\ KEN SALAZAR, Secretary
}

\author{
U.S. Geological Survey \\ Marcia K. McNutt, Director
}

U.S. Geological Survey, Reston, Virginia: 2012

For more information on the USGS - the Federal source for science about the Earth, its natural and living resources, natural hazards, and the environment, visit http://www.usgs.gov or call 1-888-ASK-USGS.

For an overview of USGS information products, including maps, imagery, and publications, visit http://www.usgs.gov/pubprod

To order this and other USGS information products, visit http://store.usgs.gov

Any use of trade, product, or firm names is for descriptive purposes only and does not imply endorsement by the U.S. Government.

Although this report is in the public domain, permission must be secured from the individual copyright owners to reproduce any copyrighted materials contained within this report.

Suggested citation:

Voelker, D.C., 2012, Biological assessment and streambed-sediment chemistry of streams in the Indianapolis metropolitan area, Indiana, 2003-2008: U.S. Geological Survey Scientific Investigations Report 2012-5096, 53 p., plus 3 appendixes. 


\section{Contents}

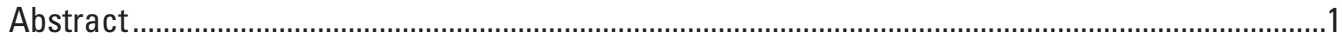

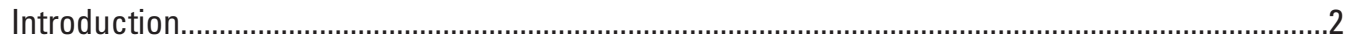

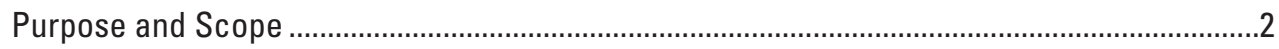

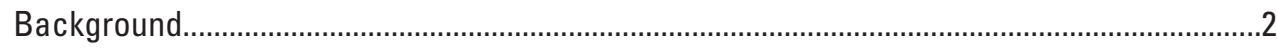

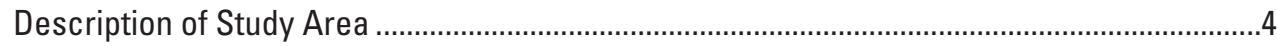

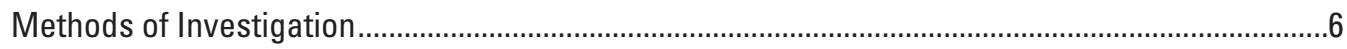

Benthic Invertebrates ..........................................................................................................

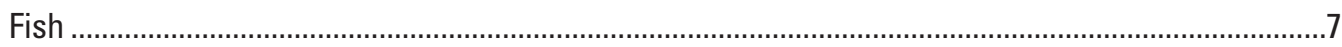

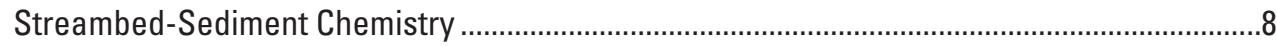

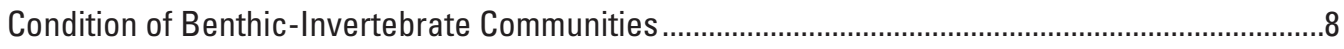

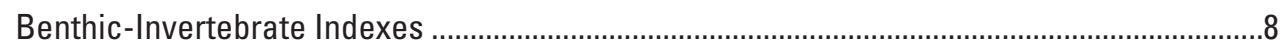

Ephemeroptera, Plecoptera, Trichoptera (EPT) Index................................................

Hilsenhoff Biotic Index (HBI) .................................................................................. 13

Invertebrate Community Index (ICI) ............................................................................13

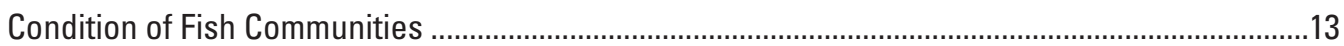

Index of Biotic Integrity (IBI) ..............................................................................................

Streambed-Sediment Chemistry ................................................................................................. 19

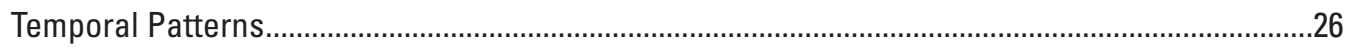

Ephemeroptera, Plecoptera, and Trichoptera (EPT) Index .....................................................26

Hilsenhoff Biotic Index (HBI) Scores........................................................................................26

Invertebrate Community Index (ICI) Scores.............................................................................26

Changes in Pollution-Tolerant and Pollution-Intolerant Benthic-Invertebrate

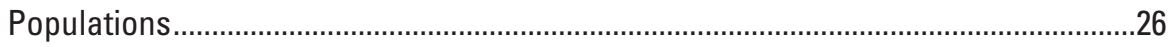

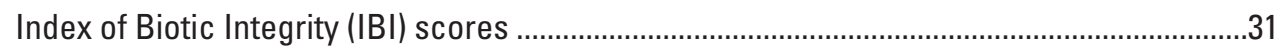

Streambed-Sediment Chemistry .............................................................................................

Combining Metrics to Evaluate Biological Response to CSOs .......................................................31

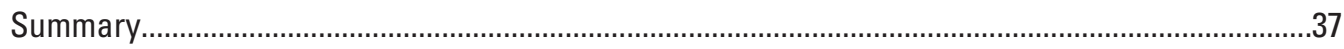

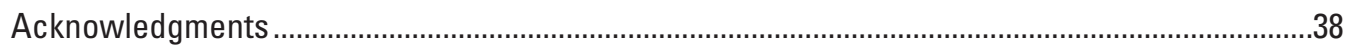

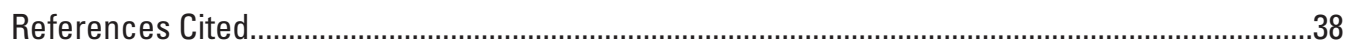

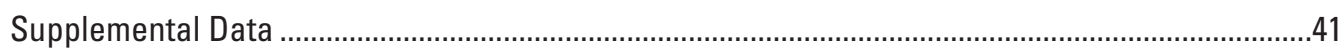

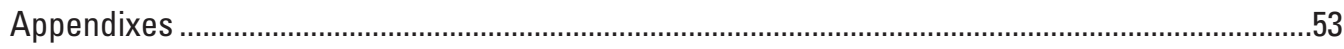

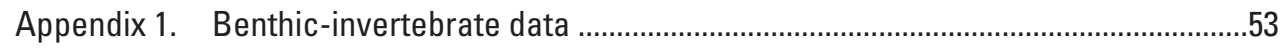

Appendix 2. Fish-community data ..................................................................................53

Appendix 3. Streambed-sediment chemistry data ..........................................................53 


\section{Figures}

1. Map showing location of the study area and site locations on the White River and tributaries in the Indianapolis metropolitan area.

2. Boxplots showing diversity of the benthic-invertebrate population, 2003-2008.

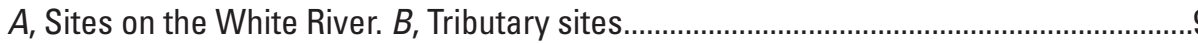

3. Boxplots showing density of benthic invertebrates, 2003-2008. $A$, Sites on the White River. $B$, Tributary sites.

4. Boxplots showing Ephemeroptera, Plecoptera, and Trichoptera (EPT) Index scores, 2003-2008. A, Sites on the White River. B, Tributary sites

5. Boxplots showing Hilsenhoff Biotic Index (HBI) scores, 2003-2008. $A$, Sites on the White River. $B$, Tributary sites.

6. Boxplots showing Invertebrate Community Index (ICI) scores, 2003-2008. $A$, Sites on the White River. $B$, Tributary sites.

7. Graphs showing Index of Biotic Integrity (IBI) scores, 2006 and 2008. $A$, Sites on the White River. $B$, Tributary sites.

8. Graphs showing number of sites at which chlorinated pesticides were detected in streambed-sediment samples. $A, 2005 . B, 2007$

9. Graphs showing number of sites at which organophosphate pesticides were detected in streambed sediment samples. A, 2005. B, 2007

10. Graphs showing number of sites at which selected semivolatile organic compounds (SVOCs) were detected in streambed sediments, 2005

11. Graphs showing number of sites at which selected semivolatile organic compounds (SVOCs) were detected in streambed sediments, 2007

12. Boxplots showing Ephemeroptera, Plecoptera, and Trichoptera (EPT) Index scores, 1981-2008

13. Boxplots showing Hilsenhoff Biotic Index (HBI) scores, 1981-2008_..............................28

14. Boxplots showing Invertebrate Community Index (ICI) scores, 1999-2008 .....................29

15. Graphs showing historical percentage of pollution-tolerant and pollution-intolerant benthic invertebrates at selected sites on the White River, 1981-2008.....

16. Graphs showing historical percentage of pollution-tolerant and pollution-intolerant benthic invertebrates at White River sites, 1994-2008..

17. Graphs showing historical percentage of pollution-tolerant and pollution-intolerant benthic invertebrates at tributary sites, 1994-2008

18. Boxplots showing historical Index of Biotic Integrity (IBI) scores, 1999-2008. $A$, Sites on the White River. $B$, Tributary sites. 


\section{Tables}

1. Sites sampled for benthic invertebrates, fish communities and streambedsediment chemistry in the Indianapolis metropolitan area, 2003-2008..

2. Discharge at U.S. Geological Survey streamflow-gaging stations in the study area, 2003-2008

3. Benthic-invertebrate taxa collected at all sites in the Indianapolis metropolitan area, 2003-2008

4. Ephemeroptera, Plecoptera, and Trichoptera (EPT) Index scores at all sites in the Indianapolis metropolitan area, 1981-2008.

5. Hilsenhoff Biotic Index (HBI) scores at all sites in the Indianapolis metropolitan area, 1981-2008

6. Invertebrate Community Index (ICI) scores at all sites in the Indianapolis metropolitan area, 1999-2008

7. Fish collected at the White River sites in the Indianapolis metropolitan area, 2006 and 2008.

8. Fish collected at the tributary sites in the Indianapolis metropolitan area, 2006 and 2008.

9. Fish anomalies observed at all sites in the Indianapolis metropolitan area during 2006 and 2008

10. Index of Biotic Integrity (IBI) scores at all sites in the Indianapolis metropolitan area, 2006 and 2008.

11. Freshwater-sediment Threshold Effect and Probable Effect Levels for the protection of aquatic life (modified from Canadian Council of Ministers of the Environment, 1995).

12. Index of Biotic Integrity (IBI) scores at all sites in the Indianapolis metropolitan area, 1999-2008

13. Ranking of sites by benthic invertebrate and fish metrics and index scores for sites on the White River and tributary sites in the Indianapolis metropolitan area, 1981-2008 


\section{Appendixes}

\section{Appendix 1}

Tables 1-1 to 1-178. Benthic-invertebrate data for:

June 2003-

1-1. White River near Nora, Ind.

1-2. White River near Nora, Ind.

1-3. White River at Morris Street at Indianapolis, Ind.

1-4. White River at Harding Street at Indianapolis, Ind.

1-5. White River below Stout Generating Station at Indianapolis, Ind.

1-6. White River at Wicker Road near Southport, Ind.

1-7. White River at Waverly, Ind.

1-8. Buck Creek 1.2 miles downstream from Maze Road near Brookfield, Ind.

1-9. Eagle Creek at Raymond Street at Indianapolis, Ind.

1-10. Fall Creek at 16th Street at Indianapolis, Ind.

1-11. Pleasant Run near South Meridian Street at Indianapolis, Ind.

1-12. Pogues Run at Vermont Street at Indianapolis, Ind.

1-13. Williams Creek at 96th Street at Indianapolis, Ind.

1-14. Williams Creek at 96th Street at Indianapolis, Ind.

November 2003-

1-15. White River near Nora, Ind.

1-16. White River at Morris Street at Indianapolis, Ind.

1-17. White River at Harding Street at Indianapolis, Ind.

1-18. White River below Stout Generating Station at Indianapolis, Ind.

1-19. White River at Wicker Road near Southport, Ind.

1-20. White River at Waverly, Ind.

1-21. Buck Creek 1.2 miles downstream from Maze Road near Brookfield, Ind.

1-22. Eagle Creek at Raymond Street at Indianapolis, Ind.

1-23. Fall Creek at 16th Street at Indianapolis, Ind.

1-24. Pleasant Run near South Meridian Street at Indianapolis, Ind.

1-25. Pleasant Run near South Meridian Street at Indianapolis, Ind.

1-26. Pogues Run at Vermont Street at Indianapolis, Ind.

1-27. Williams Creek at 96th Street at Indianapolis, Ind.

1-28. Williams Creek at 96th Street at Indianapolis, Ind.

May 2004-

1-29. White River near Nora, Ind.

1-30. White River at Morris Street at Indianapolis, Ind.

1-31. White River at Harding Street at Indianapolis, Ind.

1-32. White River below Stout Generating Station at Indianapolis, Ind.

1-33. White River at Tibbs-Banta Landfill near Southport, Ind.

1-34. White River at Tibbs-Banta Landfill near Southport, Ind.

1-35. White River at Wicker Road near Southport, Ind. 
May 2004-(continued)

1-36. White River at Waverly, Ind.

1-37. Buck Creek 1.2 miles downstream from Maze Road near Brookfield, Ind.

1-38. Eagle Creek at Raymond Street at Indianapolis, Ind.

1-39. Fall Creek at 16th Street at Indianapolis, Ind.

1-40. Fall Creek at 16th Street at Indianapolis, Ind.

1-41. Pleasant Run near South Meridian Street at Indianapolis, Ind.

1-42. Pogues Run at Vermont Street at Indianapolis, Ind.

1-43. Williams Creek at 96th Street at Indianapolis, Ind.

September 2004-

1-44. White River near Nora, Ind.

1-45. White River at Morris Street at Indianapolis, Ind.

1-46. White River at Harding Street at Indianapolis, Ind.

1-47. White River below Stout Generating Station at Indianapolis, Ind.

1-48. White River at Tibbs-Banta Landfill near Southport, Ind.

1-49. White River at Tibbs-Banta Landfill near Southport, Ind.

1-50. White River at Wicker Road near Southport, Ind.

1-51. White River at Waverly, Ind.

1-52. Buck Creek 1.2 miles downstream from Maze Road near Brookfield, Ind.

1-53. Eagle Creek at Raymond Street at Indianapolis, Ind.

1-54. Eagle Creek at Raymond Street at Indianapolis, Ind.

1-55. Fall Creek at 16th Street at Indianapolis, Ind.

1-56. Pleasant Run near South Meridian Street at Indianapolis, Ind.

1-57. Pogues Run at Vermont Street at Indianapolis, Ind.

1-58. Williams Creek at 96th Street at Indianapolis, Ind.

May/June 2005-

1-59. White River near Nora, Ind.

1-60. White River at Morris Street at Indianapolis, Ind.

1-61. White River at Harding Street at Indianapolis, Ind.

1-62. White River below Stout Generating Station at Indianapolis, Ind.

1-63. White River at Tibbs-Banta Landfill near Southport, Ind.

1-64. White River at Wicker Road near Southport, Ind.

1-65. White River at Wicker Road near Southport, Ind.

1-66. White River at Waverly, Ind.

1-67. Buck Creek 1.2 miles downstream from Maze Road near Brookfield, Ind.

1-68. Buck Creek 1.2 miles downstream from Maze Road near Brookfield, Ind.

1-69. Eagle Creek at Raymond Street at Indianapolis, Ind.

1-70. Fall Creek at 16th Street at Indianapolis, Ind.

1-71. Pleasant Run near South Meridian Street at Indianapolis, Ind.

1-72. Pogues Run at Vermont Street at Indianapolis, Ind.

1-73. Williams Creek at 96th Street at Indianapolis, Ind. 
September/October 2005-

1-74. White River near Nora, Ind.

1-75. White River at Morris Street at Indianapolis, Ind.

1-76. White River at Harding Street at Indianapolis, Ind.

1-77. White River below Stout Generating Station at Indianapolis, Ind.

1-78. White River below Stout Generating Station at Indianapolis, Ind.

1-79. White River at Tibbs-Banta Landfill near Southport, Ind.

1-80. White River at Wicker Road near Southport, Ind.

1-81. White River at Waverly, Ind.

1-82. Buck Creek 1.2 miles downstream from Maze Road near Brookfield, Ind.

1-83. Eagle Creek at Raymond Street at Indianapolis, Ind.

1-84. Fall Creek at 16th Street at Indianapolis, Ind.

1-85. Pleasant Run near South Meridian Street at Indianapolis, Ind.

1-86. Pogues Run at Vermont Street at Indianapolis, Ind.

1-87. Pogues Run at Vermont Street at Indianapolis, Ind.

1-88. Williams Creek at 96th Street at Indianapolis, Ind.

June/July 2006-

1-89. White River near Nora, Ind.

1-90. White River at Morris Street at Indianapolis, Ind.

1-91. White River at Morris Street at Indianapolis, Ind.

1-92. White River at Harding Street at Indianapolis, Ind.

1-93. White River below Stout Generating Station at Indianapolis, Ind.

1-94. White River at Tibbs-Banta Landfill near Southport, Ind.

1-95. White River at Wicker Road near Southport, Ind.

1-96. White River at Waverly, Ind.

1-97. Buck Creek 1.2 miles downstream from Maze Road near Brookfield, Ind.

1-98. Eagle Creek at Raymond Street at Indianapolis, Ind.

1-99. Fall Creek at 16th Street at Indianapolis, Ind.

1-100. Fall Creek at 16th Street at Indianapolis, Ind.

1-101. Pleasant Run near South Meridian Street at Indianapolis, Ind.

1-102. Pogues Run at Vermont Street at Indianapolis, Ind.

1-103. Williams Creek at 96th Street at Indianapolis, Ind.

October 2006-

1-104. White River near Nora, Ind.

1-105. White River at Morris Street at Indianapolis, Ind.

1-106. White River at Harding Street at Indianapolis, Ind.

1-107. White River below Stout Generating Station at Indianapolis, Ind.

1-108. White River at Tibbs-Banta Landfill near Southport, Ind.

1-109. White River at Wicker Road near Southport, Ind.

1-110. White River at Waverly, Ind.

1-111. White River at Waverly, Ind.

1-112. Buck Creek 1.2 miles downstream from Maze Road near Brookfield, Ind.

1-113. Buck Creek 1.2 miles downstream from Maze Road near Brookfield, Ind. 
October 2006-(continued)

1-114. Eagle Creek at Raymond Street at Indianapolis, Ind.

1-115. Fall Creek at 16th Street at Indianapolis, Ind.

1-116. Pleasant Run near South Meridian Street at Indianapolis, Ind.

1-117. Pogues Run at Vermont Street at Indianapolis, Ind.

1-118. Williams Creek at 96th Street at Indianapolis, Ind.

May 2007-

1-119. White River near Nora, Ind.

1-120. White River at Morris Street at Indianapolis, Ind.

1-121. White River at Harding Street at Indianapolis, Ind.

1-122. White River at Harding Street at Indianapolis, Ind.

1-123. White River below Stout Generating Station at Indianapolis, Ind.

1-124. White River at Tibbs-Banta Landfill near Southport, Ind.

1-125. White River at Wicker Road near Southport, Ind.

1-126. White River at Waverly, Ind.

1-127. Buck Creek 1.2 miles downstream from Maze Road near Brookfield, Ind.

1-128. Eagle Creek at Raymond Street at Indianapolis, Ind.

1-129. Fall Creek at 16th Street at Indianapolis, Ind.

1-130. Pleasant Run near South Meridian Street at Indianapolis, Ind.

1-131. Pleasant Run near South Meridian Street at Indianapolis, Ind.

1-132. Pogues Run at Vermont Street at Indianapolis, Ind.

1-133. Williams Creek at 96th Street at Indianapolis, Ind.

September 2007-

1-134. White River near Nora, Ind.

1-135. White River near Nora, Ind.

1-136. White River at Morris Street at Indianapolis, Ind.

1-137. White River at Harding Street at Indianapolis, Ind.

1-138. White River below Stout Generating Station at Indianapolis, Ind.

1-139. White River at Tibbs-Banta Landfill near Southport, Ind.

1-140. White River at Wicker Road near Southport, Ind.

1-141. White River at Waverly, Ind.

1-142. Buck Creek 1.2 miles downstream from Maze Road near Brookfield, Ind.

1-143. Eagle Creek at Raymond Street at Indianapolis, Ind.

1-144. Eagle Creek at Raymond Street at Indianapolis, Ind.

1-145. Fall Creek at 16th Street at Indianapolis, Ind.

1-146. Pleasant Run near South Meridian Street at Indianapolis, Ind.

1-147. Pogues Run at Vermont Street at Indianapolis, Ind.

1-148. Williams Creek at 96th Street at Indianapolis, Ind.

June 2008-

1-149. White River near Nora, Ind.

1-150. White River at Morris Street at Indianapolis, Ind.

1-151. White River at Harding Street at Indianapolis, Ind.

1-152. White River below Stout Generating Station at Indianapolis, Ind. 
June 2008-(continued)

1-153. White River at Tibbs-Banta Landfill near Southport, Ind.

1-154. White River at Tibbs-Banta Landfill near Southport, Ind.

1-155. White River at Wicker Road near Southport, Ind.

1-156. White River at Waverly, Ind.

1-157. Buck Creek 1.2 miles downstream from Maze Road near Brookfield, Ind.

1-158. Eagle Creek at Raymond Street at Indianapolis, Ind.

1-159. Fall Creek at 16th Street at Indianapolis, Ind.

1-160. Pleasant Run near South Meridian Street at Indianapolis, Ind.

1-161. Pogues Run at Vermont Street at Indianapolis, Ind.

1-162. Pogues Run at Vermont Street at Indianapolis, Ind.

1-163. Williams Creek at 96th Street at Indianapolis, Ind.

September 2008-

1-164. White River near Nora, Ind.

1-165. White River at Morris Street at Indianapolis, Ind.

1-166. White River at Harding Street at Indianapolis, Ind.

1-167. White River below Stout Generating Station at Indianapolis, Ind.

1-168. White River below Stout Generating Station at Indianapolis, Ind.

1-169. White River at Tibbs-Banta Landfill near Southport, Ind.

1-170. White River at Wicker Road near Southport, Ind.

1-171. White River at Wicker Road near Southport, Ind.

1-172. White River at Waverly, Ind.

1-173. Buck Creek 1.2 miles downstream from Maze Road near Brookfield, Ind.

1-174. Eagle Creek at Raymond Street at Indianapolis, Ind.

1-175. Fall Creek at 16th Street at Indianapolis, Ind.

1-176. Pleasant Run near South Meridian Street at Indianapolis, Ind.

1-177. Pogues Run at Vermont Street at Indianapolis, Ind.

1-178. Williams Creek at 96th Street at Indianapolis, Ind.

\section{Appendix 2}

Tables 2-1 to 2-26. Fish-community data for:

2006-

2-1. White River near Nora, Ind.

2-2. White River at Morris Street at Indianapolis, Ind.

2-3. White River at Harding Street at Indianapolis, Ind.

2-4. White River below Stout Generating Station at Indianapolis, Ind.

2-5. White River at Tibbs-Banta Landfill near Southport, Ind.

2-6. White River at Wicker Road near Southport, Ind.

2-7. White River at Waverly, Ind.

2-8. Buck Creek 1.2 miles downstream from Maze Road near Brookfield, Ind.

2-9. Eagle Creek at Raymond Street at Indianapolis, Ind.

2-10. Fall Creek at 16th Street at Indianapolis, Ind.

2-11. Pleasant Run near South Meridian Street at Indianapolis, Ind.

2-12. Pogues Run at Vermont Street at Indianapolis, Ind.

2-13. Williams Creek at 96th Street at Indianapolis, Ind. 
2008

2-14. White River near Nora, Ind.

2-15. White River at Morris Street at Indianapolis, Ind.

2-16. White River at Harding Street at Indianapolis, Ind.

2-17. White River below Stout Generating Station at Indianapolis, Ind.

2-18. White River at Tibbs-Banta Landfill near Southport, Ind.

2-19. White River at Wicker Road near Southport, Ind.

2-20. White River at Waverly, Ind.

2-21. Buck Creek 1.2 miles downstream from Maze Road near Brookfield, Ind.

2-22. Eagle Creek at Raymond Street at Indianapolis, Ind.

2-23. Fall Creek at 16th Street at Indianapolis, Ind.

2-24. Pleasant Run near South Meridian Street at Indianapolis, Ind.

2-25. Pogues Run at Vermont Street at Indianapolis, Ind.

2-26. Williams Creek at 96th Street at Indianapolis, Ind.

\section{Appendix 3}

Tables 3-1 to 3-6. Streambed-sediment chemistry data

3-1. Physical water-quality properties for sites on the White River and selected tributaries in the Indianapolis metropolitan area, Indiana, 2005 and 2007.

3-2. Carbon-species concentrations in streambed sediments for sites on the White River and selected tributaries in the Indianapolis metropolitan area, Indiana, 2005 and 2007.

3-3. Chlorinated pesticide concentrations in streambed sediments for sites on the White River and selected tributaries in the Indianapolis metropolitan area, Indiana, 2005 and 2007.

3-4. Organophosphate pesticide concentrations in streambed sediments for sites on the White River and selected tributaries in the Indianapolis metropolitan area, Indiana, 2005 and 2007.

3-5. Concentrations of inorganic constituents in streambed sediments for sites on the White River and selected tributaries in the Indianapolis metropolitan area, Indiana, 2005 and 2007.

3-6. Semivolatile organic carbon concentrations in streambed sediments for sites on the White River and selected tributaries in the Indianapolis metropolitan area, Indiana, 2005 and 2007. 


\section{Conversion Factors}

\begin{tabular}{|c|c|c|}
\hline Multiply & By & To obtain \\
\hline \multicolumn{3}{|c|}{ Length } \\
\hline mile (mi) & 1.609 & kilometer $(\mathrm{km})$ \\
\hline \multicolumn{3}{|c|}{ Area } \\
\hline square mile $\left(\mathrm{mi}^{2}\right)$ & 2.590 & square kilometer $\left(\mathrm{km}^{2}\right)$ \\
\hline \multicolumn{3}{|c|}{ Flow rate } \\
\hline cubic foot per second $\left(\mathrm{ft}^{3} / \mathrm{s}\right)$ & 0.02832 & cubic meter per second $\left(\mathrm{m}^{3} / \mathrm{s}\right)$ \\
\hline million gallons per day (Mgal/d) & 0.04381 & cubic meter per second $\left(\mathrm{m}^{3} / \mathrm{s}\right)$ \\
\hline
\end{tabular}

\begin{tabular}{|c|c|c|}
\hline Multiply & By & To obtain \\
\hline \multicolumn{3}{|c|}{ Length } \\
\hline centimeter $(\mathrm{cm})$ & 0.3937 & inch (in.) \\
\hline millimeter $(\mathrm{mm})$ & 0.03937 & inch (in.) \\
\hline meter $(\mathrm{m})$ & 3.281 & foot $(\mathrm{ft})$ \\
\hline \multicolumn{3}{|c|}{ Area } \\
\hline square meter $\left(\mathrm{m}^{2}\right)$ & 10.76 & square foot $\left(\mathrm{ft}^{2}\right)$ \\
\hline \multicolumn{3}{|c|}{ Mass } \\
\hline gram (g) & 0.03527 & ounce, avoirdupois (oz) \\
\hline kilogram (kg) & 2.205 & pound avoirdupois (lb) \\
\hline
\end{tabular}

Temperature in degrees Celsius $\left({ }^{\circ} \mathrm{C}\right)$ may be converted to degrees Fahrenheit $\left({ }^{\circ} \mathrm{F}\right)$ as follows:

${ }^{\circ} \mathrm{F}=\left(1.8 x^{\circ} \mathrm{C}\right)+32$

Horizontal coordinate information is referenced to the North American Datum of 1983 (NAD 83).

Specific conductance is given in microsiemens per centimeter at 25 degrees Celsius $(\mu \mathrm{S} / \mathrm{cm}$ at $\left.25^{\circ} \mathrm{C}\right)$.

Concentrations of chemical constituents in bed sediments are given either in grams per kilogram $(\mathrm{g} / \mathrm{kg}$ ) or micrograms per kilogram $(\mu \mathrm{g} / \mathrm{kg})$.

Concentrations of dissolved oxygen in water are given as milligrams per liter $(\mathrm{mg} / \mathrm{L})$. 


$\begin{array}{ll}\text { Abbreviations and initialisms used in this report: } \\ \text { CSO } & \text { Combined-sewer overflow } \\ \text { CSS } & \text { Combined-sewer system } \\ \text { DPW } & \text { Department of Public Works (Indianapolis) } \\ \text { EPA } & \text { U.S. Environmental Protection Agency } \\ \text { EPT } & \text { Ephemeroptera, Plecoptera, and Trichoptera Index } \\ \text { HBI } & \text { Hilsenhoff Biotic Index } \\ \text { IBI } & \text { Index of Biotic Integrity } \\ \text { ICI } & \text { Invertebrate Community Index } \\ \text { NAWQA } & \text { National Water-Quality Assessment Program } \\ \text { NWOL } & \text { National Water Quality Laboratory } \\ \text { Ohio EPA } & \text { Ohio Environmental Protection Agency } \\ \text { PCB } & \text { Polychlorinated biphenyls } \\ \text { PEL } & \text { Probable effect level } \\ \text { SVOC } & \text { Semivolatile organic compounds } \\ \text { TEL } & \text { Threshold effect level } \\ \text { USGS } & \text { U.S. Geological Survey } \\ \text { WWTF } & \text { Wastewater-treatment facility } \\ & \end{array}$





\title{
Biological Assessment and Streambed-Sediment Chemistry of Streams in the Indianapolis Metropolitan Area, Indiana, 2003-2008
}

\author{
By David C. Voelker
}

\section{Abstract}

During 2003-2008, the U.S. Geological Survey sampled 13 sites in the Indianapolis metropolitan area in Indiana for benthic invertebrates, fish communities, and streambed-sediment chemistry. Data from seven White River sites and six tributary sites complement surface-water chemistry data collected by the Indianapolis Department of Public Works. The information is being used to assess changes in water quality in conjunction with the City's programs to reduce combined sewer overflows and other point and nonpoint sources of pollution in the Indianapolis area.

During the study, 233 benthic-invertebrate taxa were identified from which the Ephemeroptera, Plecoptera, and Trichoptera (EPT) Index, the Hilsenhoff Biotic Index (HBI), and the Invertebrate Community Index (ICI) were calculated. EPT index scores ranged from 2 to 16 on the White River and from 2 to 17 on the tributaries. EPT index scores indicate that these pollution-intolerant taxa are more prevalent upstream from and away from the combined-sewer areas of Indianapolis. HBI scores from sites on the White River ranged from 4.67 (good) to 9.55 (very poor), whereas on the tributaries, scores ranged from 4.21 (very good) to 8.14 (poor). Lower HBI scores suggest that less organic pollution was present and, like the EPT scores, indicate better conditions where combined-sewer overflows (CSOs) are not present. Similarly, ICI scores indicated better conditions upstream from the CSO outfalls on the White River. White River scores ranged from 12 to 46, where higher ICI scores indicate better conditions in the benthic-invertebrate community. ICI scores at the tributary sites ranged from 12 to 52, with the highest scores on streams without CSOs.

Fish-community data collected during 2006 and 2008 identified 65 taxa (51 on the White River and 53 on tributaries). The Centrarchidae (sunfishes) were the predominant fishes collected on the White River, while the Cyprinidae (carps and minnows) were predominant on the tributaries. Index of Biotic Integrity (IBI) scores ranged from 20 to 52 on the White River and from 26 to 52 on the tributaries. White River scores all improved from 2006 to 2008.
Streambed sediments were collected at the study sites in 2005 and 2007. The number of chlorinated pesticides detected in those samples increased in 2007, with trans-nonachlor, cis-chlordane, dieldrin, trans-chlordane, and PCBs being most frequently detected. Three organophosphate insecticides were detected. More than 30 semivolatile organic compounds (SVOCs) were detected at more than half the sites sampled. Sites below CSO outfalls had higher concentrations of SVOCs, whereas sites not near CSOs had lower concentrations.

Historical biological data consistently indicated that the Nora site - upstream from CSO influence - showed the least impairment among the White River sites. The data also indicated that the Morris and Harding sites - closest to the CSOs - showed the poorest biological conditions on the White River. The Buck Creek site, followed by the Williams Creek site, scored best among the tributaries, whereas the most urban sites-Fall Creek, Pleasant Run, and Pogues Run - scored the poorest.

Historical numbers of pollution-tolerant and pollutionintolerant organisms in the White River reflect changes at the wastewater treatment facilities in 1983 to tertiary treatment, including ozonation, and in 1994 to chlorination. The advent of ozone treatment of the effluents had a positive effect on the benthic-invertebrate communities downstream from the wastewater treatment facilities. The benthic-invertebrate communities at the upstream site exhibited minor yearly variations until a chemical spill in 1999 had a dramatic impact on the biological communities in the river, including the killing of thousands of fish.

Historical IBI data collection began in 1999 and show that fairly stable fish communities are present in the study area. Like the benthic-invertebrate data, the IBI scores reflect more pollution-tolerant fish communities near the CSOaffected sites. Only the Waverly site on the White River and the Pogues Run site appear to have slightly decreased IBI scores with time, whereas the remaining sites showed only minor year to year variations. 


\section{Introduction}

\section{Purpose and Scope}

This report describes the abundance and diversity of benthic-invertebrate and fish communities and analyses of streambed-sediment chemistry at 13 sites in and around Marion County, Indiana (fig. 1), with emphasis on biotic and streambed-sediment data collected from 2003 through 2008. The data are used to describe the effects that combined-sewer overflows (CSOs) have on receiving streams through differences in biological communities in the CSO-served areas. Benthic invertebrates were collected twice yearly from 2003 through 2008, fish communities were sampled once during 2006 and 2008, and streambed sediments were sampled and chemically analyzed during 2005 and 2007. Methods of study are described and the data are presented in tables and graphs.

This report uses the biological and sediment data to evaluate the location of impaired biological communities relative to areas that receive effluent from CSOs, wastewater treatment facilities, or urbanized areas. The report evaluates biological data by use of biotic indexes to assess the biological condition of the aquatic environment. Benthic-invertebrate communities were assessed with the Ephemeroptera, Plecoptera, and Trichoptera (EPT) index, a modified Hilsenhoff Biotic Index (HBI) (Hilsenhoff, 1987), and the Invertebrate Community Index (ICI) (Ohio Environmental Protection Agency, 1987). Fish communities were assessed with an Index of Biotic Integrity (IBI). These biological indexes are described, and the results of the analyses are presented. The results indicate how biotic conditions have changed with time. Streambed-sediment chemistry data also are presented. Long-term variations in the data are discussed and referenced to historical data collected during previous cooperative studies from 1981 through 2001 between the U.S. Geological Survey (USGS) and the Indianapolis Department of Public Works (DPW).

\section{Background}

The DPW manages the combined-sewer system (CSS) and is responsible for implementing control strategies to mediate the effects of CSOs on water quality of receiving streams in and around Marion County, including the City of Indianapolis. A CSS is designed, constructed, and operated to carry both sanitary sewage and stormwater runoff in the same system. Diversion structures within the CSS route sanitary sewage to the wastewater-treatment facility (WWTF) during dry weather. During wet weather, the CSS often discharges directly to surface water via CSO outfalls (State of Indiana, 1996).

The U.S. Environmental Protection Agency (EPA) (1999), in its guidance document for monitoring and modeling of CSOs, states that baseline conditions of the receiving water need to be defined. The DPW has an ongoing program to collect and analyze surface-water samples within Marion County; however, if chemical analysis of samples is used as the sole method to determine water quality, substantial effects on the biological communities such as habitat degradation, siltation, and flow alterations can be missed. Therefore, the DPW proposed using biological indicators to monitor the overall health of the White River and its tributaries (City of Indianapolis, 2000).

Evaluation of stream biota is one way to determine cumulative effects of CSOs on water quality because the aquatic organisms are affected by long-term exposure to a variety of environmental stressors, including CSO and WWTF effluent; however, because biological indicators reflect the overall effects from all pollution sources entering the receiving waters, it would be difficult to attribute existing biological conditions directly to the CSOs alone. The EPA (1999) also suggested that investigators should (1) limit the use of biotic indexes as general indicators of environmental effects and (2) limit comparisons within a study to those sites where sampling and sample-analysis methods have been consistent over time.

Receiving waters in the study area for CSO and WWTF effluent include the White River, Pogues Run, Pleasant Run, Eagle Creek, and Fall Creek (fig. 1). Williams Creek and Buck Creek are tributaries of the White River that do not have CSO inputs but can be subject to input from septic systems or sanitary-sewer failures. Because there is little, if any, upstream input from the Indianapolis sewer system, sites at Nora (on the White River) and on Williams and Buck Creeks are considered for the purposes of this study to be the control sites (unaffected by CSOs) for comparing data within the study area.

To achieve the objectives of the Clean Water Act (U.S. Environmental Protection Agency, 2002), comprehensive information about the ecological integrity of aquatic environments is needed. Biotic integrity is described by Karr and Dudley (1981) as the ability to support and maintain a balanced, integrated, and adaptive community of organisms having a species composition, diversity, and functional organization comparable to that of the natural habitat of a region. Biotic integrity may be the most critical assessment of the water quality of streams because stream biota are subject to a full range of environmental influences (chemical, physical, and biological). Many stream biota complete most or all of their life cycles in the water, thereby serving as continuous monitors of environmental quality. Biological criteria can indicate water-quality impairments, provide data in support of regulatory controls that address water-quality problems, and assess improvements in water quality from regulatory efforts. Biological criteria complement water-quality programs that focus on direct measures of water chemistry and physical properties of the aquatic environment. 


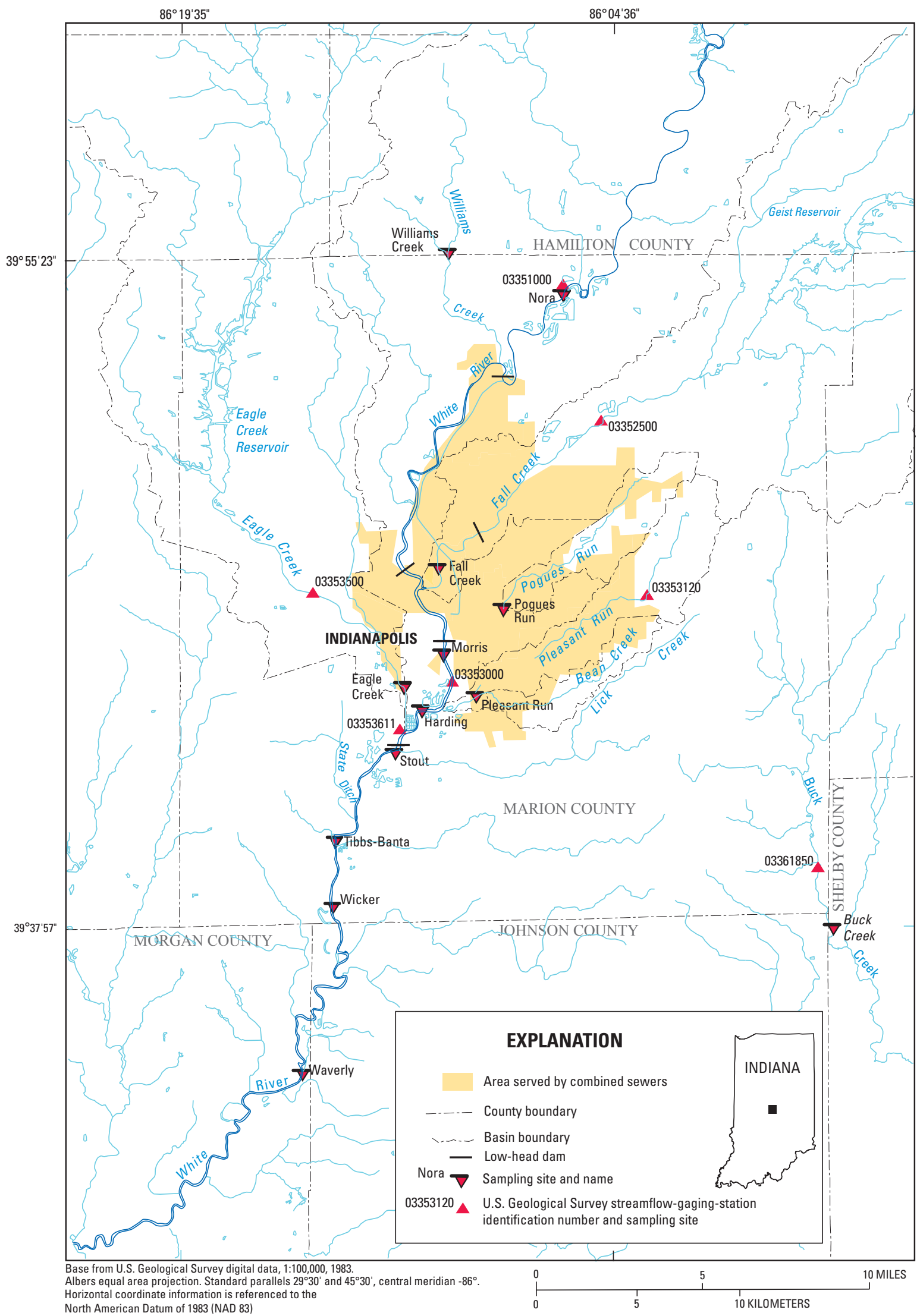

Figure 1. Location of the study area and site locations on the White River and tributaries in the Indianapolis metropolitan area. 
Benthic-invertebrate and fish-community assessments are used as measures of biotic integrity in streams and rivers. Benthic invertebrates have limited mobility and can be used as indicators of the long-term effects of water quality in streams. Benthic invertebrates can be found in all but the most severely polluted habitats. Fish communities, although much more mobile than benthic invertebrates, can also represent waterquality conditions in a stream. Fish communities are sensitive to a wide variety of environmental factors such as habitat degradation, siltation, pesticides, nutrients (primarily nitrogen and phosphorus), and alterations in streamflow. Absence of fish from a stream may be due to natural or human-induced causes, such as dams or shallow riffles that obstruct fish passage along a stream reach. Diversity among fish communities can be affected by colonization rates, the presence of suitable habitat, extinction rates, competition, predation, physical disturbances, pollution, and other factors (Crowder, 1990).

Streambed-sediment chemistry was investigated to complement the biological data collected by the USGS and streamwater-chemisty data being collected by the DPW Office of Environmental Services. Streambed-sediment sampling helped determine which chemical constituents were attached to the sediments of the Indianapolis metropolitan area and thereby helped explain differences in the biological communities at each site. Streambed sediments strongly affect biological communities because metals and organic chemicals can bind with benthic organic matter, which is a major food source for some stream invertebrates (Benke and Wallace, 1997). Mortality of aquatic invertebrates can be high in urban streams and can indicate possible toxicity associated with streambedsediment contact or ingestion of toxins associated with the sediments (Pratt and others, 1981; Medeiros and others, 1983). Rochfort and others (2000) indicate that runoff from urban areas, including municipal wastewater discharge, produces increased contaminant loads to streams that often cause a decline in the numbers of taxa (richness) of biological communities in urban streams. Chemical effects of urbanization are variable and depend on the type of urbanization, presence of WWTF effluents and/or CSOs, and the extent of stormwater drainage (Paul and Meyer, 2001). Urbanization is second only to agriculture as a major cause of stream impairment (Paul and Meyer, 2001).

Data collected for this project complement (1) data collected by prior cooperative studies between the DPW and USGS and (2) monthly chemical monitoring of surface waters by the DPW. In the early 1980s, the USGS, in cooperation with the DPW, began a study to assess changes in the benthicinvertebrate communities in the White River in response to changes and upgrades in Indianapolis WWTFs (Crawford and others, 1992). In the 1990s, a second study was begun to assess biological communities and streambed-sediment chemistry in the White River and selected tributaries relative to CSO issues that the City was assessing (Renn, 1998; Voelker and Renn, 2000). A third study during 1999-2001 included benthic-invertebrate and fish communities (Voelker, 2004). During 2003 and 2004, collection of benthic-invertebrate samples resumed. In 2005, there was renewed interest in continued monitoring, and a 4-year cooperative study ensued. Although the biological condition of the studied streams cannot be attributed solely to effects from CSOs, it does reflect the overall effect from all sources entering the receiving waters.

\section{Description of Study Area}

Indianapolis is the capital of Indiana and largest city in the State. The city is incorporated with Marion County, and covers approximately 402 square miles $\left(\mathrm{mi}^{2}\right)$. Approximately $41 \mathrm{mi}^{2}$ are served by a CSO system (fig. 1). In 2007, this system had approximately 130 CSOs that discharged into the White River directly or into several of its tributaries. The rest of the sewer system in Indianapolis consists of separate sanitary and storm sewers and covers slightly more than $200 \mathrm{mi}^{2}$. The remaining areas of Indianapolis not served by CSOs or other sewers use private septic systems, but most of these areas are gradually being converted to sanitary sewers (City of Indianapolis, 2007).

The study area is in the Central climate division in Indiana, which is characterized by hot, humid summers and cold, wet winters (Newman, 1966). Physiographically, the study area is within the Eastern Corn Belt Plains ecoregion (Woods and others, 1998). Crop production, primarily corn and soybeans, is the predominant land use outside of the urban areas of Indianapolis (Simon and Dufour, 1997).

The total drainage area of the White River is 5,372 $\mathrm{mi}^{2}$ at the confluence with the East Fork White River. At the most downstream site sampled (Waverly) the drainage area is 2,026 $\mathrm{mi}^{2}$. The drainage area at the most upstream site sampled (Nora) is 1,219 $\mathrm{mi}^{2}$ (Hoggatt, 1975) (table 1). In addition to the CSOs, large inputs to the White River are discharges from the Belmont and Southport WWTFs in the southern reaches of the study area and the Carmel WWTF approximately 3 river miles upstream from the Nora site. The Belmont WWTF has a capacity of 120 million gallons per day $(\mathrm{Mgal} / \mathrm{d})$, with peak flows up to $300 \mathrm{Mgal} / \mathrm{d}$. The Southport facility can handle $125 \mathrm{Mgal} / \mathrm{d}$, with peak flows to $180 \mathrm{Mgal} / \mathrm{d}$. Together, the two Indianapolis WWTFs treat more than 70 billion gallons of wastewater each year (City of Indianapolis, 2007).

Annual mean discharges at the 10 streamflow-gaging stations in the study area (table 2) were mostly higher than the mean discharge for the period of record. Annual mean discharges at the four White River sites ranged from 102 to 178 percent of the mean discharge for the period of record at those sites. Similarly, at four of the tributary sites, annual mean discharges ranged from 90 to 169 percent of the mean discharge for the period of record.

Two of the tributary streamflow-gaging stations operated for only 1 year during the study period. Four of the eight streamflow-gaging stations have been in operation for periods that ranged from 16 to 78 years; those stations had the highest annual mean discharges recorded at those sites in either 2007 or 2008 . 
Table 1. Sites sampled for benthic invertebrates, fish communities, and streambed-sediment chemistry in the Indianapolis metropolitan area, 2003-2008.

[USGS, U.S. Geological Survey; ddmmss, degrees minutes seconds; Ind., Indiana; nr, near; mi, miles; DS, downstream]

\begin{tabular}{|c|c|c|c|c|c|c|c|c|}
\hline \multirow[b]{2}{*}{ Station name } & \multirow[b]{2}{*}{$\begin{array}{c}\text { USGS station } \\
\text { number }\end{array}$} & \multirow[b]{2}{*}{$\begin{array}{l}\text { Latitude } \\
\text { (ddmmss) }\end{array}$} & \multirow[b]{2}{*}{$\begin{array}{l}\text { Longitude } \\
\text { (ddmmss) }\end{array}$} & \multirow[b]{2}{*}{$\begin{array}{l}\text { River } \\
\text { mile }\end{array}$} & \multirow{2}{*}{$\begin{array}{c}\text { Drainage } \\
\text { area } \\
\text { (square } \\
\text { miles) }\end{array}$} & \multicolumn{3}{|c|}{ Year first sampled } \\
\hline & & & & & & Benthics & Fish & $\begin{array}{c}\text { Bed } \\
\text { sediment }\end{array}$ \\
\hline \multicolumn{9}{|c|}{ White River (boat sites) } \\
\hline White River near Nora ${ }^{1}$, Ind. & 03351000 & 395435 & -860620 & 247.9 & 1,219 & 1981 & 1999 & 1994 \\
\hline White River at Morris Street, Indianapolis, Ind. & 394505086103001 & 394515 & -861026 & 230.3 & 1,635 & 1994 & 1999 & 1994 \\
\hline White River at Harding Street, Indianapolis, Ind. & 03353193 & 394505 & -861030 & 227.9 & 1,660 & 1994 & 1999 & 1994 \\
\hline White River below Stout Generating Station, Indianapolis, Ind. & 394234086120900 & 394234 & -861209 & 226.2 & 1,898 & 1981 & 1999 & 1995 \\
\hline White River at Tibbs/Banta Landfill near Southport, Ind. & 394019086134601 & 394019 & -861346 & 222.5 & 1,920 & 1994 & 2005 & 1994 \\
\hline White River at Wicker Road near Southport, Ind. & 393827086141701 & 393827 & -861417 & 220.2 & 1,947 & 1994 & 1999 & 1994 \\
\hline White River at Waverly, Ind. & 03353660 & 393402 & -861518 & 211.0 & 2,026 & 1981 & 1999 & 1994 \\
\hline \multicolumn{9}{|c|}{ Tributaries: Wadeable sites } \\
\hline Eagle Creek at Raymond Street, Indianapolis, Ind. & 394613086114700 & 394411 & -861148 & 1.2 & 209 & 1994 & 1999 & 1994 \\
\hline Fall Creek at 16th Street, Indianapolis, Ind. & 03352875 & 394720 & -861040 & 1.3 & 317 & 1994 & 1999 & 1994 \\
\hline Pleasant Run nr South Meridian Street, Indianapolis, Ind. & 394358086092100 & 394358 & -860921 & 1.2 & 20.8 & 1994 & 1999 & 1994 \\
\hline Pogues Run at Vermont Street, Indianapolis, Ind. & 03352990 & 394617 & -860825 & 2.5 & 8.87 & 1994 & 1999 & 1994 \\
\hline \multicolumn{9}{|c|}{ Tributaries: Headwater sites } \\
\hline Buck Creek 1.2 mi DS Maze Road near Brookfield, Ind. & 393749086030501 & 393749 & -855656 & 1.9 & 81.9 & 1999 & 2000 & 2005 \\
\hline Williams Creek at 96th Street, Indianapolis, Ind. & 03351072 & 395537 & -861020 & 4.8 & 17 & 1994 & 1999 & 1994 \\
\hline
\end{tabular}

${ }^{1}$ Short name used throughout text to identify sites is in bold type. 
Table 2. Discharge at U.S. Geological Survey streamflow-gaging stations in the study area, 2003-2008.

[WY, water year; $\mathrm{ft}^{3} / \mathrm{s}$; cubic foot per second; --, not applicable]

\begin{tabular}{|c|c|c|c|c|c|c|c|c|c|}
\hline \multirow{3}{*}{$\begin{array}{l}\text { Station name } \\
\text { and number }\end{array}$} & \multirow{3}{*}{$\begin{array}{c}\text { River- } \\
\text { mile } \\
\text { Iocation }\end{array}$} & WY 2003 & WY 2004 & WY 2005 & WY 2006 & WY 2007 & WY 2008 & \multirow{2}{*}{\multicolumn{2}{|c|}{$\begin{array}{l}\text { Mean discharge } \\
\text { for the period of record }\end{array}$}} \\
\hline & & \multicolumn{6}{|c|}{ Percent normal flow for period of record } & & \\
\hline & & \multicolumn{6}{|c|}{ Annual mean discharge } & Period of & $\begin{array}{l}\text { Mean } \\
\text { discharge }\end{array}$ \\
\hline \multirow{2}{*}{$\begin{array}{l}\text { White River near Nora, } \\
03351000\end{array}$} & \multirow{2}{*}{247.9} & 152 & 126 & 148 & 122 & 173 & 161 & 78 years & \multirow[b]{2}{*}{1,191} \\
\hline & & 1,809 & 1,497 & 1,763 & 1,455 & $2,064 *$ & 1,918 & $1930-2008$ & \\
\hline \multirow{2}{*}{$\begin{array}{l}\text { White River at Stout Generating } \\
\text { Station, } 03353611\end{array}$} & \multirow{2}{*}{226.3} & 117 & 102 & 115 & 107 & 139 & 132 & 16 years & \multirow[b]{2}{*}{2,171} \\
\hline & & 2,539 & 2,205 & 2,504 & 2,320 & $3,006^{*}$ & 2,873 & 1992-2008 & \\
\hline \multirow{2}{*}{$\begin{array}{l}\text { White River at Centerton, } \\
03354000\end{array}$} & \multirow{2}{*}{199.3} & 136 & 118 & 131 & 116 & 154 & 156 & 60 years & \multirow[b]{2}{*}{2,654} \\
\hline & & 3,615 & 3,138 & 3,479 & 3,086 & 4,087 & $4,133^{*}$ & 1948-2008 & \\
\hline \multirow{2}{*}{$\begin{array}{l}\text { Fall Creek at Millersville, } \\
03352500\end{array}$} & \multirow{2}{*}{9.2} & 148 & 135 & 147 & 134 & 160 & 167 & 78 years & \multirow[b]{2}{*}{304} \\
\hline & & 450 & 411 & 446 & 407 & 485 & 509 & 1930-2008 & \\
\hline \multirow{2}{*}{$\begin{array}{l}\text { Pogues Run at Indianapolis, } \\
03352988\end{array}$} & \multirow{2}{*}{9.74} & -- & -- & -- & -- & -- & 100 & 1 year & \multirow[b]{2}{*}{9.95} \\
\hline & & -- & -- & -- & -- & -- & $9.95 *$ & $2007-2008$ & \\
\hline \multirow{2}{*}{$\begin{array}{l}\text { Pleasant Run at Arlington Ave. at } \\
\text { Indianapolis, } 03353120\end{array}$} & \multirow{2}{*}{7.9} & 118 & 147 & 142 & 133 & 145 & 153 & 48 years & \multirow[b]{2}{*}{8.69} \\
\hline & & 10.3 & 12.8 & 12.3 & 11.6 & 12.6 & $13.3 *$ & 1960-2008 & \\
\hline \multirow{2}{*}{$\begin{array}{l}\text { Williams Creek at 96th St., } \\
03351072\end{array}$} & 513 & -- & -- & -- & -- & -- & 100 & 1 year & \\
\hline & 5.13 & -- & -- & -- & -- & -- & $36.0^{*}$ & $2007-2008$ & 36.0 \\
\hline
\end{tabular}

* Highest annual mean discharge for the period of record.

\section{Methods of Investigation}

Thirteen sites were sampled in the study area, seven of which were on the White River and six on tributaries to the White River (table 1). Most sites were selected to coincide with sites used by the Indianapolis Department of Public Works for monthly water-quality sampling. In addition, several sites were selected to maintain continuity of data collection from previous studies and allow for historical comparison of data. During 2003 and 2004, only benthic-invertebrate data were collected. In 2005 and 2007, benthic invertebrates and bed sediments were sampled, whereas in 2006 and 2008, benthic invertebrates and fish communities were assessed.

Voelker (2004) described sampling locations and conditions for 12 of the sites used in the previous study. Seven are along the White River as it travels through Marion County and into Morgan County (fig. 1). Nora, the most upstream site, is the only site upstream from the CSO-served areas and upstream from the Indianapolis WWTFs. The Stout site is just downstream from a low-head dam on the river and downstream from the Belmont WWTF. Beginning in 2004, an additional site was added to obtain more information on the biology of the White River downstream from the CSO area and just upstream from the Southport WWTF. This site is referred to as the "Tibbs" or "Tibbs-Banta" site in this report, and it is adjacent to and directly north of the Southport WWTF.

The Tibbs site is at river mile 222.5 and has a drainage area of $1,920 \mathrm{mi}^{2}$. Benthic invertebrates were collected at the upstream end of an extensive gravel bar. Fish were collected along a 500-meter $(\mathrm{m})$ reach that extended from a riffle at the upstream end of the gravel bar and comprised riffles, runs, and one or two deeper pools.

Six sites were on tributaries in and around Marion County (fig. 1). Two of those sites (Buck Creek and Williams Creek) are outside the CSO-served area. The remaining four tributary sites all receive input from CSOs, although the number and volume of such overflows varies by drainage basin (Voelker, 2004). Pleasant Run has the most CSOs (49), followed by Fall Creek (27), Pogues Run (24), and Eagle Creek (5). Pogues Run is the only site with periods of no flow. In 2004, a wetland was completed in the headwaters of Pogues Run to help mediate the effects of CSOs. 


\section{Benthic Invertebrates}

Benthic invertebrates are used to assess biological integrity because they occupy all stream habitats and have a wide range of feeding preferences. They are also good indicators of overall stream quality because they respond to environmental stresses and are not very mobile. Benthic invertebrates occupy intermediate levels of the aquatic food chain and are a major food source for fish and other aquatic life. They are an excellent indicator of biological integrity in aquatic environments because much is known about their life cycles and tolerance to environmental stresses (Koryak and Stafford, 2002; Ohio Environmental Protection Agency, 1989; Reece and Richardson, 2000).

Benthic invertebrates were collected twice a year during periods of relatively stable low streamflow. Samples were collected in the spring (May through June) and again in the late summer/early fall (September through October). Higher than normal discharges on occasion resulted in delayed sampling so that benthic-invertebrate samples could be collected during periods of relatively steady-state low flow. Three individual samples were collected from habitats where the greatest diversity and abundance of invertebrates was expected. Such habitats are usually riffle sections; however, those sections were not available at all sites, so the next best available habitat was sampled. Benthic invertebrates were collected at each site by using a Surber sampler with a 0.0929-square-meter sample grid and a collection-net mesh opening of 210 micrometers $(\mu \mathrm{m})$. Sampling followed the guidelines set forth in Britton and Greeson (1988) and described in Voelker (2004).

Benthic invertebrates were preserved and sent to a laboratory (Pennington and Associates, Cookeville, Tennessee) where they were identified to the lowest possible taxonomygenerally genus and species. For this study, ambiguous taxa were those that could not be identified to species, and these were counted as a distinct taxon only if there were no reported individuals from the next highest taxonomic level. Possible reasons for the inability to classify an organism to species may be that the organism was damaged in the sampling process or that the life stage could not be classified to a lower taxon. The laboratory also calculated the number of organisms in the sample, the number of taxa, and HBI for each set of three samples. The results of the three individual samples were combined to determine the EPT Index, HBI, and ICI scores for each sampling round at each site. The HBI was calculated from pollution-tolerance values assigned to benthic-invertebrate taxa, using the number of individuals in each family and a tolerance value for that family, summing the products, and dividing that sum by the total number of arthropods in the sample. Scores can range from 0 to 10 , and they increase with presumed organic contamination. The ICI was developed to provide a descriptive statistic that could be used to compare sites within a study area (Ohio Environmental Protection Agency, 1987). The ICI consists of 10 structural and functional community metrics that describe the benthic-invertebrate community sampled. The metrics include total number of taxa present; number of mayfly (Ephemeroptera), caddisfly (Trichoptera), and Dipteran taxa present; percent mayfly (Ephemeroptera), caddisfly (Trichoptera), Tribe Tanytarsini midge composition, other Dipteran and non-insect composition, and tolerant organisms; and total number of EPT taxa.

\section{Fish}

Fish communities were sampled because, although they are more mobile than benthic invertebrates, they typically remain in a particular stream reach for their entire life cycle. Similar to benthic invertebrates, fish also are sensitive to water-quality conditions, with limited options to escape stressors in their environment. Because of these factors, fish-community data also are a reliable indicator of long-term water-quality conditions in a stream.

Fish communities were sampled during the summer in 2006 and 2008 in accordance with guidelines established by the USGS National Water-Quality Assessment (NAWQA) Program (Meador and others, 1993) and the Indiana Water Science Center quality-assurance plan for fish taxonomic data (Brian Caskey, U.S. Geological Survey, written commun., 2011). On the White River, stream reaches of $500 \mathrm{~m}$ were sampled, and on the tributaries, reaches were $150 \mathrm{~m}$ in length. The sampled stream-reach lengths were set as close to these distances as possible, and samples were collected as much as was practical between riffle cross sections, because riffles serve as natural barriers to fish migration out of a given reach. Fish were collected by using pulsed direct-current electrofishing techniques. Specially designed electrofishing boats were used at nonwadeable sites (all White River sites), and backpack or tote-barge mounted equipment was used at wadeable stream sites (all tributaries). Two passes were made through each site to sample the fish community. After each pass was completed, the collected fish were identified to species, measured, and weighed, and any external anomalies were identified and recorded. Voucher specimens were collected to provide a reference for fish taxonomic classifications made by this study. Voucher specimens either were collected photographically or were physically preserved in a 10-percent formalin solution and returned to the USGS laboratory. Taxonomic nomenclature followed that established by Nelson and others (2004).

Fish data were analyzed by using the Indiana Index of Biotic Integrity (IBI) developed by Simon and Dufour (1997) for sites in the Eastern Cornbelt Plains Ecoregion. The 12 metrics used in the IBI are described by Simon and Dufour (1997) specifically for use in Indiana. These metrics are based on those developed by the State of Ohio (Ohio Environmental Protection Agency, 1989). The IBI combines measures of fish-community structure, function, and health, and scores are assigned to the sampled fish community relative to a reference fish community. 


\section{Streambed-Sediment Chemistry}

Streambed sediments were collected in accordance with guidelines set forth by Shelton and Capel (1994) and Radtke (2005). Samples were collected during low streamflow conditions in the summers of 2005 and 2007. Polypropylene scoops were used to collect the topmost layer of wetted fine sediments. These were placed into a glass jar for transport back to the USGS laboratory in Indianapolis for processing. In the Indianapolis laboratory, these samples were split and sieved into two components: a $63-\mu \mathrm{m}$ fraction for analyzing trace elements, and a 2-millimeter fraction for analyzing organic constituents. The samples were then shipped to the USGS National Water Quality Laboratory (NWQL) in Denver, Colorado, for analysis.

Sediment-quality guidelines were developed in Canada (Canadian Council of Ministers of the Environment, 1995) and were further supported by MacDonald and others (2000). Two assessment values - the threshold effect level (TEL) and the probable effect level (PEL) - are presented in this text for 19 compounds detected in the study area.

\section{Condition of Benthic-Invertebrate Communities}

During this study, 233 distinct benthic-invertebrate taxa were identified. A summary list of those taxa is presented in table 3 (at back of report). A complete list of all benthic-invertebrate data for each sample is presented in appendix 1 .

Species richness (number of taxa) at the sites ranged from 17 to 60 distinct benthic-invertebrate taxa identified during a single sampling event. Median diversity among all the samples collected at sites along the White River generally decreased downstream, with the upstream sites Nora (41 taxa) and Morris (43 taxa) having the highest number of taxa and Waverly having the lowest (28 taxa) (fig. 2). On the tributaries, Buck Creek (one of the CSO control sites) had the highest median diversity (52 taxa), and Pleasant Run had the lowest (32 taxa). Williams Creek (the other CSO control site) had moderate numbers of taxa (38), an indication that other stressors are affecting this stream.

Dipterans were the dominant taxa found at all sites. Although generally pollution tolerant, the Dipterans also tend to have the greatest range of pollution tolerance among benthic invertebrates (Ohio Environmental Protection Agency, 1989).

Among the White River sites, Dipterans composed from about 21 to 63 percent of the samples; at the tributary sites, they composed from 42 to 86 percent of the samples. Although the
Diptera were the predominant taxa present, other taxa from the class Insecta often made up a considerable portion of the sample. Those taxa were usually from the primarily pollutionintolerant orders of Ephemeroptera and Tricoptera. Only at the Harding site on the White River were the pollution-tolerant Ostracoda crustaceans at times the overwhelmingly dominant taxa.

The highest (Tibbs, at 22,060/ $\mathrm{m}^{2}$ ) and lowest (Wicker, at $\left.8,154 / \mathrm{m}^{2}\right)$ median density of benthic-invertebrate organisms were found on the White River (fig. 3). Of the tributary sites, Fall Creek had the highest density at $19,081 / \mathrm{m}^{2}$, and Pogues Run had the lowest density at $9,109 / \mathrm{m}^{2}$.

\section{Benthic-Invertebrate Indexes}

Three benthic-invertebrate indexes were calculated to describe the benthic-invertebrate composition at sites. These include the Ephemeroptera, Plecoptera, Trichoptera (EPT) Index, Hilsenhoff Biotic Index (HBI), and the Invertebrate Community Index (ICI).

\section{Ephemeroptera, Plecoptera, Trichoptera (EPT) Index}

The EPT index for each site was calculated from the sum of the number of taxa in the Ephemeroptera, Plecoptera, and Trichoptera orders. These pollution-intolerant groups reflect improved water-quality conditions as the number of taxa increases.

During the 2003-2008 study period, the EPT scores on the White River ranged from 16 at Nora (November 2003, May 2005, and October 2006) to 2 at Harding (November 2003) and Wicker (May 2004 and May 2005) (table 4). The median scores at the White River sites ranged from 5 to 8 at sites downstream from the CSO influence. The median score was 13 at Nora - the only site on the White River that was upstream from CSOs (fig. 4).

On the tributaries, EPT scores ranged from lows of 2 at Eagle Creek (June 2008), Fall Creek (May 2004), and Pogues Run (May 2005) to 17 at Buck Creek (September 2007) (table 4). The median scores at these sites ranged from 6 at Fall Creek, Pleasant Run, and Pogues Run to 13 at Buck Creek (fig. 4).

The EPT scores indicate that the greatest numbers of these pollution-intolerant organisms are found upstream from, or away from, the combined-sewer areas. Sites directly affected by CSOs or that are in the more urbanized areas have less diversity among these taxa. 


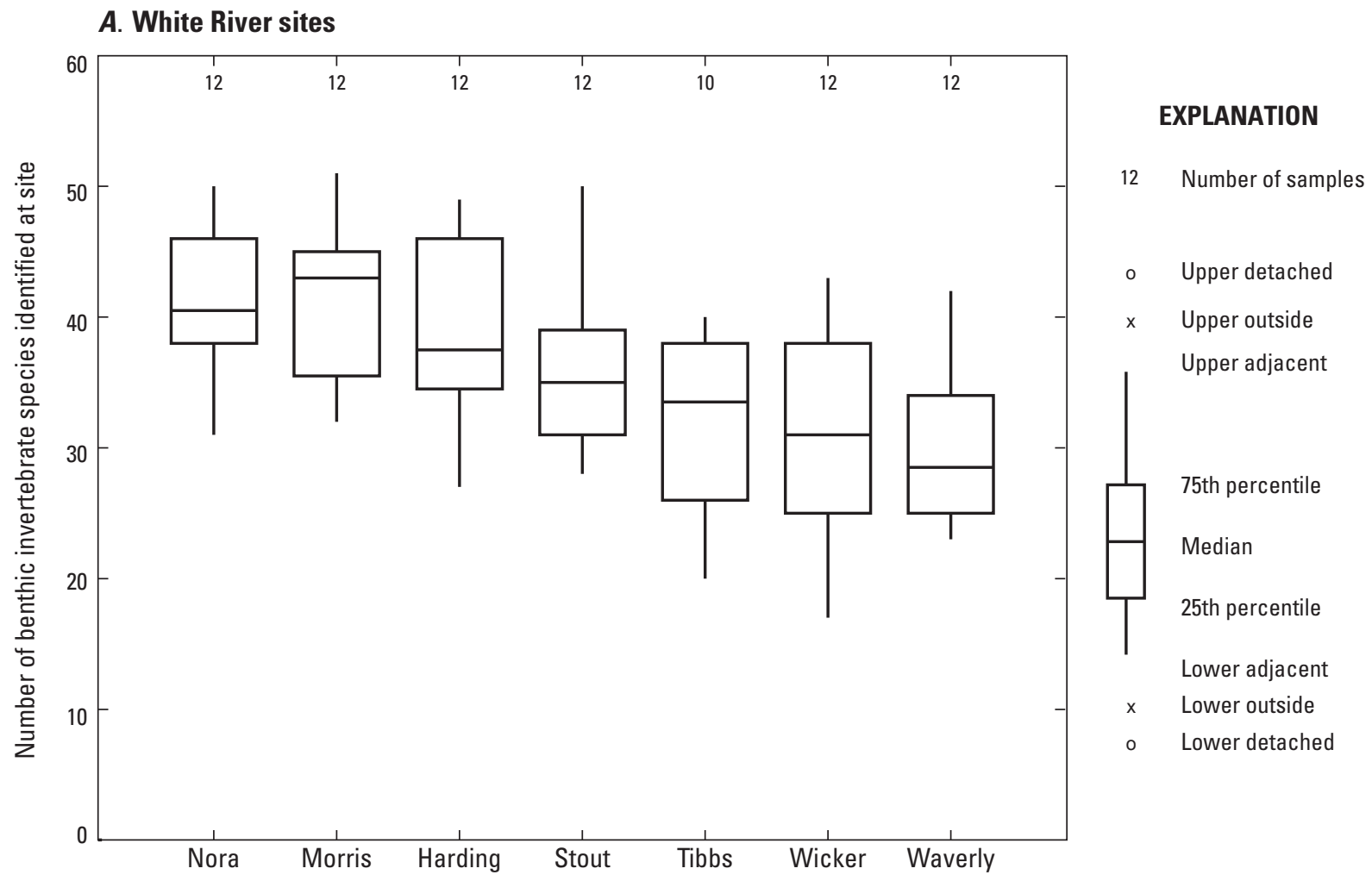

\section{B. Tributary sites}

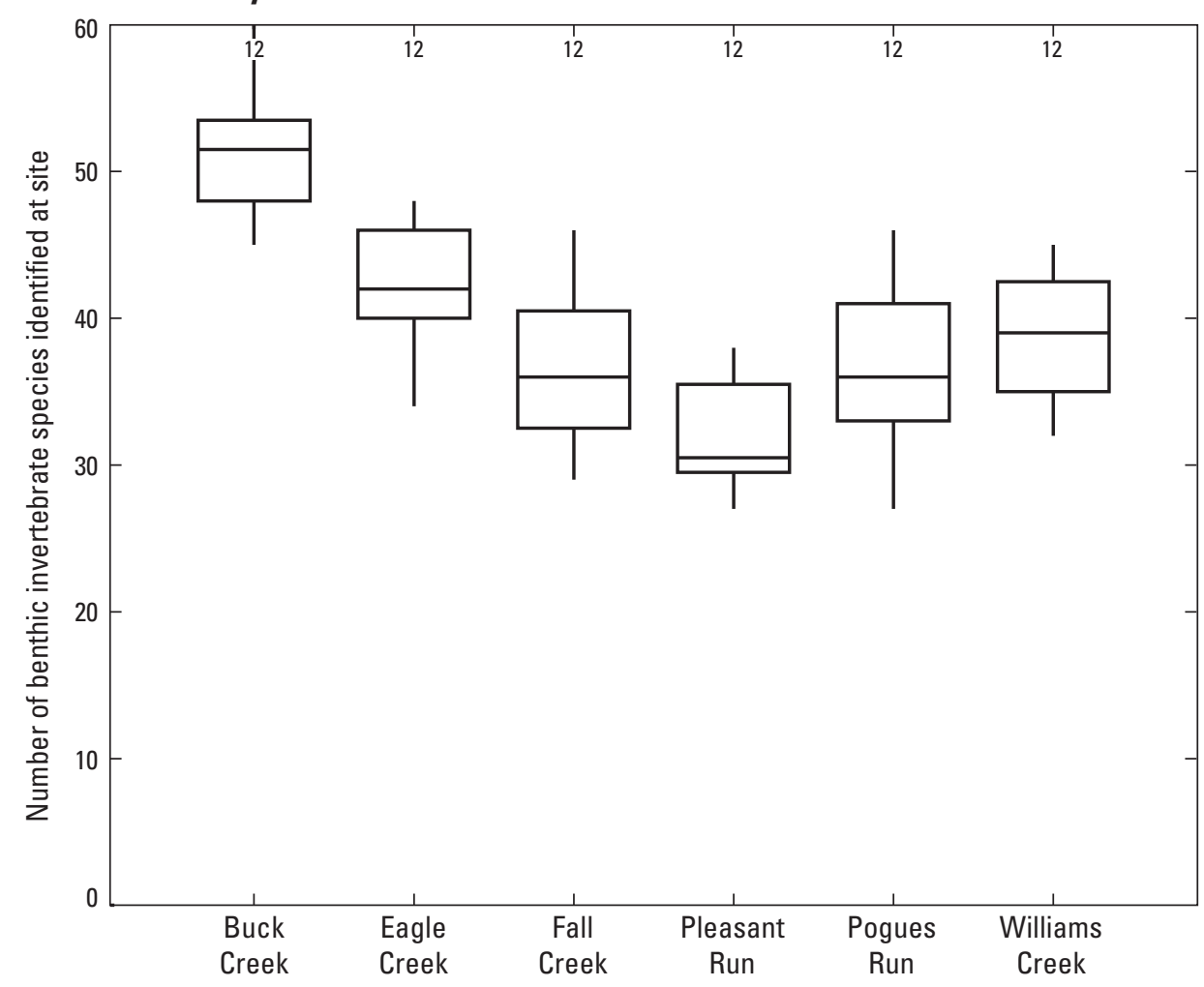

Figure 2. Diversity of the benthic-invertebrate population, 2003-2008. A, Sites on the White River. B, Tributary sites. 

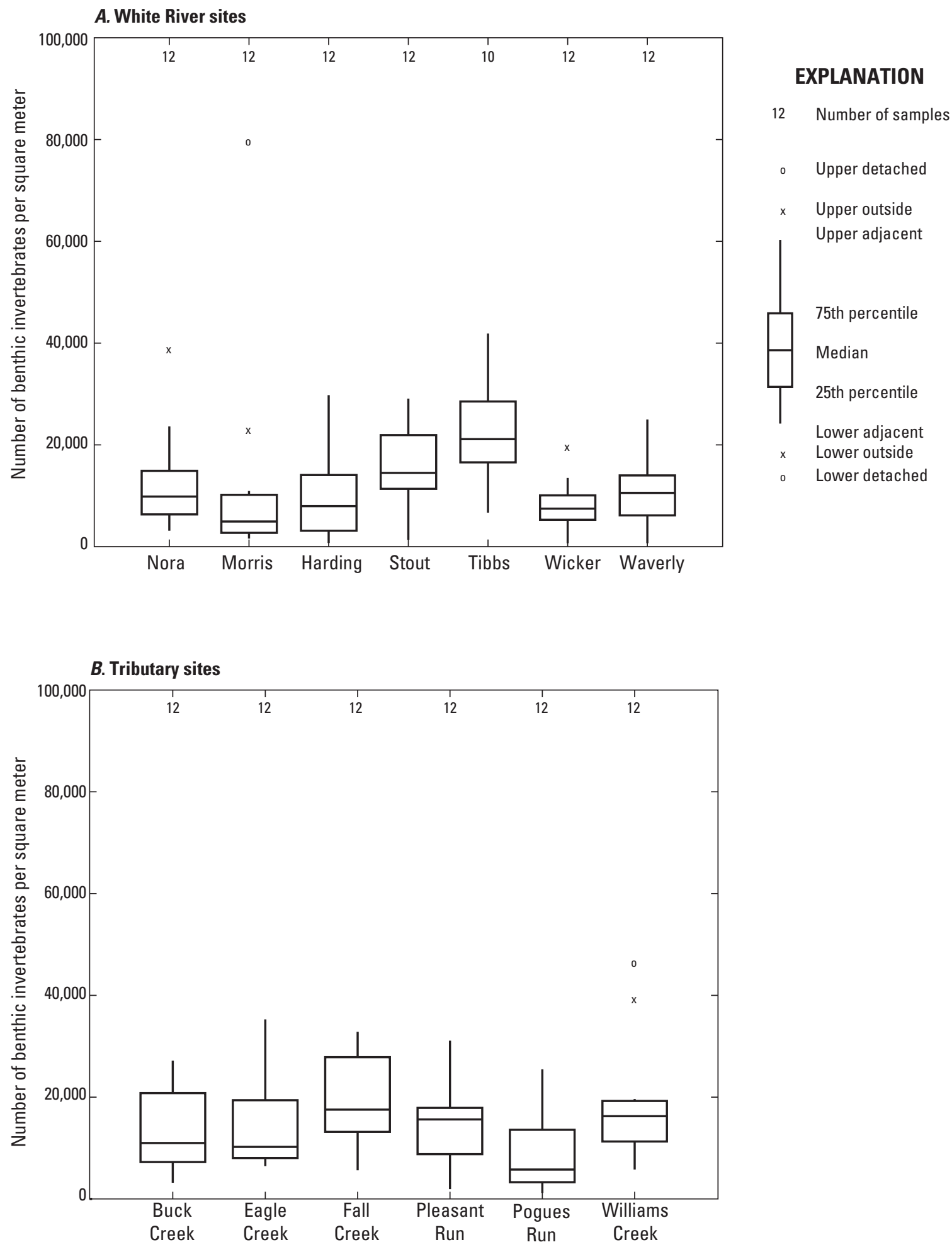

Figure 3. Density of benthic invertebrates, 2003-2008. A, Sites on the White River. $B$, Tributary sites. 
Table 4. Ephemeroptera, Plecoptera, and Trichoptera (EPT) Index scores at all sites in the Indianapolis metropolitan area, 1981-2008.

[--, no sample collected]

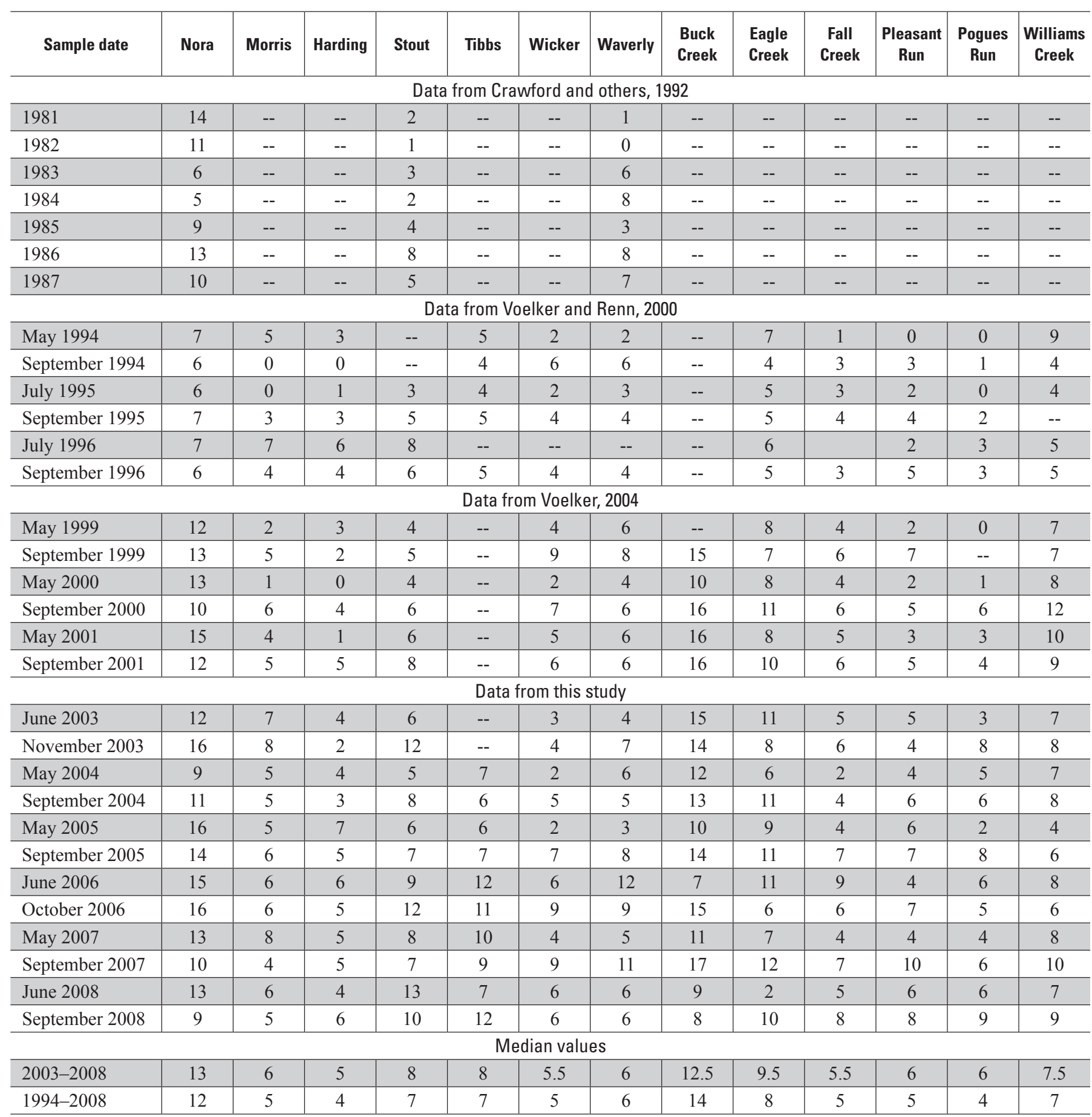



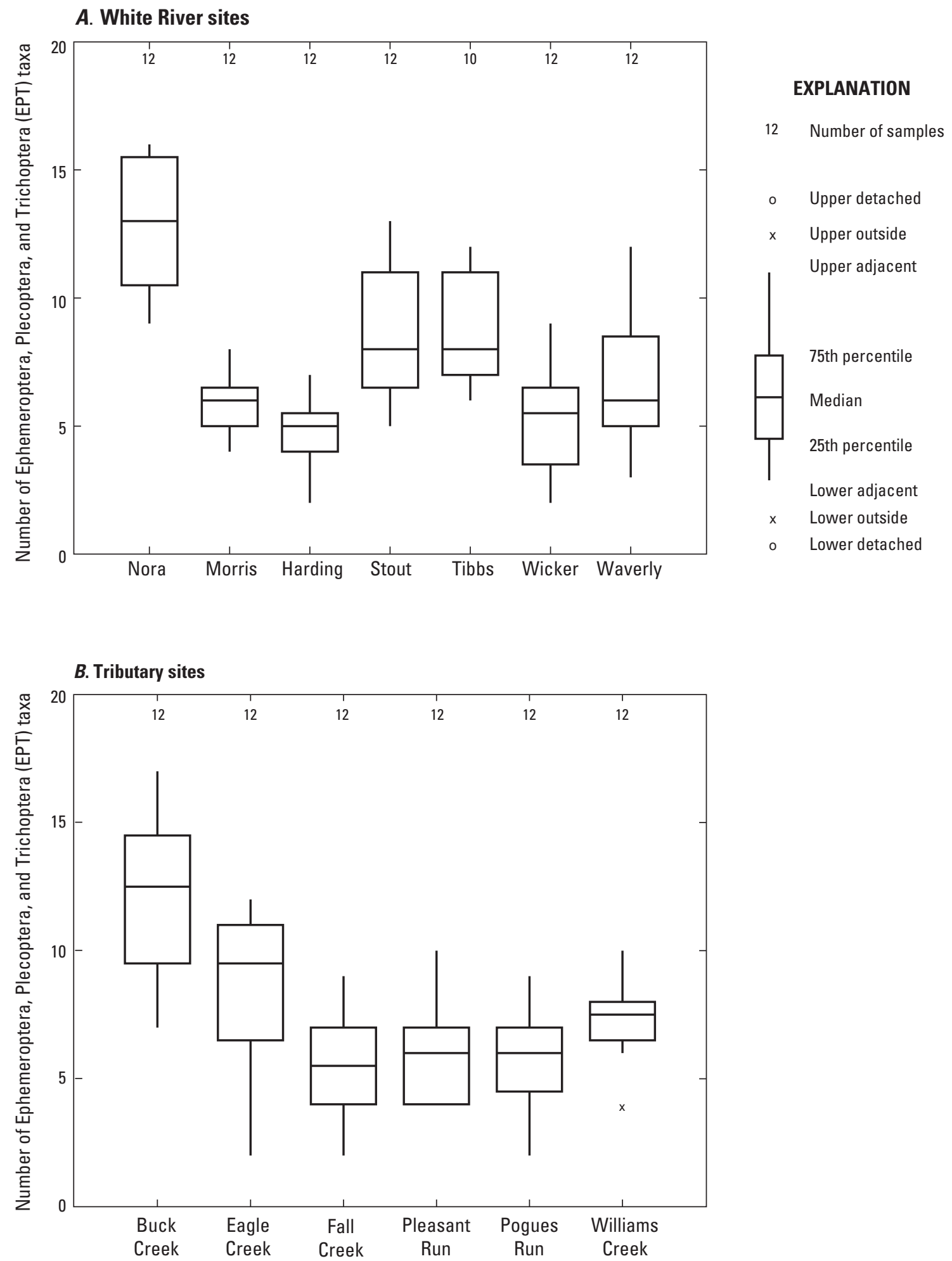

Figure 4. Ephemeroptera, Plecoptera, and Trichoptera (EPT) Index scores, 2003-2008. A, Sites on the White River. $B$, Tributary sites. 


\section{Hilsenhoff Biotic Index (HBI)}

The HBI was developed to assess organic pollution through its effect on benthic-invertebrate populations. HBI scores for individual sampling events were lowest $(4.67$, good) at Nora in June 2006 and highest (9.55, very poor) at Morris in September 2008 for sites on the White River (table 5). Median HBI scores for all samples from sites on the White River ranged from 5.78 (fair) at Nora to 8.00 (poor) at Harding (fig. 5). Median scores at the Nora, Wicker, and Waverly sites all rated "good," indicating some organic pollution present. The HBI scores at the Stout and Tibbs sites rated "fair," indicating fairly significant organic pollution. The median scores for the Morris and Harding sites both rated "fairly poor" indicating significant organic pollution at those sites.

On the tributaries, HBI scores ranged from a low of 4.21 (very good) at Buck Creek (November 2003) to a high of 8.14 (poor) at Pogues Run (May 2004) (table 5). Median scores ranged from 5.84 (fair) at Williams Creek to 7.1 (fairly poor) at Fall Creek during the study period (fig. 5). All other tributary sites also rated "fair," indicating fairly significant organic pollution at those sites.

\section{Invertebrate Community Index (ICI)}

The ICI was developed to use 10 structural and functional metrics to describe the benthic-invertebrate communities. The ICI was developed to compare sites within a study area and is used to identify streams that are biologically impaired. The higher the ICI score, the less impaired the water-quality conditions at that site.

The ICI scores on the White River ranged from a high of 46 at Nora (June 2008) to 12 at Harding (November 2003) and Wicker (May 2004) during the study period (table 6). The median scores at the White River sites ranged from 35 at Nora to 22 at both Harding and Wicker. As is evident from figure 6, ICI scores were lowest at the Morris, Harding, Wicker, and Waverly sites, which are all downstream from the CSO area. The Stout and Wicker sites have higher ICI scores than the other sites downstream from the CSO area, but none of these sites score as high as the Nora site upstream from the CSO influence.

For sites on the tributary streams, ICI scores ranged from 54 at Buck Creek (September 2004) to 12 at Fall Creek (May 2004) during the study period (table 6). The median scores during the study ranged from 38 (Buck Creek) to 26 (Fall Creek and Pleasant Run) (fig. 6). The remaining sites had median scores from 33 to 35 . All of these tributary scores were higher than for most sites on the White River, with the exception of Fall Creek and Pleasant Run.

These ICI scores also indicate that the best conditions in support of pollution-intolerant benthic-invertebrate communities are at the Nora, Buck Creek, and Williams Creek sites. On the White River, data support the thesis that the most impaired communities are at sites downstream from CSOs and in highly urbanized areas.

\section{Condition of Fish Communities}

During the course of this study, 65 taxa (including 1 hybrid) were collected (tables 7 and 8, at back of report). On the White River, 51 fish species (1 hybrid) were collected (table 7), whereas on the tributaries, 53 fish species were collected (table 8). A complete list of all fish data for each sample is presented in appendix 2 .

On the White River, the number of species identified ranged from 16 at Waverly in 2008 to 27 at Stout in 2008 (table 7). The total number of fish collected at each site ranged from 176 at Harding in 2006 to 710 at Morris in 2008. The Centrarchidae (sunfishes) were 20 percent and the Catostomidae (suckers and buffalo) 12 percent of all fish collected at the White River sites. On the tributaries, the number of species collected ranged from 8 at Pogues Run in 2006 to 34 at Buck Creek in 2008 (table 8). The total number of fish collected ranged from 424 at Eagle Creek in 2006 to 2,345 at Pleasant Run in 2008. Cyprinidae (carps and minnows) made up 30 percent and Centrarchidae made up 12 percent of all fish collected among all the tributary sites in 2006 and 2008.

During the 2008 sampling, sand shiners (Notropis stramineus) and central stonerollers (Campostoma anomalum) dominated the fish communities at several sites: 369 sand shiners were collected at the Tibbs site, representing 60 percent of that sample's population; 714 central stonerollers, or 30 percent of the sample population, were among the Pleasant Run sample. The most dominant species by number identified on the White River were sand shiners (14 percent), longear sunfish (Lepomis megalotis) (9 percent), bluegill (Lepomis macrochirus) (6 percent), spotfin shiners (Cyprinella spiloptera) (5 percent), and northern hog suckers (Hypentelium nigricans) and central stonerollers (4 percent each). Dominant species at the tributary sites were central stonerollers (17 percent), longear sunfish and bluegill (5 percent each), and creek chubs (Semotilus atromaculatus) and sand shiners (4 percent each).

Fish anomalies were identified and recorded while field personnel processed the length and weights of the fish collected. Most anomalies were recorded during the 2006 sampling (table 9). The number of anomalies ranged from zero at Pogues Run to 24 at Stout. During 2008, fish anomalies ranged from a zero at five sites to 13 anomalies at the Nora site. Eroded fins were most often recorded, followed by lesions and ulcers. Fish with leeches and blindness in at least one eye were also more numerous in 2006 than in 2008. 
Table 5. Hilsenhoff Biotic Index (HBI) scores at all sites in the Indianapolis metropolitan area, 1981-2008.

$[--$, no sample collected]

\begin{tabular}{|c|c|c|c|c|c|c|c|c|c|c|c|c|c|}
\hline Sample date & Nora & Morris & Harding & Stout & Tibbs & Wicker & Waverly & $\begin{array}{l}\text { Buck } \\
\text { Creek }\end{array}$ & $\begin{array}{l}\text { Eagle } \\
\text { Creek }\end{array}$ & $\begin{array}{l}\text { Fall } \\
\text { Creek }\end{array}$ & $\begin{array}{c}\text { Pleasant } \\
\text { Run }\end{array}$ & $\begin{array}{l}\text { Pogues } \\
\text { Run }\end{array}$ & $\begin{array}{c}\text { Williams } \\
\text { Creek }\end{array}$ \\
\hline \multicolumn{14}{|c|}{ Data from Crawford and others, 1992} \\
\hline 1982 & 5.99 & -- & -- & 8.41 & -- & -- & 9.88 & -- & -- & -- & -- & -- & -- \\
\hline 1983 & 6.69 & -- & -- & 7.77 & -- & -- & 6.12 & -- & -- & -- & -- & -- & -- \\
\hline 1986 & 5.03 & -- & -- & 5.62 & -- & -- & 5.34 & -- & -- & -- & -- & -- & -- \\
\hline 1987 & 5.69 & -- & -- & 5.06 & -- & -- & 5.3 & -- & -- & -- & -- & -- & -- \\
\hline \multicolumn{14}{|c|}{ Data from Voelker and Renn, 2000} \\
\hline May 1994 & 5.4 & 5.9 & 5.9 & -- & 5.9 & 6 & 6 & -- & 6 & 5.9 & 6 & 6.4 & 5.4 \\
\hline September 1996 & 4.8 & 9.2 & 9.4 & 6.4 & 5.7 & 6.3 & 4.9 & -- & 6.2 & 4.9 & 6.5 & 6.6 & 5.2 \\
\hline \multicolumn{14}{|c|}{ Data from Voelker, 2004} \\
\hline May 1999 & 6.28 & 7.74 & 7.82 & 7.4 & -- & 8.41 & 7.41 & -- & 7.19 & 6.45 & 7.87 & 7.96 & 6.47 \\
\hline September 1999 & 6.08 & 9.5 & 9.59 & 7.01 & -- & 5.56 & 5.9 & 5.2 & 6.92 & 6.63 & 7.28 & -- & 6.35 \\
\hline May 2000 & 6.8 & 6.98 & 7.8 & 7.43 & -- & 7.79 & 7.29 & 6.97 & 6.6 & 7.59 & 7.91 & 7.75 & 6.19 \\
\hline September 2000 & 5.62 & 8.85 & 9.09 & 6.53 & -- & 7.79 & 7.29 & 5.78 & 5.78 & 6.37 & 6.71 & 6.55 & 5.38 \\
\hline May 2001 & 6.09 & 7.93 & 8.04 & 7.1 & -- & 7.41 & 7.17 & 2.86 & 6.88 & 7.25 & 7.24 & 7.89 & 6.33 \\
\hline September 2001 & 4.95 & 8.2 & 8.8 & 5.73 & -- & 5.56 & 5.63 & 5.36 & 5.5 & 5.69 & 7.34 & 6.94 & 5.46 \\
\hline \multicolumn{14}{|c|}{ Data from this study } \\
\hline October 2006 & 5.71 & 6.83 & 8 & 5.65 & 5.57 & 5.65 & 5.79 & 6 & 5.45 & 6.39 & 6.8 & 6.13 & 6.07 \\
\hline May 2007 & 6.12 & 7.87 & 8.62 & 6.59 & 7.79 & 8.19 & 7.19 & 6.88 & 6.83 & 8 & 6.88 & 6.03 & 6.65 \\
\hline September 2007 & 5.38 & 9.11 & 7.18 & 6.38 & 5.53 & 5.45 & 5.19 & 5.26 & 5.33 & 6.56 & 6.14 & 6.33 & 5.05 \\
\hline June 2008 & 5.77 & 7.44 & 6.87 & 5.75 & 6.09 & 6.08 & 6.65 & 5.84 & 5.62 & 5.83 & 4.59 & 5.63 & 5.99 \\
\hline September 2008 & 5.77 & 9.55 & 9.11 & 6.98 & 6.07 & 7.4 & 6.38 & 5.99 & 6.68 & 6.07 & 5.78 & 6.14 & 5.36 \\
\hline \multicolumn{14}{|c|}{ Median values } \\
\hline 2003-2008 & 5.78 & 7.67 & 8.25 & 6.43 & 6.00 & 6.56 & 6.21 & 5.89 & 5.91 & 7.10 & 6.46 & 6.38 & 5.84 \\
\hline 1994-2008 & 5.77 & 7.75 & 8.02 & 6.48 & 5.85 & 6.45 & 5.99 & 5.84 & 6.40 & 6.63 & 6.61 & 6.55 & 5.60 \\
\hline
\end{tabular}


A. White River sites
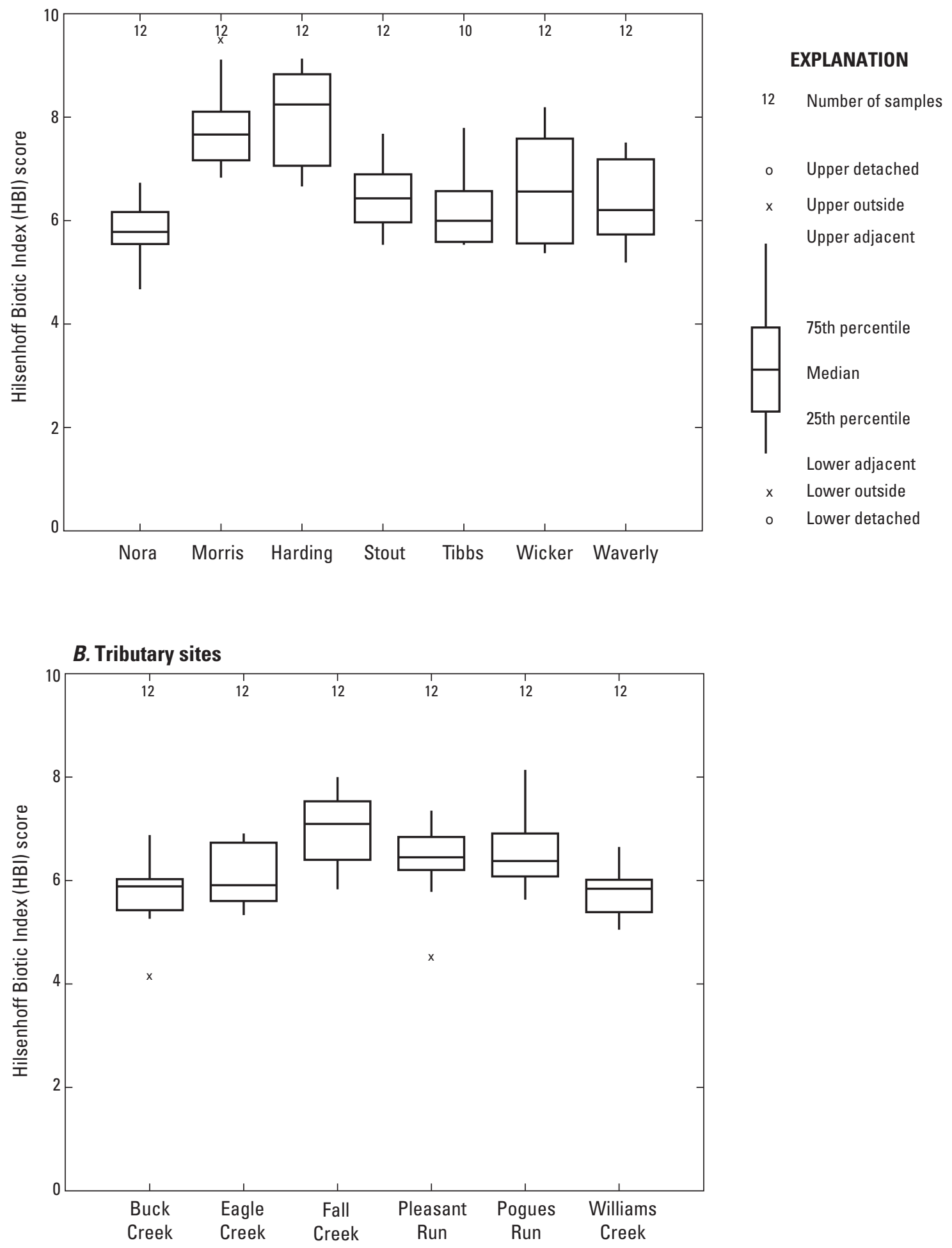

Figure 5. Hilsenhoff Biotic Index (HBI) scores, 2003-2008. A, Sites on the White River. $B$, Tributary sites. 
Table 6. Invertebrate Community Index (ICI) scores at all sites in the Indianapolis metropolitan area, 1999-2008.

$[--$, no sample collected]

\begin{tabular}{|c|c|c|c|c|c|c|c|c|c|c|c|c|c|}
\hline Sample date & Nora & Morris & Harding & Stout & Tibbs & Wicker & Waverly & $\begin{array}{l}\text { Buck } \\
\text { Creek }\end{array}$ & $\begin{array}{l}\text { Eagle } \\
\text { Creek }\end{array}$ & $\begin{array}{c}\text { Fall } \\
\text { Creek }\end{array}$ & $\begin{array}{c}\text { Pleasant } \\
\text { Run }\end{array}$ & $\begin{array}{c}\text { Pogues } \\
\text { Run }\end{array}$ & $\begin{array}{c}\text { Williams } \\
\text { Creek }\end{array}$ \\
\hline \multicolumn{14}{|c|}{ Data from Voelker, 2004} \\
\hline September 1999 & 38 & 22 & 12 & 26 & -- & 30 & 30 & 48 & 22 & 22 & 30 & -- & 36 \\
\hline May 2000 & 36 & 14 & 8 & 18 & -- & 14 & 18 & 30 & 26 & 16 & 10 & 12 & 32 \\
\hline September 2001 & 32 & 22 & 26 & 30 & -- & 26 & 32 & 50 & 38 & 30 & 30 & 32 & 42 \\
\hline \multicolumn{14}{|c|}{ Data from this study } \\
\hline June 2003 & 34 & 24 & 16 & 24 & -- & 16 & 18 & 36 & 34 & 26 & 24 & 22 & 40 \\
\hline November 2003 & 42 & 26 & 12 & 32 & -- & 16 & 24 & 42 & 34 & 30 & 26 & 42 & 46 \\
\hline June 2006 & 42 & 22 & 26 & 36 & 32 & 22 & 30 & 34 & 34 & 30 & 24 & 32 & 44 \\
\hline October 2006 & 42 & 22 & 22 & 42 & 36 & 34 & 32 & 40 & 28 & 24 & 30 & 38 & 28 \\
\hline May 2007 & 34 & 28 & 22 & 28 & 32 & 34 & 22 & 20 & 30 & 20 & 26 & 34 & 38 \\
\hline September 2007 & 28 & 18 & 26 & 28 & 26 & 34 & 34 & 30 & 40 & 30 & 40 & 34 & 42 \\
\hline June 2008 & 46 & 30 & 20 & 36 & 24 & 32 & 24 & 26 & 20 & 20 & 26 & 32 & 32 \\
\hline September 2008 & 34 & 26 & 30 & 30 & 34 & 46 & 24 & 22 & 32 & 34 & 46 & 46 & 40 \\
\hline \multicolumn{14}{|c|}{ Median values } \\
\hline 2003-2008 & 35 & 23 & 22 & 30 & 30 & 26 & 24 & 35 & 33 & 25 & 26 & 34 & 36 \\
\hline 1994-2008 & 35 & 22 & 21 & 29 & 30 & 26 & 24 & 41 & 32 & 23 & 26 & 34 & 36 \\
\hline
\end{tabular}



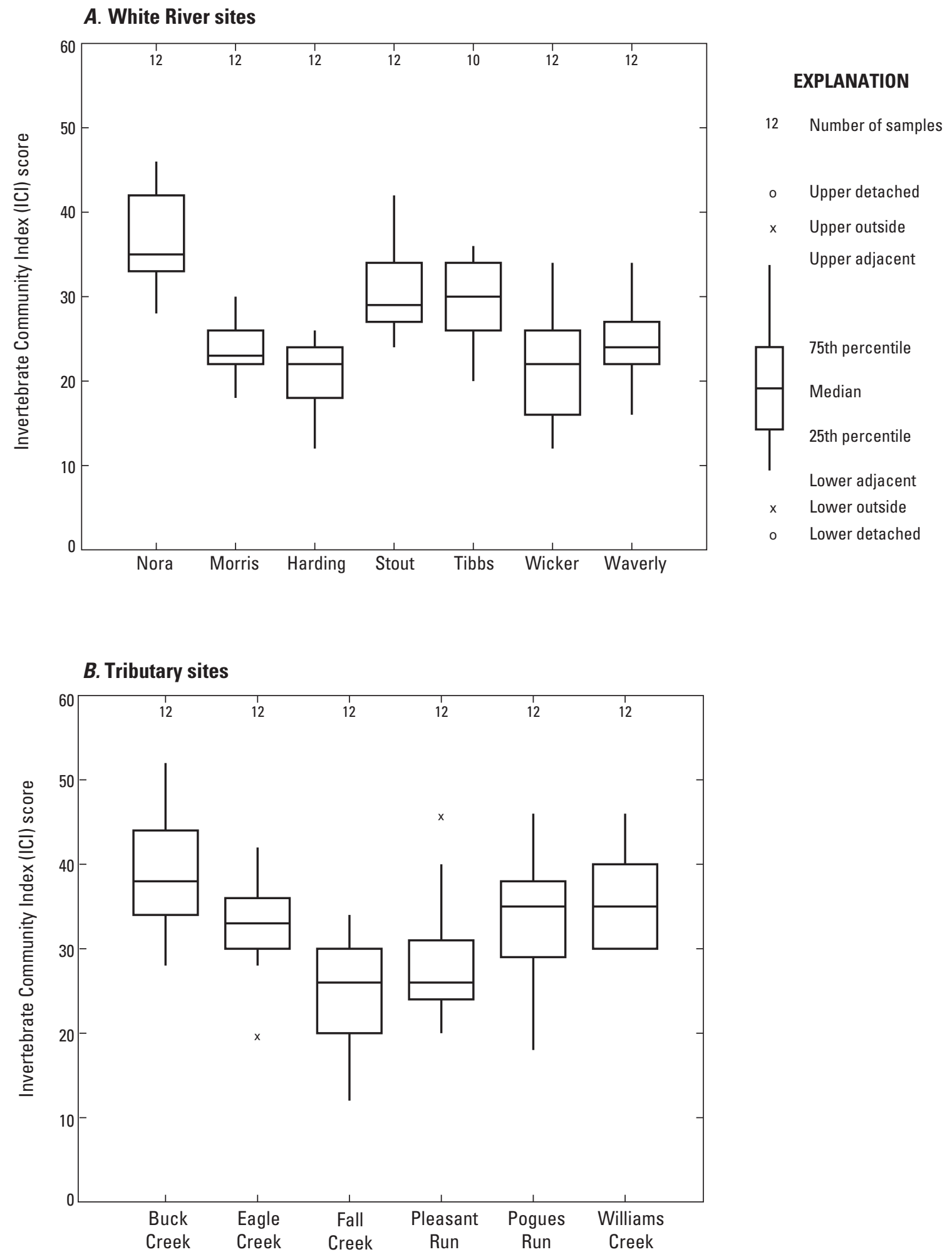

Figure 6. Invertebrate Community Index (ICI) scores, 2003-2008. A, Sites on the White River. B, Tributary sites. 
Table 9. Fish anomalies observed at all sites in the Indianapolis metropolitan area during 2006 and 2008.

\begin{tabular}{|c|c|c|c|c|c|c|c|c|c|c|c|c|c|}
\hline Sampling site & $\begin{array}{c}\text { Deformi- } \\
\text { ties }\end{array}$ & $\begin{array}{l}\text { Eroded } \\
\text { fins }\end{array}$ & $\begin{array}{c}\text { Lesions } \\
\text { and } \\
\text { ulcers }\end{array}$ & Tumors & $\begin{array}{l}\text { Anchor } \\
\text { worms }\end{array}$ & $\begin{array}{c}\text { Black } \\
\text { spot }\end{array}$ & Leeches & Fungus & $\begin{array}{l}\text { White } \\
\text { spot }\end{array}$ & Blind & $\begin{array}{l}\text { Para- } \\
\text { sites }\end{array}$ & Popeye & Total \\
\hline \multicolumn{14}{|c|}{2006} \\
\hline Nora & 1 & 1 & 2 & 0 & 0 & 0 & 0 & 0 & 0 & 0 & 0 & 0 & 4 \\
\hline Morris & 1 & 2 & 0 & 0 & 0 & 0 & 0 & 0 & 0 & 1 & 0 & 0 & 4 \\
\hline Harding & 1 & 0 & 0 & 1 & 0 & 0 & 0 & 0 & 0 & 1 & 0 & 0 & 3 \\
\hline Stout & 0 & 6 & 6 & 0 & 0 & 0 & 9 & 0 & 0 & 3 & 0 & 0 & 24 \\
\hline Tibbs & 0 & 5 & 1 & 0 & 0 & 0 & 0 & 0 & 0 & 1 & 0 & 0 & 7 \\
\hline Wicker & 0 & 1 & 0 & 0 & 0 & 0 & 0 & 0 & 0 & 0 & 0 & 0 & 1 \\
\hline Waverly & 0 & 3 & 2 & 0 & 0 & 0 & 0 & 0 & 0 & 1 & 0 & 0 & 6 \\
\hline Buck Creek & 0 & 1 & 1 & 0 & 0 & 0 & 1 & 0 & 0 & 0 & 0 & 0 & 3 \\
\hline Eagle Creek & 0 & 1 & 0 & 0 & 0 & 0 & 0 & 0 & 0 & 0 & 0 & 0 & 1 \\
\hline Fall Creek & 0 & 0 & 0 & 0 & 0 & 0 & 0 & 0 & 0 & 0 & 0 & 1 & 1 \\
\hline Pleasant Run & 0 & 1 & 3 & 0 & 0 & 0 & 0 & 0 & 0 & 0 & 0 & 0 & 4 \\
\hline Pogues Run & 0 & 0 & 0 & 0 & 0 & 0 & 0 & 0 & 0 & 0 & 0 & 0 & 0 \\
\hline Williams Creek & 0 & 1 & 0 & 0 & 0 & 0 & 0 & 0 & 0 & 0 & 0 & 0 & 1 \\
\hline Total & 3 & 22 & 15 & 1 & 0 & 0 & 10 & 0 & 0 & 7 & 0 & 1 & 59 \\
\hline \multicolumn{14}{|c|}{2008} \\
\hline Nora & 0 & 3 & 5 & 0 & 0 & 0 & 3 & 0 & 0 & 1 & 1 & 0 & 13 \\
\hline Morris & 0 & 0 & 1 & 0 & 0 & 0 & 0 & 0 & 0 & 0 & 0 & 0 & 1 \\
\hline Harding & 0 & 4 & 1 & 0 & 0 & 0 & 0 & 0 & 0 & 1 & 0 & 0 & 6 \\
\hline Stout & 0 & 1 & 0 & 0 & 0 & 0 & 0 & 0 & 0 & 0 & 0 & 1 & 2 \\
\hline Tibbs & 0 & 0 & 0 & 0 & 0 & 0 & 0 & 0 & 0 & 0 & 0 & 1 & 1 \\
\hline Wicker & 0 & 0 & 1 & 0 & 0 & 0 & 0 & 0 & 0 & 0 & 0 & 0 & 1 \\
\hline Waverly & 0 & 1 & 0 & 0 & 0 & 1 & 0 & 0 & 0 & 0 & 0 & 0 & 2 \\
\hline Buck Creek & 0 & 0 & 0 & 0 & 0 & 0 & 0 & 0 & 0 & 0 & 0 & 0 & 0 \\
\hline Eagle Creek & 0 & 0 & 0 & 0 & 0 & 0 & 0 & 0 & 0 & 0 & 0 & 0 & 0 \\
\hline Fall Creek & 0 & 0 & 0 & 0 & 0 & 0 & 0 & 0 & 0 & 0 & 0 & 0 & 0 \\
\hline Pleasant Run & 0 & 0 & 0 & 0 & 0 & 1 & 0 & 0 & 0 & 0 & 0 & 0 & 1 \\
\hline Pogues Run & 0 & 0 & 0 & 0 & 0 & 0 & 0 & 0 & 0 & 0 & 0 & 0 & 0 \\
\hline Williams Creek & 0 & 0 & 0 & 0 & 0 & 0 & 0 & 0 & 0 & 0 & 0 & 0 & 0 \\
\hline Total & 0 & 9 & 8 & 0 & 0 & 2 & 3 & 0 & 0 & 2 & 1 & 2 & 27 \\
\hline
\end{tabular}




\section{Index of Biotic Integrity (IBI)}

The IBI incorporates various metrics relating to species richness, composition, presence/absence of indicator species, trophic and reproductive functions, and overall abundance and/or individual conditions. Scores for each metric are combined; the higher the resultant score, the more robust the fish community.

IBI scores in the White River ranged from 20 (very poor) at Harding to 44 (fair) at Wicker during 2006 and from 34 (poor) at Waverly to 52 (good) at Morris during 2008 (table 10). White River IBIs at individual sites increased from 2006 to 2008, indicating that the condition of the fish community had improved (fig. 7).

Tributary IBI scores ranged from 26 (very poor) at Pogues Run to 52 (good) at Buck Creek and Pleasant Run during 2006 (table 10). During 2008, IBI scores ranged from 26 (very poor) at Pogues Run to 52 (good) at Williams Creek. There was no consistent pattern in IBI scores between the two sampling periods at the tributary sites (fig. 7). IBI scores at Buck Creek and Fall Creek decreased slightly, those at Pogues Run remained the same, and those at Eagle Creek and Williams Creek increased.

\section{Streambed-Sediment Chemistry}

Streambed-sediment samples were collected during extended low-flow periods in early August 2005 and late July 2007; data are presented in appendix 3. Physical waterquality parameters (table 3-1) were measured at each site, and the sediments were analyzed for carbon species (table 3-2), chlorinated pesticides (table 3-3), organophosphate pesticides (table 3-4), trace metals (table 3-5), and semivolatile organic compounds (SVOCs) (table 3-6).

Sediment-quality guidelines for the protection of aquatic life, along with the number of sites at which those guidelines were exceeded, are listed in table 11. The TEL is a concentration below which effects on aquatic life occur rarely, and the PEL is a concentration above which effects on aquatic life occur frequently.
Figure 8 shows the number of sites at which selected chlorinated pesticides were detected. This includes the number of sites where the compound was determined to be present; however, a concentration may have been too low to be quantifiable. Among the most frequently detected chlorinated pesticides were trans-nonachlor, cis-chlordane, dieldrin, trans-chlordane, and PCBs. Of the 33 chlorinated pesticides analyzed for, 9 were detected in 2005 and 12 were detected in 2007.

Only three organophosphate pesticides were detected in the streambed-sediment samples (fig. 9). Chlorpyrifos, a broad-spectrum organophosphate insecticide originally used to kill mosquitoes, was detected at eight sites in 2005. Diazinon, an insecticide used to control cockroaches, silverfish, ants, and fleas in residential, non-food buildings, was detected at four sites during 2005. Ethoprophos, a soil insecticide and nematocide, was detected at three sites and only during the 2007 sampling.

Numerous SVOCs were detected in the streambed sediments collected in both 2005 and 2007 (figs. 10 and 11). Similar results for the two sampling periods showed that more than 30 of these compounds were detected at more than half of the sites sampled. Of the 69 SVOCs analyzed for, 35 were quantified in 2005 along with an addition 6 that were detected but not quantified; in 2007, 30 were quantified and an additional 13 were detected but not quantifiable. In general, the Buck Creek site had the lowest number of detectable SVOCs, as well as the lowest concentrations of these compounds in the streambed sediments (table 3-6). The Harding site on the White River had the highest concentrations of these compounds among all the sites in the study area.

SVOCs detected at every site during both sample periods include nitrobenzene-d5, 2-fluorobiphenyl, fluoranthene, phenanthrene, pyrene, and terphenyl-d14. Most of these compounds are produced by the combustion of hydrocarbon fuels and organic materials (Verschueren, 1983). Several are also characteristic of coal-tar-based parking lot sealcoat (Mahler and Van Metre, 2011), commonly found in metropolitan areas. 
Table 10. Index of Biotic Integrity (IBI) scores at all sites in the Indianapolis metropolitan area, 2006 and 2008.

\begin{tabular}{|c|c|c|c|c|}
\hline Sampling site & 2006 IBI score & Habitat status & 2008 IBI score & Habitat status \\
\hline \multicolumn{5}{|c|}{ White River sites } \\
\hline Nora & 38 & Poor to fair & 46 & Fair to good \\
\hline Morris & 32 & Poor & 52 & Good \\
\hline Harding & 20 & Very poor & 36 & Poor to fair \\
\hline Stout & 42 & Fair & 46 & Fair to good \\
\hline Tibbs & 40 & Fair & 42 & Fair \\
\hline Wicker & 44 & Fair & 46 & Fair to good \\
\hline Waverly & 30 & Poor & 34 & Poor \\
\hline \multicolumn{5}{|c|}{ Tributary sites } \\
\hline Buck Creek & 52 & Good & 50 & Good \\
\hline Eagle Creek & 40 & Fair & 44 & Fair \\
\hline Fall Creek & 52 & Good & 50 & Good \\
\hline Pleasant Run & 40 & Fair & 44 & Fair \\
\hline Pogues Run & 26 & Very poor to poor & 26 & Very poor to poor \\
\hline Williams Creek & 44 & Fair & 52 & Good \\
\hline
\end{tabular}

\section{A. White River sites}

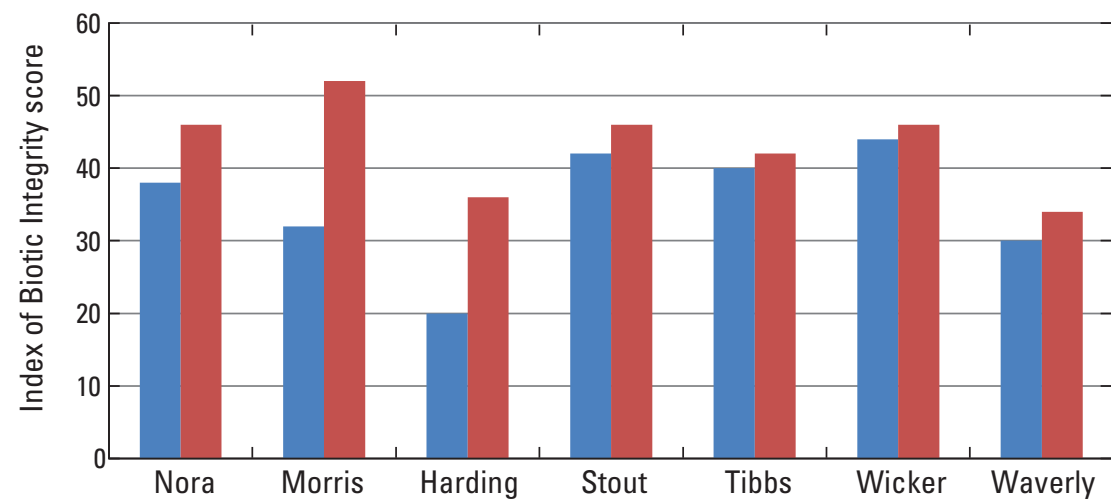

EXPLANATION

2006

— 2008

Figure 7. Index of Biotic Integrity (IBI) scores, 2006 and 2008. $A$, Sites on the White River. $B$, Tributary sites.

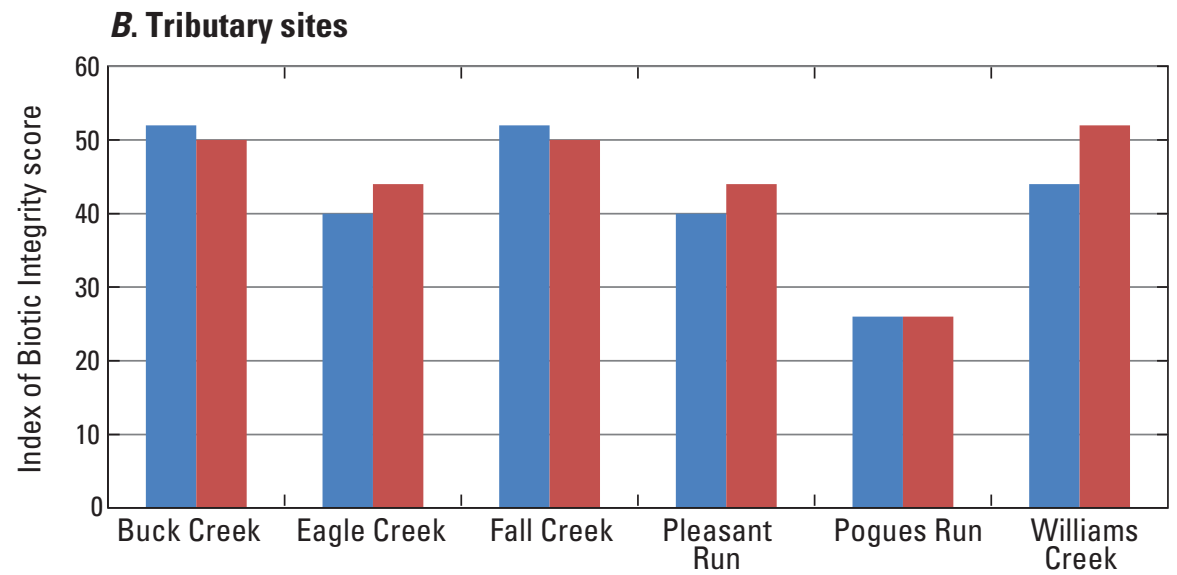


Table 11. Freshwater-sediment Threshold Effect and Probable Effect Levels for the protection of aquatic life (modified from Canadian Council of Ministers of the Environment, 1995).

\begin{tabular}{|c|c|c|c|c|c|}
\hline Chemical constituent & $\begin{array}{l}\text { Threshold } \\
\text { Effect Level }^{1} \\
\text { (TEL) }\end{array}$ & $\begin{array}{l}\text { Number of } \\
\text { sites where } \\
\text { TEL exceeded }\end{array}$ & $\begin{array}{c}\text { Probable } \\
\text { Effect Level }^{2} \\
\text { (PEL) }\end{array}$ & $\begin{array}{l}\text { Number of } \\
\text { sites where } \\
\text { PEL exceeded }\end{array}$ & $\begin{array}{c}\text { Observed } \\
\text { range in } \\
\text { concentrations }\end{array}$ \\
\hline \multicolumn{6}{|c|}{ Metals, in micrograms per gram } \\
\hline Arsenic & 5.9 & 13 & 17 & 2 & $7.7-21$ \\
\hline Cadmium & 0.596 & 13 & 3.53 & 2 & $0.5-6.7$ \\
\hline Chromium & 37.3 & 13 & 90 & 4 & $42-160$ \\
\hline Copper & 35.7 & 13 & 197 & 0 & $29-150$ \\
\hline Lead & 35 & 11 & 91.3 & 8 & $21-190$ \\
\hline Mercury & 0.174 & 9 & 0.486 & 2 & $0.05-1.16$ \\
\hline Nickel & 18 & 13 & 35.9 & 8 & $22-55$ \\
\hline Zinc & 123 & 13 & 315 & 4 & $110-480$ \\
\hline \multicolumn{6}{|c|}{ Pesticides, in micrograms per kilogram } \\
\hline Chlordane & 4.5 & 2 & 8.9 & 0 & $<1-7$ \\
\hline$p, p^{\prime}-\mathrm{DDD}$ & 3.54 & 2 & 8.51 & 0 & $<1-5$ \\
\hline$p, p^{\prime}-\mathrm{DDE}$ & 1.42 & 1 & 6.75 & 0 & $<1-4$ \\
\hline Dieldrin & 2.85 & 2 & 6.67 & 0 & $<1-4$ \\
\hline \multicolumn{6}{|c|}{ Miscellaneous organics, in micrograms per kilogram } \\
\hline PCB's, total & 34.1 & 7 & 277 & 1 & $30-440$ \\
\hline \multicolumn{6}{|c|}{ Semivolatile organic compounds, in micrograms per kilogram } \\
\hline Benzo[a]anthracene & 31.7 & 13 & 385 & 8 & $<50-2,600$ \\
\hline Benzo $[a]$ pyrene & 31.9 & 13 & 782 & 2 & $<50-2,800$ \\
\hline Chrysene & 57.1 & 13 & 862 & 2 & $<50-3,200$ \\
\hline Fluoranthene & 111 & 13 & 2,355 & 1 & $33-4,800$ \\
\hline Phenanthrene & 41.9 & 12 & 515 & 7 & $21-2,200$ \\
\hline Pyrene & 53 & 13 & 875 & 8 & $29-4,100$ \\
\hline
\end{tabular}

${ }^{1}$ Threshold Effect Level (TEL): the concentration below which adverse effects on aquatic life occur rarely.

${ }^{2}$ Probable Effect Level (PEL): the concentration above which adverse effects are predicted to occur frequently. 


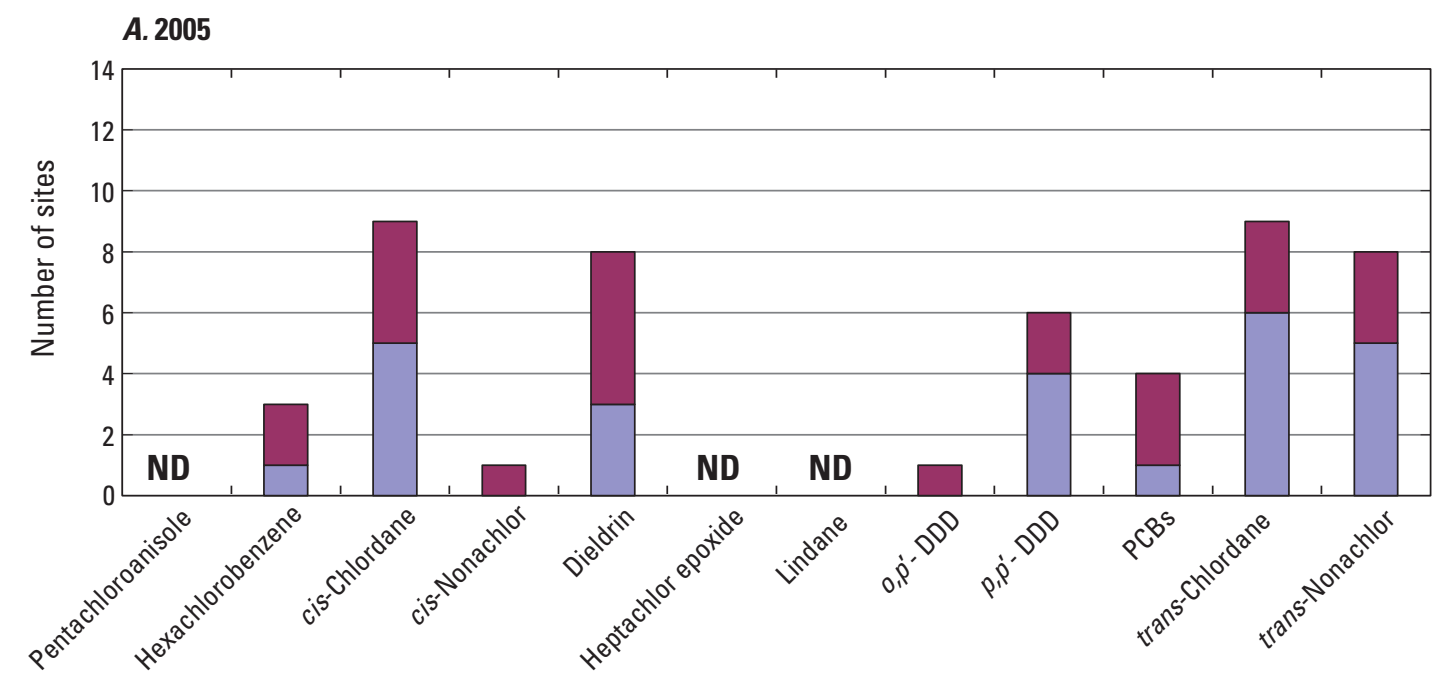

\section{EXPLANATION}

$\square$ Number above detection limit

- Detects, not quantified

ND Not detected

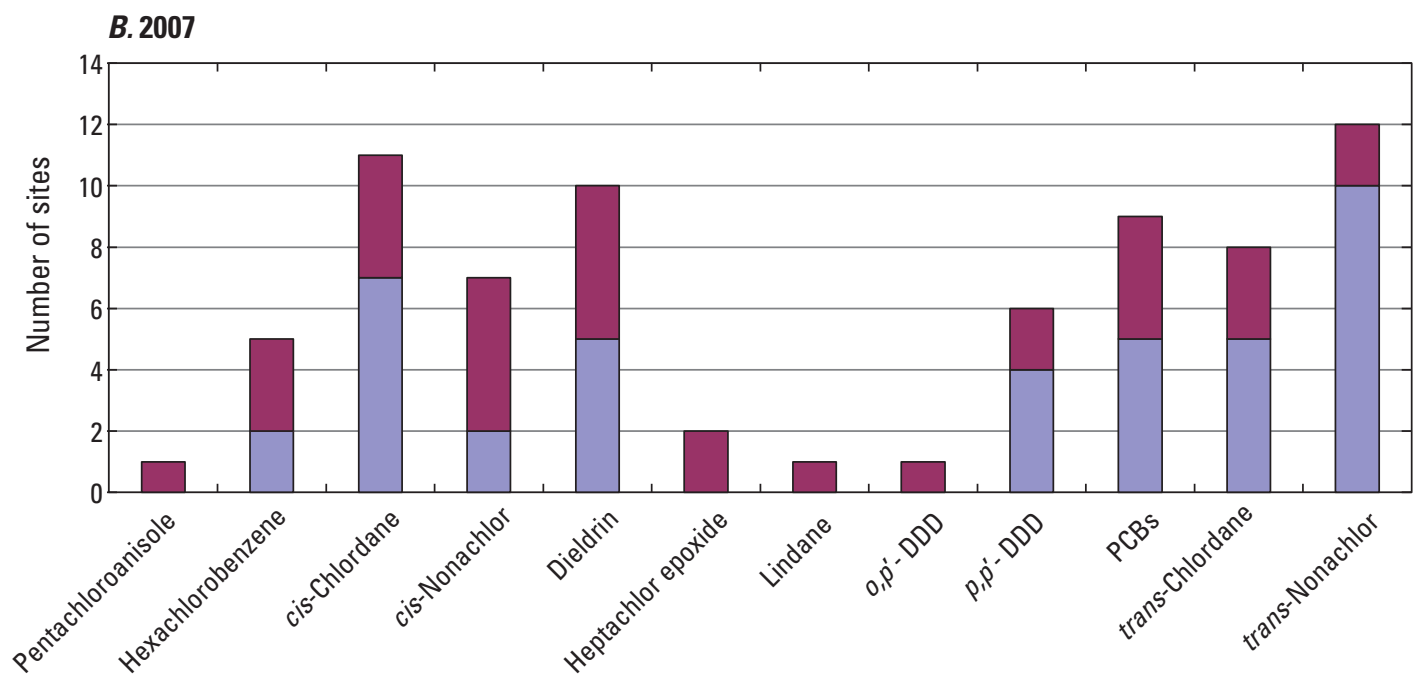

Figure 8. Number of sites at which chlorinated pesticides were detected in streambed-sediment samples. $A, 2005 . B, 2007$. 


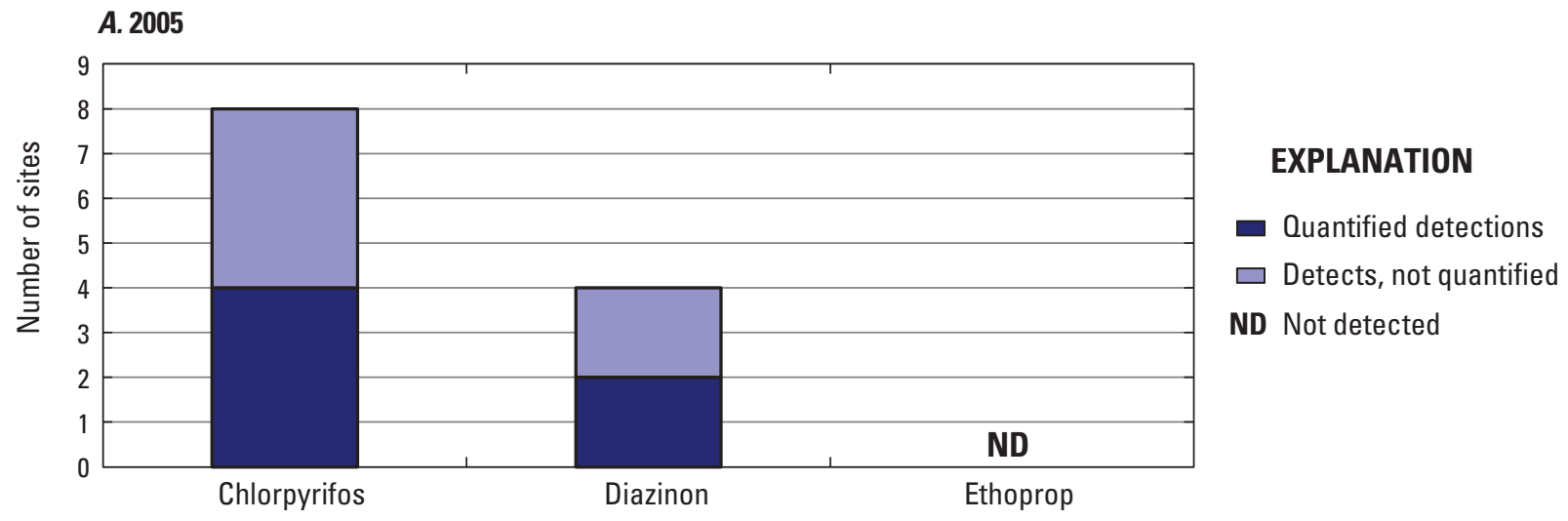

\section{B. 2007}

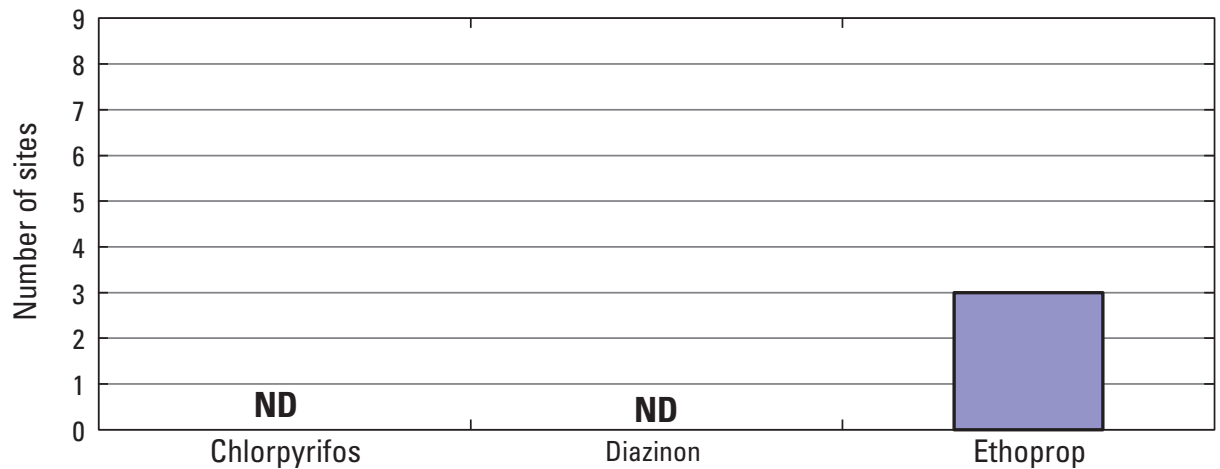

Figure 9. Number of sites at which organophosphate pesticides were detected in streambed sediment samples. $A$, 2005. B, 2007. 

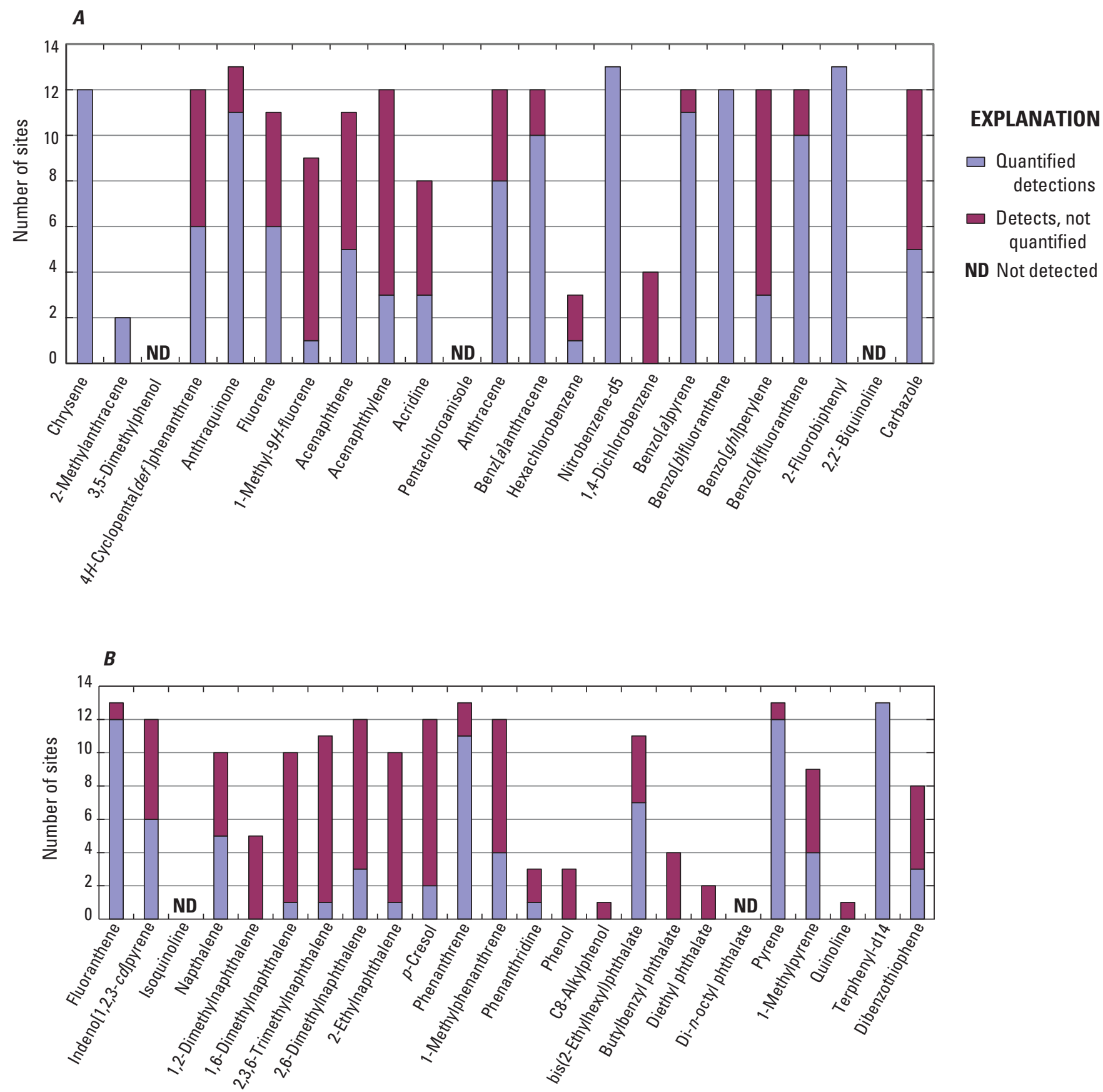

Figure 10. Number of sites at which selected semivolatile organic compounds (SVOCs) were detected in streambed sediments, 2005. 

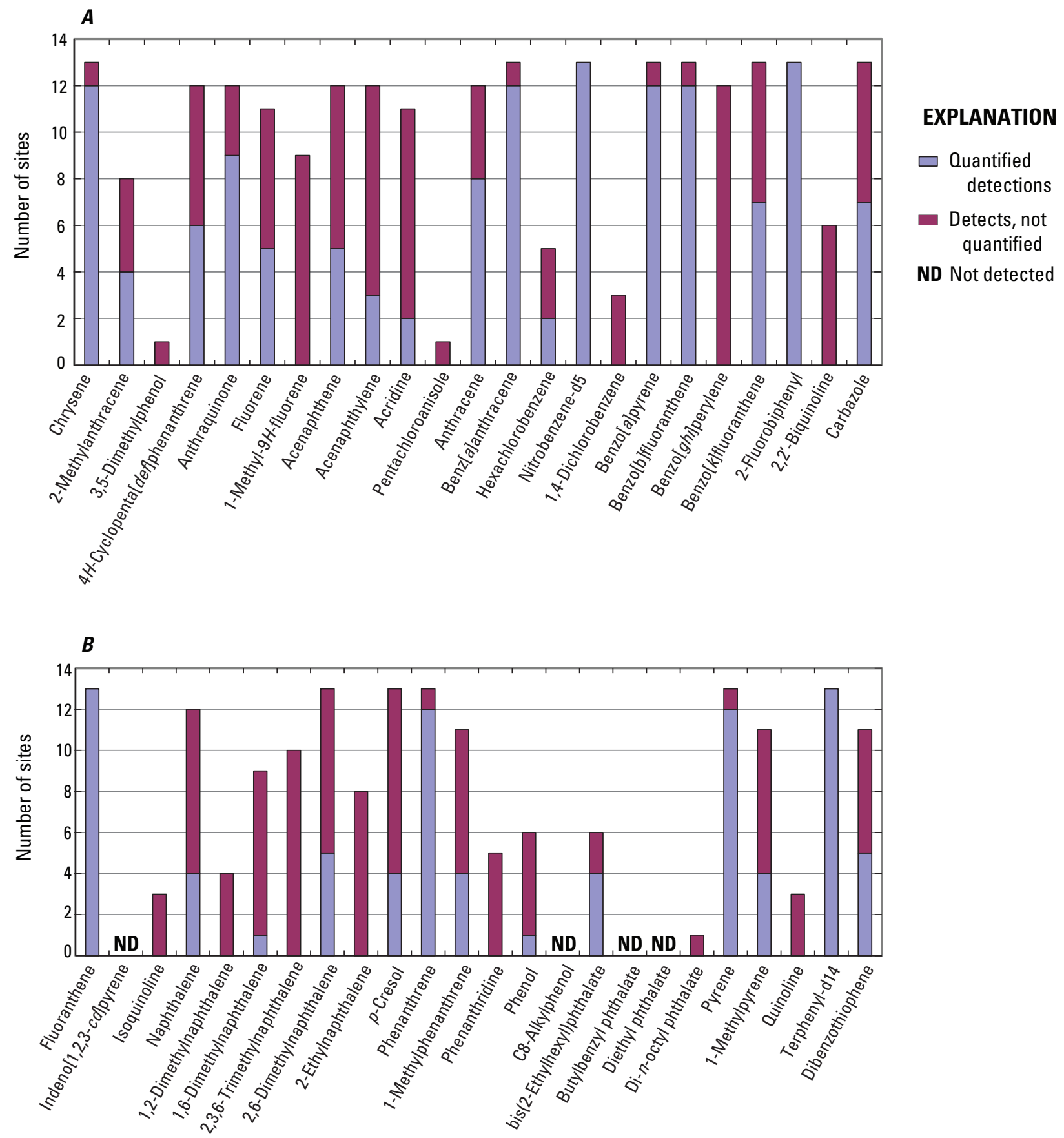

Figure 11. Number of sites at which selected semivolatile organic compounds (SVOCs) were detected in streambed sediments, 2007. 


\section{Temporal Patterns}

Intermittent collection of benthic-invertebrate data in the study area began in 1981 with a study by Crawford and others (1992) at or near three current study sites (Nora, Stout, and Waverly). That study collected data from those sites through 1987. From 1994 through 1996, 12 of the 13 sites in the current study were sampled, with the results reported by Voelker and Renn (2000). That study also included streambedsediment analyses. From 1999 through 2001, a third cooperative program between the USGS and DPW collected benthicinvertebrate and fish-community data (Voelker, 2004). From 2003 through 2008, benthic-invertebrate, fish-community, and streambed-sediment data were again collected by the USGS. In the following section, a historical perspective of the available data is presented.

\section{Ephemeroptera, Plecoptera, and Trichoptera (EPT) Index}

EPT scores were calculated at 3 sites from 1981 through 1987 (Crawford and others, 1992), 12 sites from 1994 through 1996 (Voelker and Renn, 2000), 12 sites from 1999 through 2001 (Voelker, 2004), and 13 sites since 2003 for this study. The results of the EPT scores are listed in table 4. EPT scores at most sites have generally increased, with the highest scores commonly in the years since 2003. In contrast, the scores at the Buck Creek site have indicated a downward trend in stream quality since sampling began there in 1999. The increases in these scores at most of the sites indicate that conditions supporting these pollution-intolerant taxa have improved over time. On the White River, the highest number of these taxa consistently were found at the Nora site, whereas the lowest numbers were found at the Harding site (fig. 12). For the tributaries, Buck Creek consistently had the highest number of these taxa, and Pogues Run had the lowest.

\section{Hilsenhoff Biotic Index (HBI) Scores}

HBI scores were calculated at 3 sites from 1981 through 1987 (Crawford and others, 1992), 12 sites from 1984 through 1996 (Voelker and Renn, 2000), 12 sites from 1999 through 2001 (Voelker, 2004), and 13 sites since 2003 for this study. The results of the HBI calculations are shown in table 5. HBI scores fluctuated fairly randomly over the course of the study, although many of the lowest scores - indicating the least amount of organic pollution-occurred in the mid-1990s for sites on the White River. HBI results indicate that the Morris and Harding sites likely had the highest levels of organic pollution whereas Nora had the least (fig. 13). For the tributaries, the three sites with the most CSOs-Fall Creek, Pleasant Run, and Pogues Run - had the highest amounts of organic pollution, whereas Buck and Williams Creeks had slightly lower amounts.

\section{Invertebrate Community Index (ICI) Scores}

ICI scores have been calculated from data collected since 1999 (Voelker, 2004). In general, scores have been increasing since 1999 (table 6), with the highest scores observed at 10 of the sites since October 2006. On the White River, ICI scores were generally highest at the Nora site, whereas the scores were typically lowest at the Morris and Harding sites, indicating the poorest invertebrate-community conditions (fig. 14). Of the tributary sites, results were similar for Buck and Williams Creeks, indicating the best invertebrate community conditions, while scores at Fall Creek were the lowest among the tributaries; however, the trend for scores at both the Buck Creek and Williams Creek sites shows a decrease over time.

\section{Changes in Pollution-Tolerant and Pollution- Intolerant Benthic-Invertebrate Populations}

Three sites on the White River were originally selected to observe changes in the benthic-invertebrate population with changes to the City's WWTFs. The Nora and Waverly sites have shown an increase in the percentage of pollution-tolerant invertebrates over pollution-intolerant species since 1981 (fig. 15). At the Nora site, there was also an overall downward trend in the number of pollution-intolerant benthic invertebrates with a corresponding increase in the pollution-tolerant numbers. From 1981 through 1989, the intolerant species predominated except in 1983 and 1985. From 2000 through 2008, the opposite was true; more tolerant invertebrates were present in samples, with the exception of 2006. This change may have been partially due to an upstream chemical release into the White River and resultant fish kill in late 1999 (Indiana Department of Environmental Management, 2000).

In 1983, Indianapolis upgraded its two WWTFs to tertiary treatment, including ozonation of the final effluent (Crawford and others, 1992). Soon after this, two sites downstream from the WWTFs showed signs of improved conditions in the benthic-invertebrate population (fig. 15). Ozonation was replaced with chlorination in 1994 (Paul Werderitch, DPW, oral commun., 2011). In 1996, pollution-tolerant invertebrates again predominated at the Stout site, and since then their numbers have remained comparable to the pollution-intolerant invertebrates at that site. The Waverly site, downstream from all CSO and wastewater outputs, showed an increase in pollution-tolerant invertebrates in data from all years since 1999, with the exception of 2007. 


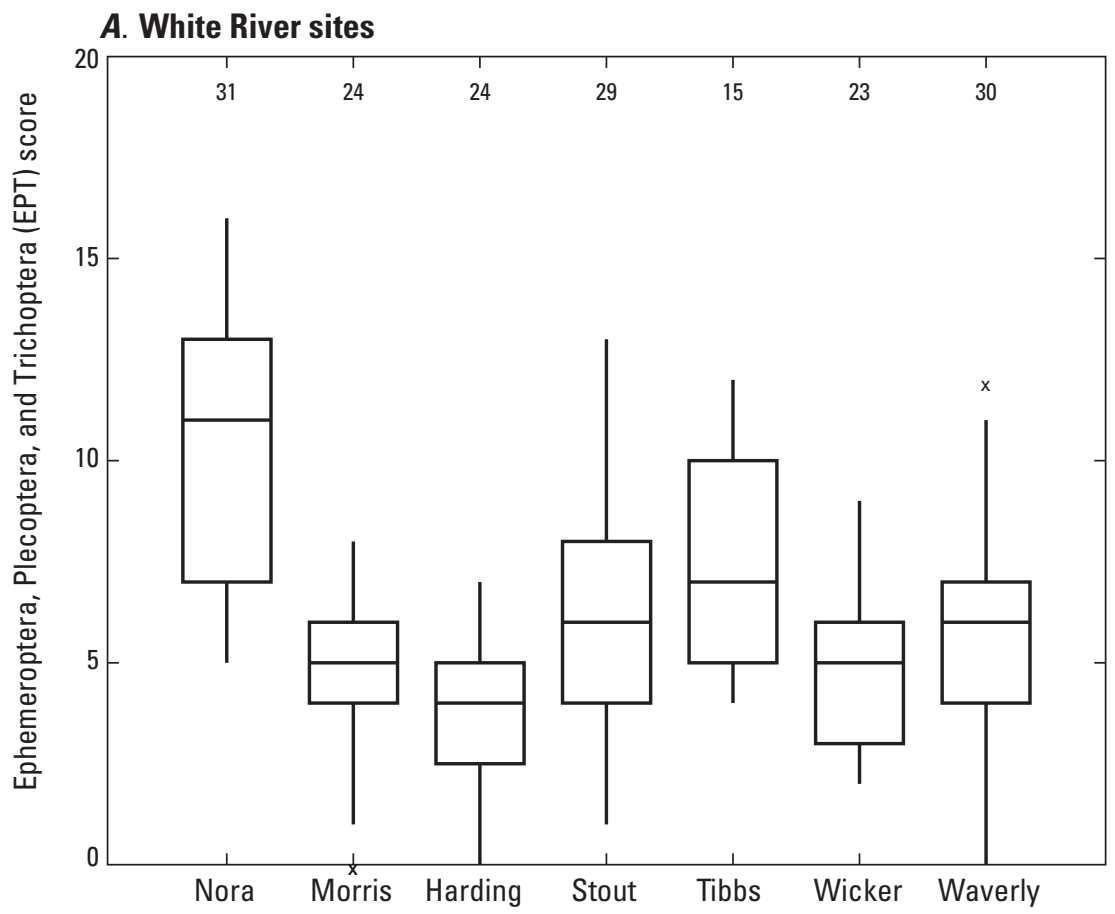

\section{EXPLANATION}

$30 \quad$ Number of samples

- Upper detached

$x \quad$ Upper outside

Upper adjacent

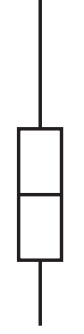

75th percentile

Median

25th percentile

Lower adjacent

$x \quad$ Lower outside

- Lower detached

B. Tributary sites

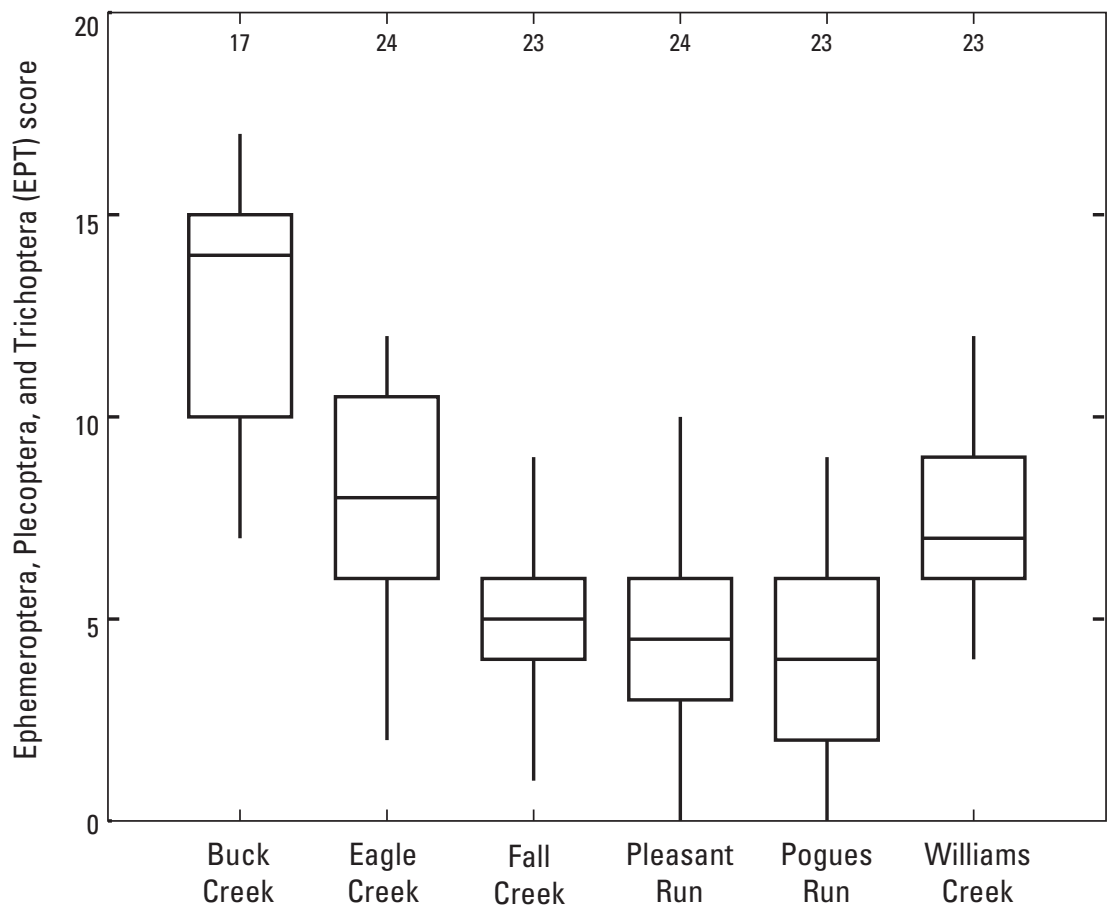

Figure 12. Ephemeroptera, Plecoptera, and Trichoptera (EPT) Index scores, 1981-2008. 

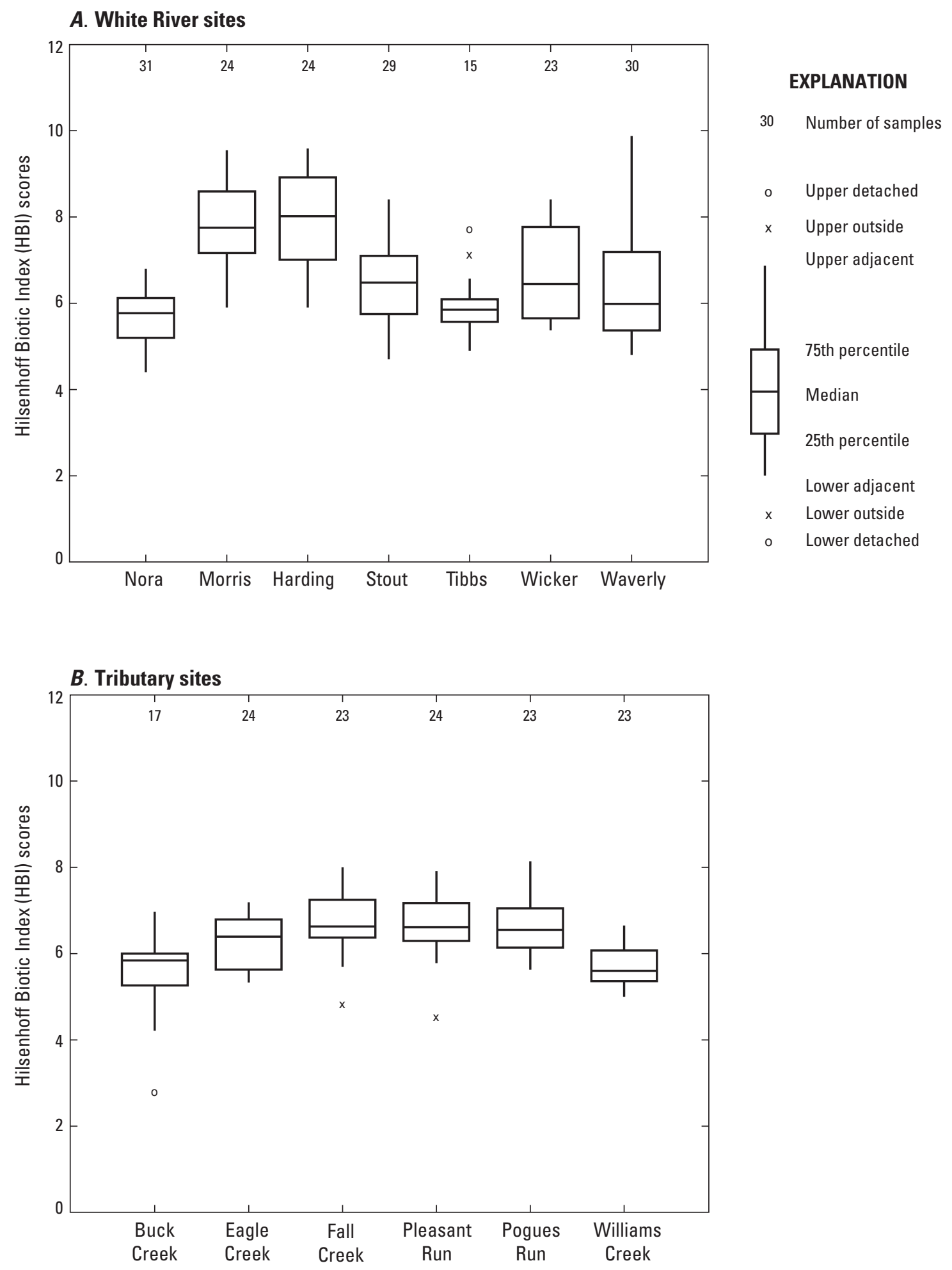

Figure 13. Hilsenhoff Biotic Index (HBI) scores, 1981-2008. 


\section{A. White River sites}

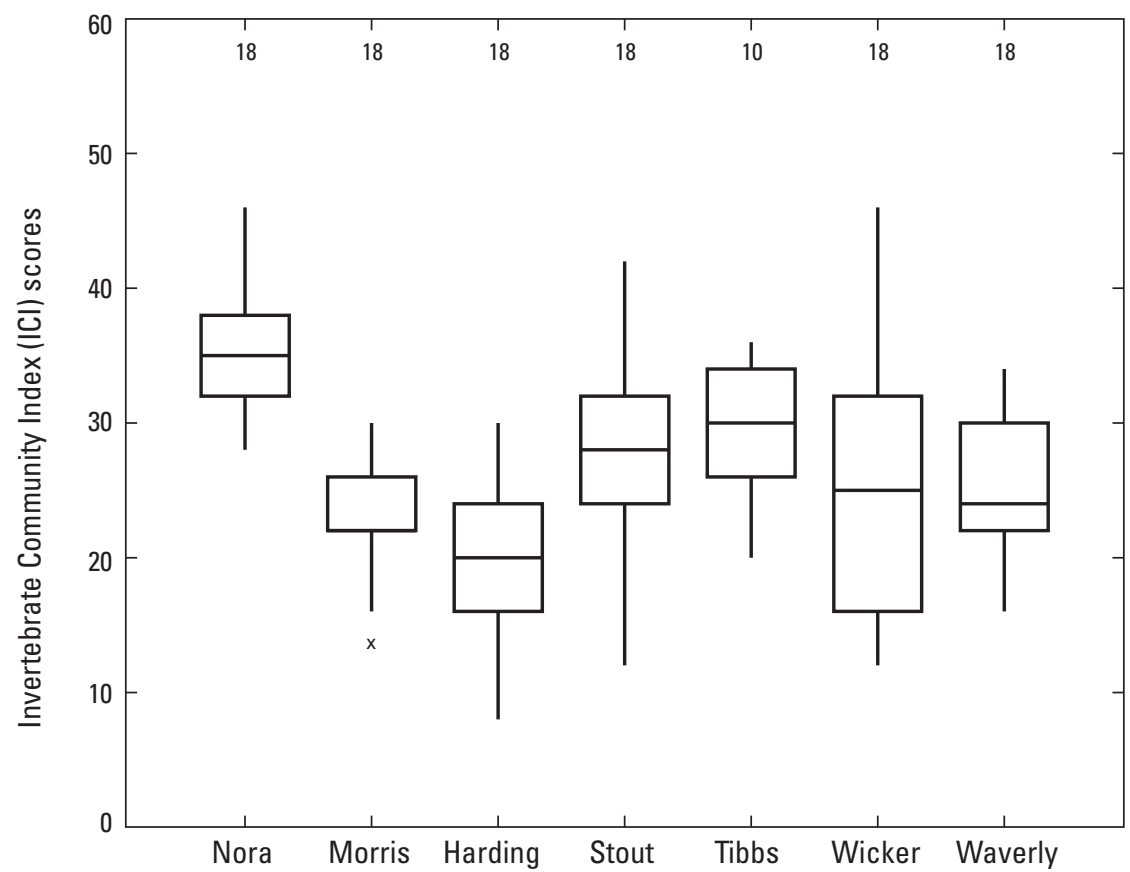

EXPLANATION

18 Number of samples

- Upper detached

x Upper outside

Upper adjacent

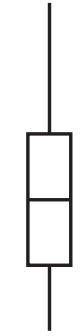

75th percentile

Median

25th percentile Lower adjacent

$x \quad$ Lower outside

- Lower detached

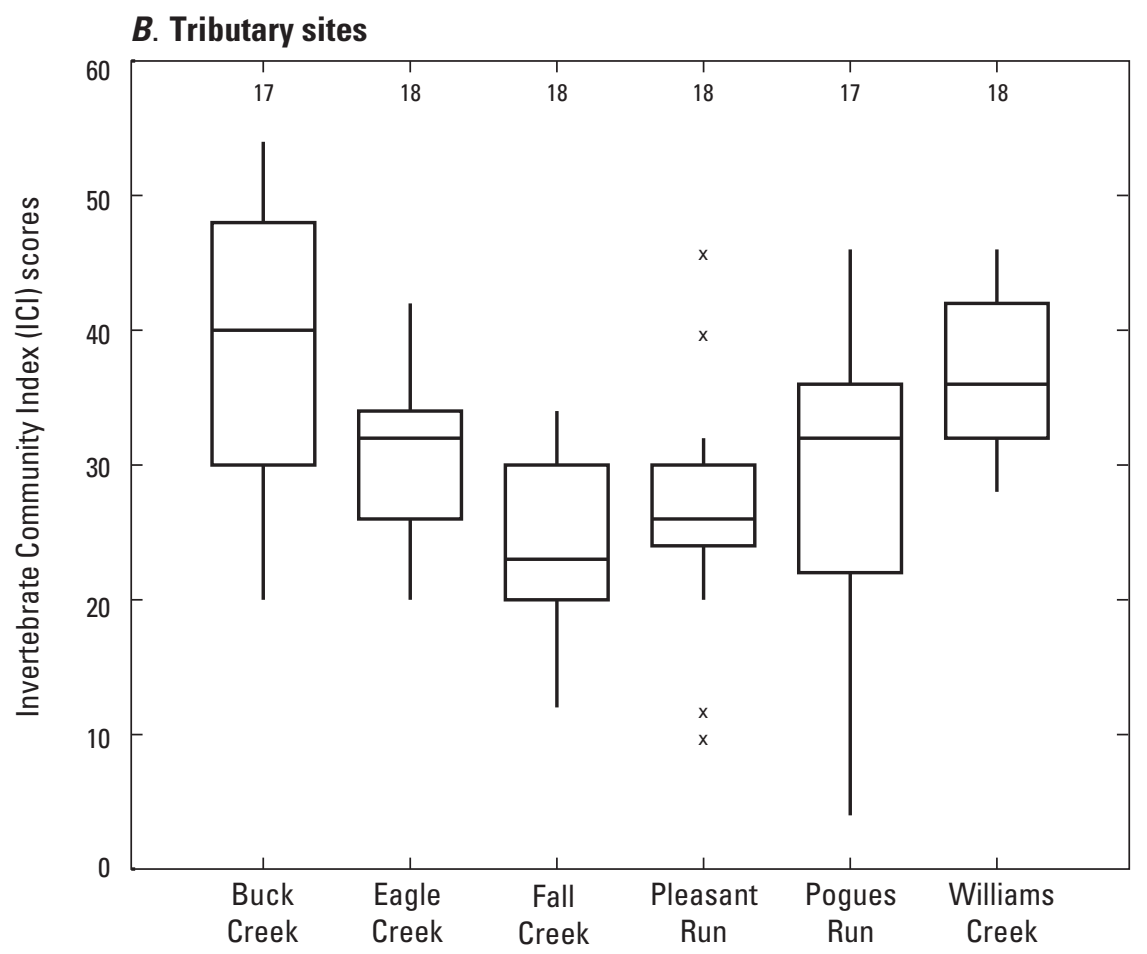

Figure 14. Invertebrate Community Index (ICI) scores, 1999-2008. 
A. White River at Westfield Boulevard (1981-7) and at Nora (1994-2008)

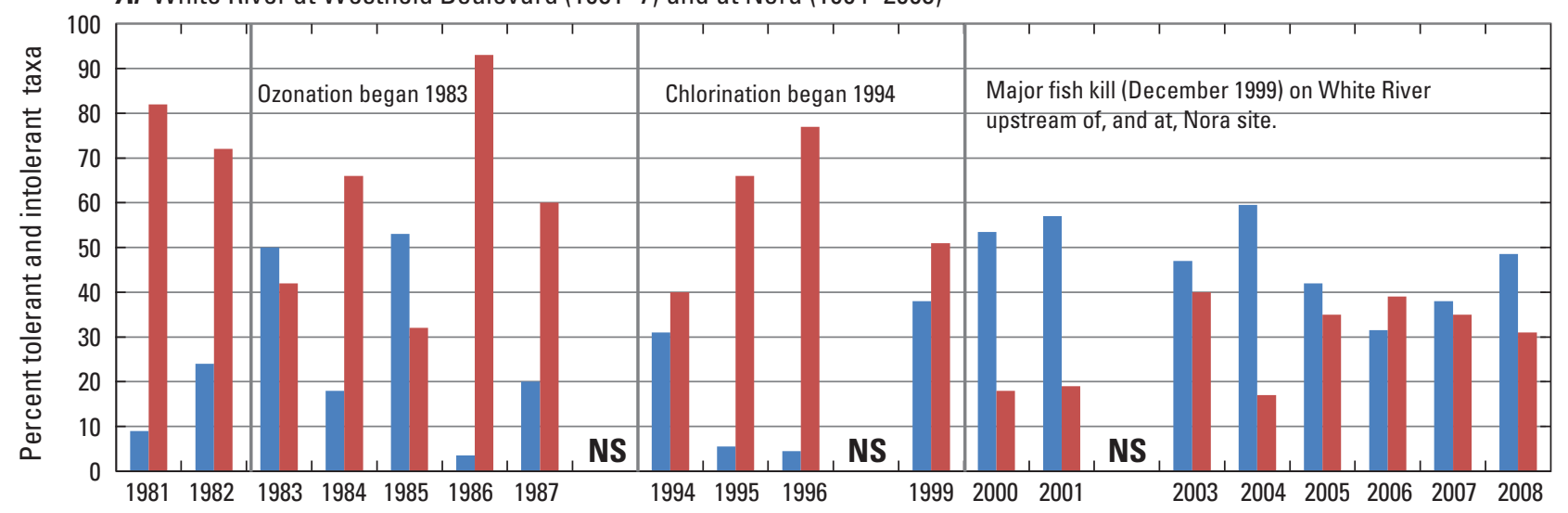

B. White River below Stout Generating Station

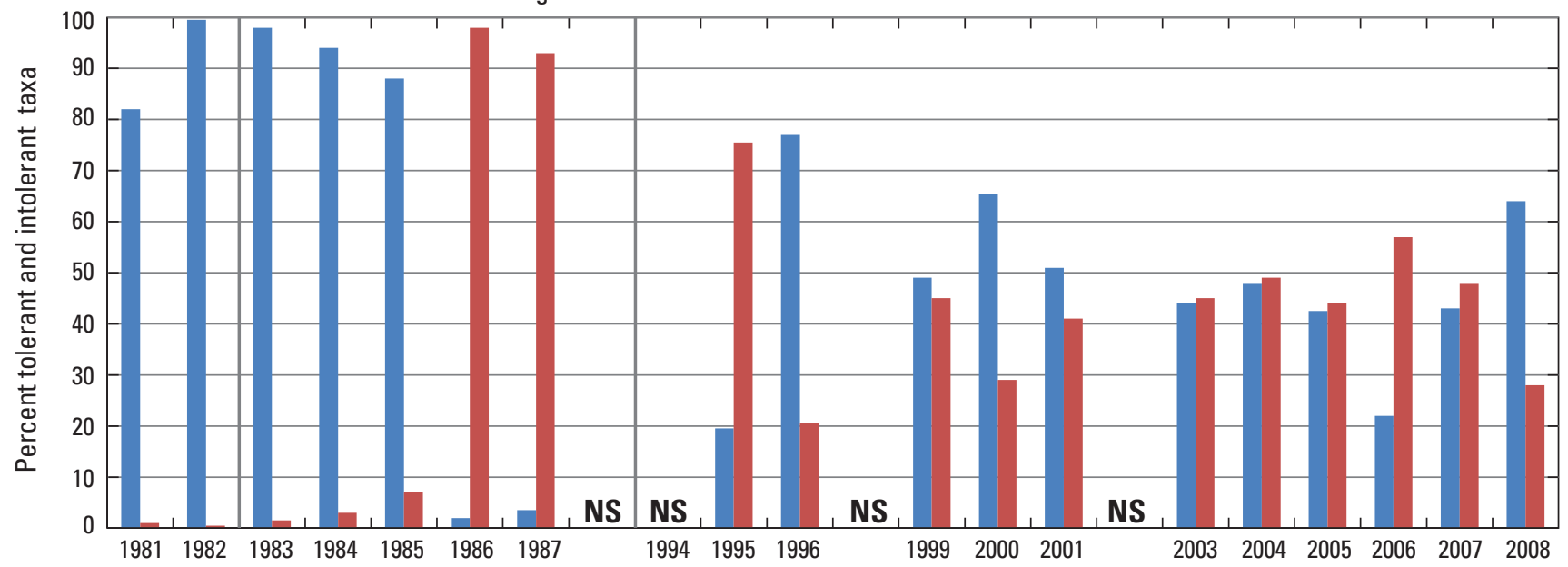

C. White River at Waverly

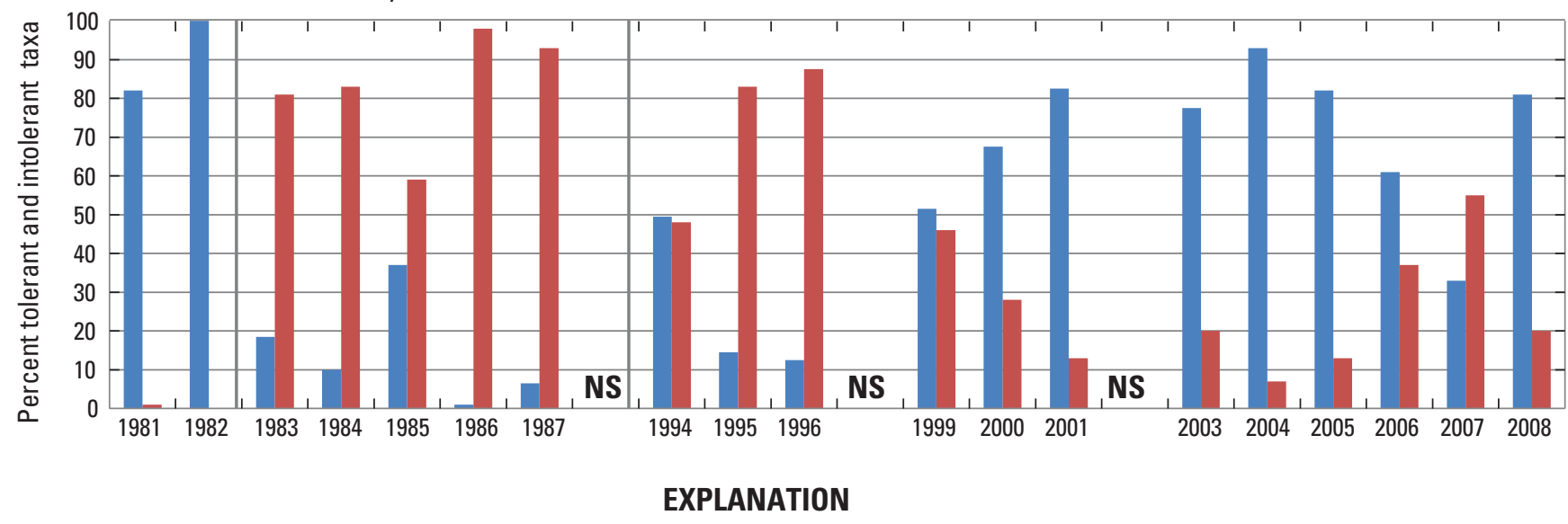

- Tolerant Intolerant NS Not sampled

Figure 15. Historical percentage of pollution-tolerant and pollution-intolerant benthic invertebrates at selected sites on the White River, 1981-2008. 
Data since 1994 are available for most other sites on the White River, except for the Tibbs site, where these values have been calculated only since 2004. At those sites, the graphs show downward trends in the percentage of pollution-tolerant benthic invertebrates present. Both the Morris and Harding sites are predominated by pollution-tolerant invertebrates, with virtually no pollution-intolerant invertebrates present (fig. 16). The Tibbs site had a predominance of pollution-intolerant benthic invertebrates in 2005 and 2006, unlike other White River sites during the study period.

Three tributary sites-Buck Creek, Pogues Run and Williams Creek-had increasing numbers of pollution-tolerant benthic invertebrates (fig. 17). Of these three sites, the Pogues Run site has been predominated by pollution-tolerant invertebrates, and their numbers have been slowly increasing since 1984. Similarly, the Pleasant Run site has been predominated by pollution-tolerant benthic invertebrates; but unlike the Pogues Run site, their numbers have been trending downward over the study period. Both the Pleasant Run and Pogues Run sites have had minor, yet steady, increases in pollution-intolerant benthic invertebrates since the mid-1990s.

\section{Index of Biotic Integrity (IBI) scores}

IBI scores were calculated for samples collected in 1999 and later (Voelker, 2004) (table 12). IBI scores calculated from the fish-community data collected in 1999-2001, 2006, and 2008 are shown in figure 18. Since 1999, six of the seven White River sites and the three of the six tributary sites had the lowest scores during 2006. Low-flow conditions (table 2) during 2006 may have contributed to the lower scores that year.

\section{Streambed-Sediment Chemistry}

Streambed-sediment chemistry data collected by this study were compared with data from Voelker and Renn (2000). The maximum concentrations of most metals and SVOCs were higher in samples collected during 2005 and 2007 than in samples collected during 1994-96. The highest concentrations of these constituents among all sites were measured in samples from the White River sites. Data relative to pesticide analyses indicated that concentrations were similar between the two studies, with no evident variation. Because of the mobility of the fine-grained sediments from which these concentrations were determined, their transient nature in the stream, and the intermittent sampling schedule, additional comparison with data from the previous study is not made here.

\section{Combining Metrics to Evaluate Biological Response to CSOs}

Combining biological metrics provides a more nuanced understanding of the biological response to CSOs than considering the metrics individually. If each of the median metric scores by site is ranked, with 1 representing the best response, this ranking technique helps assess the relative biological condition at each site. Use of this approach underscores the individual findings that the biological communities at the non-CSO-affected sites on the tributaries-Buck Creek and Williams Creek - and the Nora site on the White River had the most pollution-intolerant taxa (table 13). Biological communities were most affected at the Harding and Waverly sites on the White River and at the Pogues Run, Pleasant Run, and Fall Creek sites on the tributaries. The three most affected tributary sites also had the greatest number of CSOs in their watershed.

The invertebrate community seemed to show a more uniform response to CSO influences than the fish community, especially at the tributary sites. The two non-CSO-affected tributaries had the lowest scores, and the three streams with the most CSOs had the highest scores. These combined findings were supported by the number of taxa and the EPT, HBI, and ICI indexes (table 13). Although, among the White River sites, Nora consistently had the lowest score (representative of a non-CSO-affected site), the other metrics were less effective at consistently identifying affected sites. For example, both Stout and Tibbs are downstream from most CSOs and one WWTF but have the second and third lowest scores, suggesting better biological conditions there. This could be the result of aeration from the low-head dam just upstream from the Stout site (positive effects) or possibly an indicator of the continued effects of the 1999 fish kill in the upper reaches of the study area.

Although the relative abundance of biota or number of taxa are valuable assessment tools, these metrics do not necessarily reflect the stress on the biological communities from CSOs. The greatest abundance of benthic invertebrates was found at sites directly below or downstream from one WWTF (Tibbs and Stout) or with the most CSOs discharging into the tributaries (Fall Creek). The WWTF and CSO outflows provide the nutrients to support the higher invertebrate abundance, although the invertebrate populations may not reflect that the best biological conditions are present at those sites. By using multiple indexes, a better assessment and more complete understanding of the biological conditions in the stream and possible stressors is achieved. 

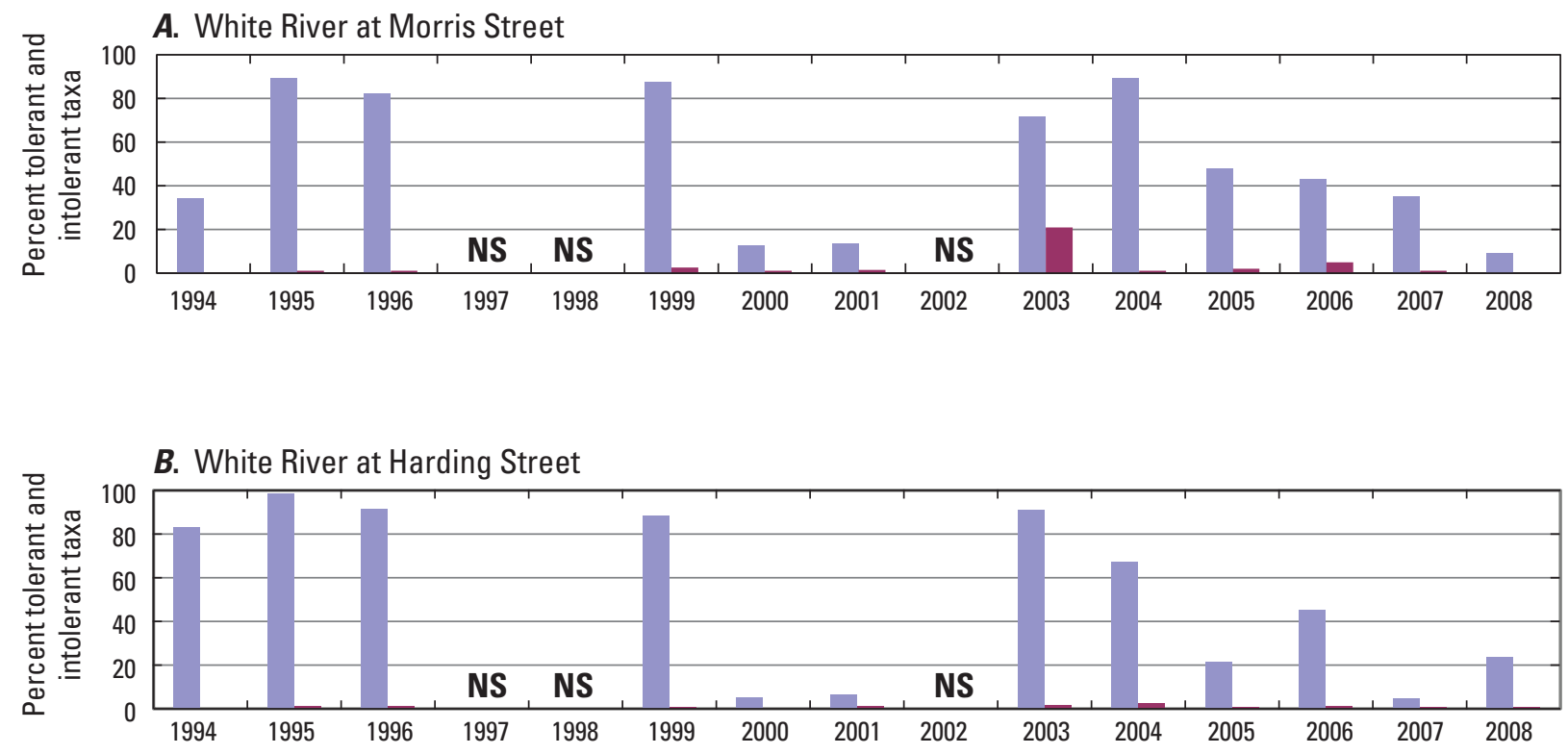

C. White River at Tibbs-Banta

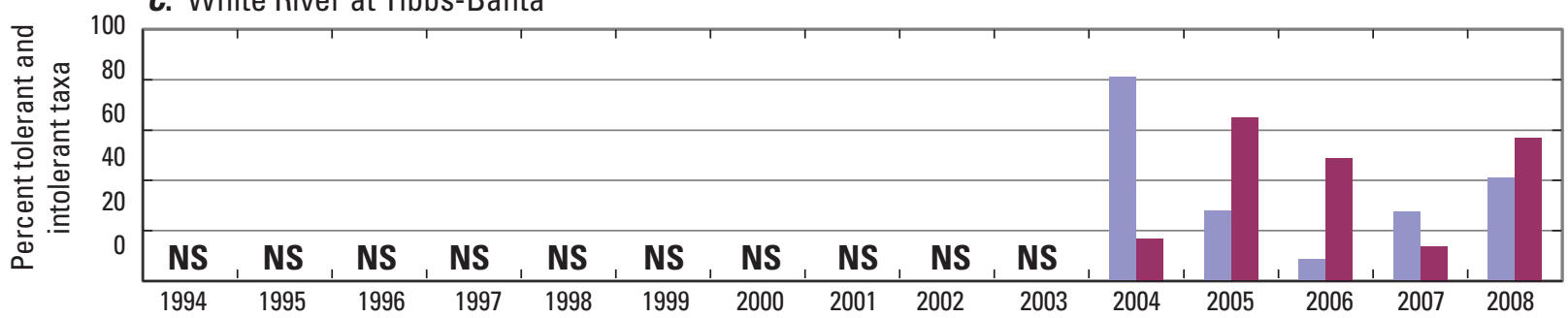

D. White River at Wicker Road

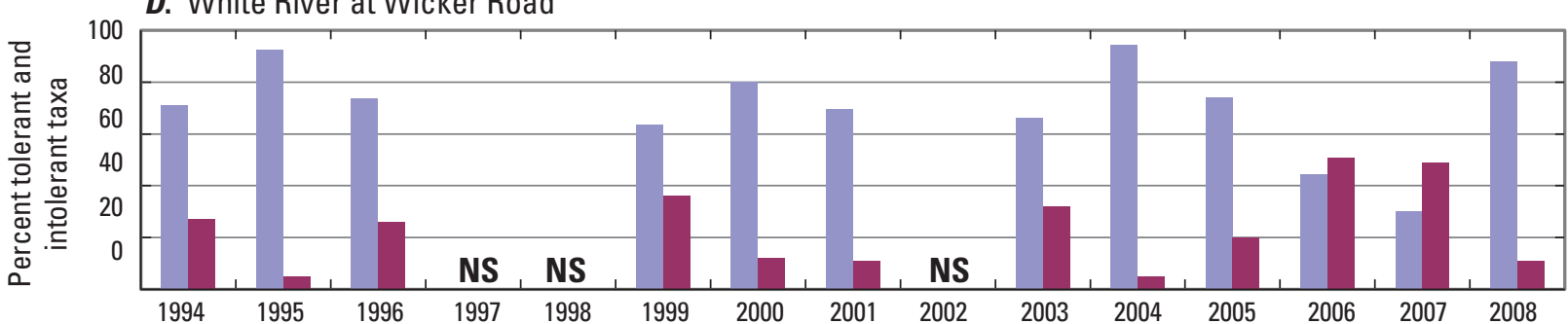

\section{EXPLANATION}
- Tolerant
- Intolerant
NS Not sampled

Figure 16. Historical percentage of pollution-tolerant and pollution-intolerant benthic invertebrates at White River sites, 1994-2008. 


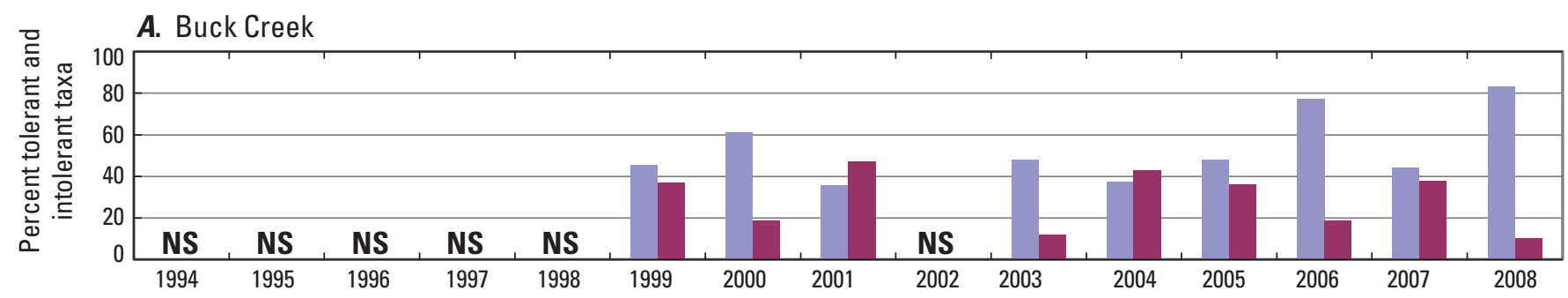

B. Eagle Creek

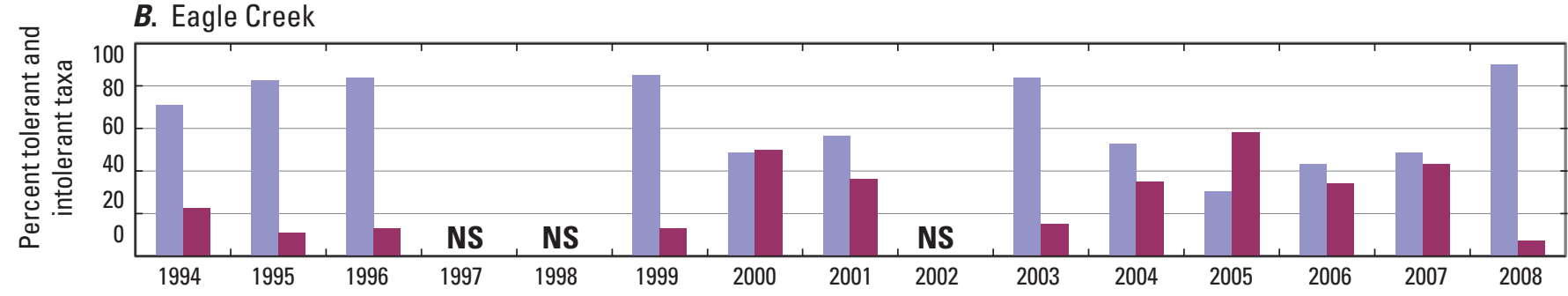

C. Fall Creek

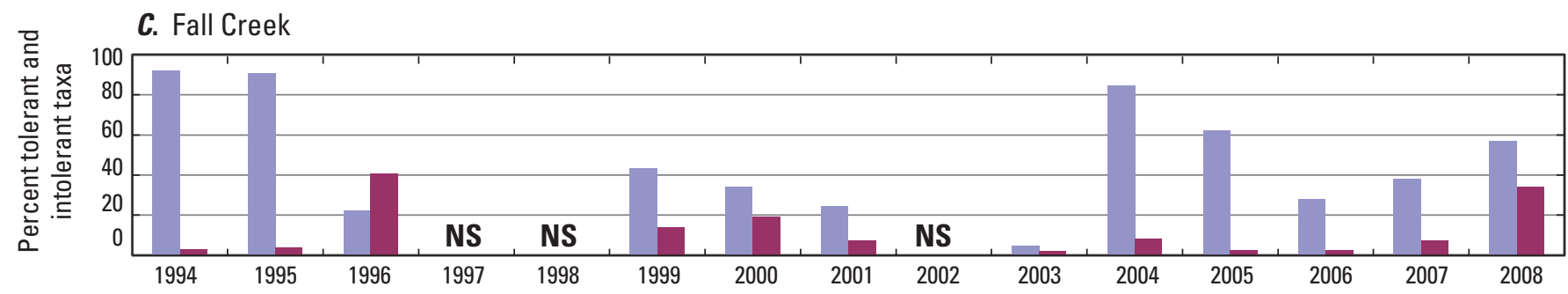

D. Pleasant Run

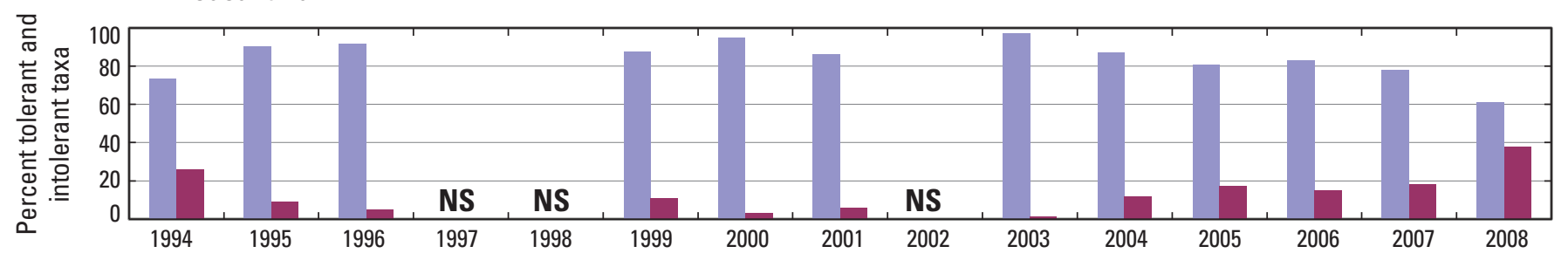

E. Pogues Run
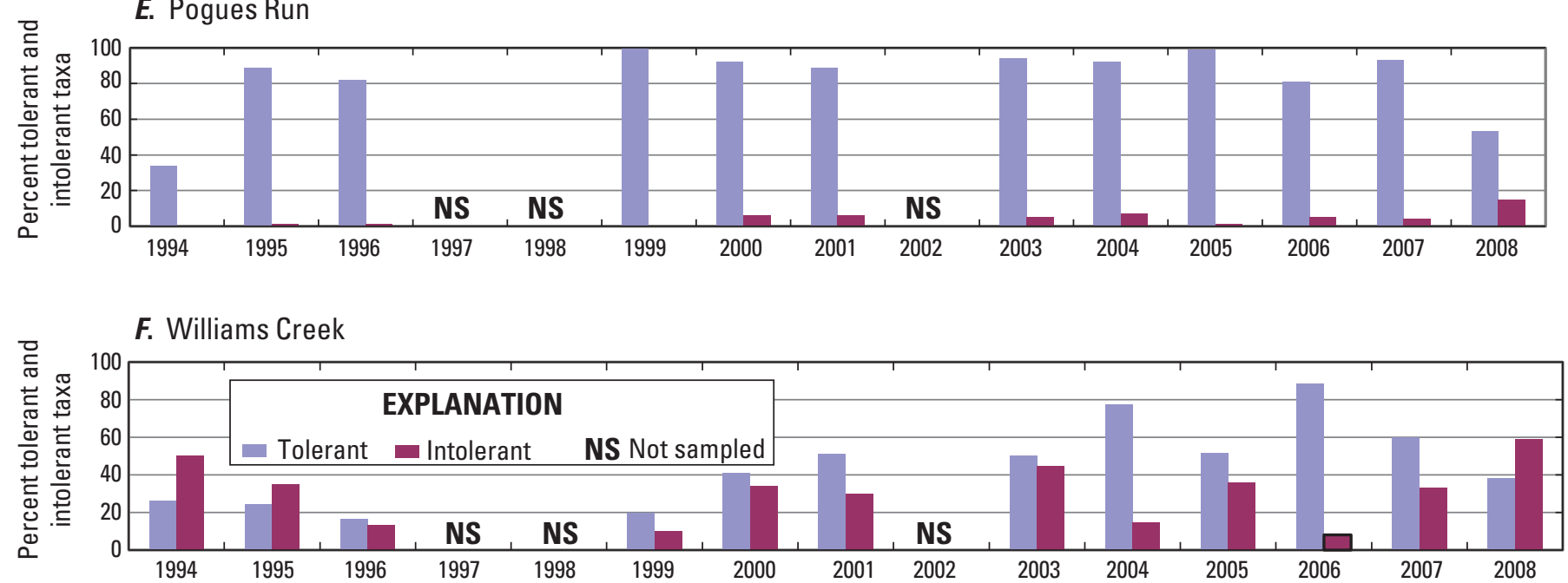

Figure 17. Historical percentage of pollution-tolerant and pollution-intolerant benthic invertebrates at tributary sites, 1994-2008. 
Table 12. Index of Biotic Integrity (IBI) scores at all sites in the Indianapolis metropolitan area, 1999-2008.

$[--$, no sample collected]

\begin{tabular}{|c|c|c|c|c|c|c|c|c|c|c|c|c|c|}
\hline Sample date & Nora & Morris & Harding & Stout & Tibbs & Wicker & Waverly & $\begin{array}{l}\text { Buck } \\
\text { Creek }\end{array}$ & $\begin{array}{l}\text { Eagle } \\
\text { Creek }\end{array}$ & $\begin{array}{c}\text { Fall } \\
\text { Creek }\end{array}$ & $\begin{array}{c}\text { Pleasant } \\
\text { Run }\end{array}$ & $\begin{array}{c}\text { Pogues } \\
\text { Run }\end{array}$ & $\begin{array}{c}\text { Williams } \\
\text { Creek }\end{array}$ \\
\hline \multicolumn{14}{|c|}{ Data from Voelker, 2004} \\
\hline 1999 & 44 & 40 & 38 & 42 & -- & 38 & 38 & -- & 48 & 54 & 36 & 30 & 44 \\
\hline 2000 & 34 & 46 & 42 & 50 & -- & 46 & 40 & 52 & 48 & 52 & 32 & 34 & 50 \\
\hline 2001 & 44 & 46 & 42 & 44 & -- & 40 & 36 & 52 & 48 & 52 & 30 & 28 & 48 \\
\hline \multicolumn{14}{|c|}{ Data from this study } \\
\hline 2006 & 38 & 32 & 20 & 42 & 40 & 44 & 30 & 52 & 40 & 52 & 40 & 26 & 44 \\
\hline 2008 & 46 & 52 & 36 & 46 & 42 & 46 & 34 & 50 & 44 & 50 & 44 & 26 & 52 \\
\hline \multicolumn{14}{|c|}{ Median values } \\
\hline 2006-2008 & 42 & 42 & 28 & 44 & 41 & 45 & 32 & 51 & 42 & 51 & 42 & 26 & 48 \\
\hline 1999-2008 & 44 & 46 & 38 & 44 & 41 & 44 & 36 & 52 & 48 & 52 & 36 & 28 & 48 \\
\hline
\end{tabular}




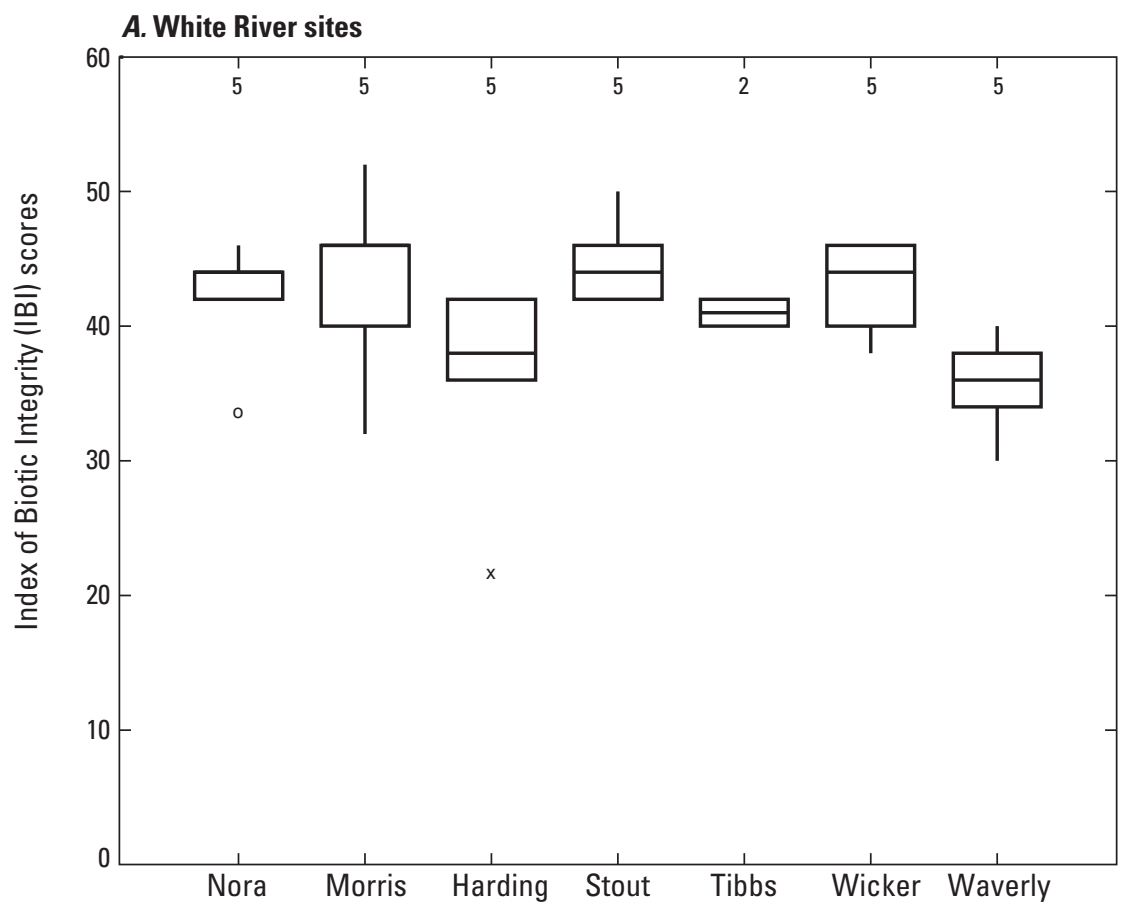

\section{EXPLANATION}

$5 \quad$ Number of samples

- Upper detached

x Upper outside Upper adjacent

75th percentile

Median

25th percentile

Lower adjacent

$x \quad$ Lower outside

- Lower detached

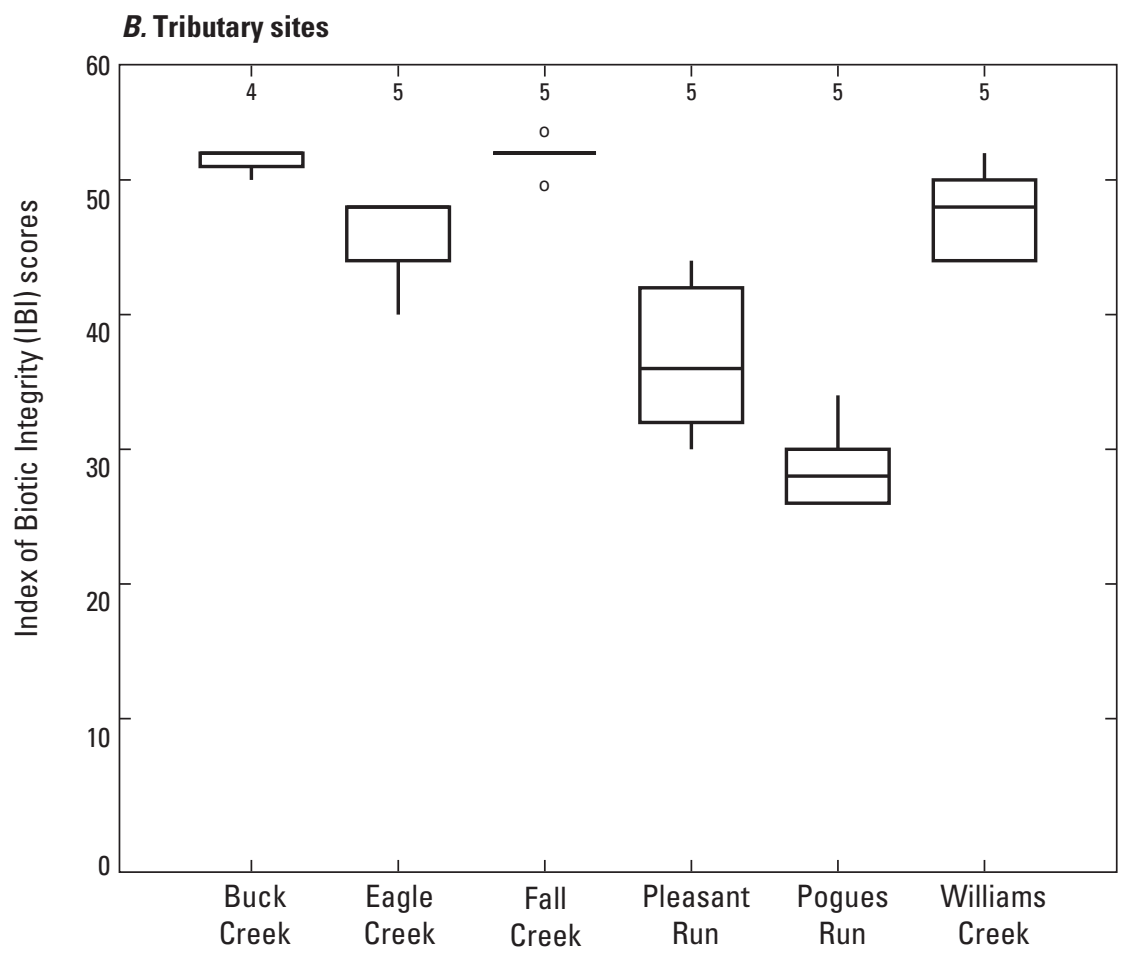

Figure 18. Historical Index of Biotic Integrity (IBI) scores, 1999-2008. A, Sites on the White River. $B$, Tributary sites. 
Table 13. Ranking of sites by benthic invertebrate and fish metrics and index scores for sites on the White River and tributary sites in the Indianapolis metropolitan area, $1981-2008$.

[CSO, combined-sewer overflow; EPT, Ephemeroptera, Plecoptera, and Trichoptera; HBI, Hilsenhoff Biotic Index; ICI, Invertebrate Community Index; IBI, Index of Biotic Integrity]

\begin{tabular}{|c|c|c|c|c|c|c|c|c|c|c|c|c|c|}
\hline \multirow[b]{2}{*}{ Site } & \multirow[b]{2}{*}{$\begin{array}{l}\text { Site type } \\
\text { (number } \\
\text { of } \mathrm{CSOs} \text { ) }\end{array}$} & \multicolumn{5}{|c|}{ Benthic invertebrates } & \multicolumn{4}{|c|}{ Fish } & \multicolumn{3}{|c|}{ Summary rankings } \\
\hline & & $\begin{array}{c}\text { Number } \\
\text { of taxa }\end{array}$ & $\begin{array}{c}\text { Relative } \\
\text { abun- } \\
\text { dance }\end{array}$ & $\begin{array}{l}\text { EPT } \\
\text { Index } \\
\text { score }\end{array}$ & $\begin{array}{c}\text { HBI } \\
\text { scores }\end{array}$ & $\begin{array}{c}\text { ICI } \\
\text { scores }\end{array}$ & $\begin{array}{c}\text { Relative } \\
\text { abun- } \\
\text { dance }\end{array}$ & $\begin{array}{c}\text { IBI } \\
\text { scores }\end{array}$ & $\begin{array}{c}\text { Number } \\
\text { of taxa }\end{array}$ & Total & $\begin{array}{c}\text { Benthic } \\
\text { inverte- } \\
\text { brates } \\
\text { only }\end{array}$ & Fish only & Both \\
\hline \multicolumn{14}{|c|}{ White River sites } \\
\hline Nora & Non-CSO & 1 & 3 & 1 & 1 & 1 & 6 & 3 & 7 & 23 & 1.4 & 5.3 & 2.9 \\
\hline Morris & & 2 & 7 & 5.5 & 6 & 6 & 2 & 1 & 2 & 31.5 & 5.3 & 1.7 & 3.9 \\
\hline Harding & & 3 & 5 & 7 & 7 & 7 & 5 & 6 & 4.5 & 44.5 & 5.8 & 5.2 & 5.6 \\
\hline Stout & & 4 & 2 & 2.5 & 5 & 3 & 3 & 3 & 1 & 23.5 & 3.3 & 2.3 & 2.9 \\
\hline Tibbs & & 7 & 1 & 2.5 & 2 & 2 & 1 & 5 & 3 & 23.5 & 2.9 & 3.0 & 2.9 \\
\hline Wicker & & 5.5 & 6 & 5.5 & 4 & 4 & 4 & 3 & 4.5 & 36.5 & 5 & 3.8 & 4.6 \\
\hline Waverly & & 5.5 & 4 & 4 & 3 & 5 & 7 & 7 & 6 & 41.5 & 4.3 & 6.7 & 5.2 \\
\hline \multicolumn{14}{|c|}{ Tributary sites } \\
\hline Buck Creek & Non-CSO & 1 & 3 & 1 & 2 & 1 & 3 & 1.5 & 1 & 13.5 & 1.6 & 1.8 & 1.7 \\
\hline Eagle Creek & 5 & 2 & 5 & 2 & 3 & 4 & 4 & 3.5 & 3 & 26.5 & 3.2 & 3.5 & 3.3 \\
\hline Fall Creek & 49 & 4 & 1 & 4.5 & 6 & 6 & 5 & 1.5 & 2 & 30 & 4.3 & 2.8 & 3.8 \\
\hline Pleasant Run & 27 & 6 & 4 & 4.5 & 5 & 5 & 1 & 5 & 5 & 35.5 & 4.9 & 3.7 & 4.4 \\
\hline Pogues Run & 24 & 5 & 6 & 6 & 4 & 3 & 6 & 6 & 6 & 42 & 4.8 & 6.0 & 5.3 \\
\hline $\begin{array}{c}\text { Williams } \\
\text { Creek }\end{array}$ & Non-CSO & 3 & 2 & 3 & 1 & 2 & 2 & 3.5 & 4 & 20.5 & 2.2 & 3.2 & 2.6 \\
\hline
\end{tabular}




\section{Summary}

The U.S. Geological Survey, in cooperation with the Indianapolis Department of Public Works (DPW), assessed biological communities and streambed-sediment chemistry in the White River and selected tributaries in the Indianapolis metropolitan area during 2003 through 2008. Thirteen sites (seven on the White River and six on tributaries) were sampled biannually for benthic invertebrates and in alternating years for fish communities or streambed-sediment chemistry. This study continued a long-term cooperative program between the two agencies to collect biological and streambed-sediment data and complement the DPW surface-water monitoring program. The information gathered is being used in the City's programs to reduce combined-sewer overflows (CSOs) and other point and nonpoint sources of pollution in the Indianapolis area.

During this study, 233 benthic-invertebrate taxa were identified, with 17 to 60 taxa being identified in samples from individual sites. Dipterans, a pollution-tolerant group of taxa, tended to be the predominant taxa in most samples. Three benthic-invertebrate indexes were calculated from the data collected at each site: the Ephemeroptera, Plecoptera, and Trichoptera (EPT) Index, the Hilsenhoff Biotic Index (HBI), and the Invertebrate Community Index (ICI).

EPT Index scores ranged from 2 at the Harding and Wicker sites to 16 at Nora on the White River. On the tributaries, the scores ranged from 2 at the Eagle Creek, Fall Creek, and Pogues Run sites to 17 at Buck Creek. EPT Index scores indicate that pollution-intolerant taxa are more prevalent upstream from and away from the combined-sewer areas. HBI scores ranged from 4.67 (good) at Nora to 9.55 (very poor) at the Morris sites on the White River. On the tributaries, HBI scores ranged from 4.21 (very good) at Buck Creek to 8.14 (poor) at Pogues Run. Lower HBI scores indicate less organic pollution, and again, sites upstream from and away from CSOs had lower scores. ICI scores on the White River ranged from 12 at Harding and Wicker to 46 at Nora, indicating better conditions upstream from the CSO area. On the tributaries, ICI scores ranged from 12 at Fall Creek to 52 at the Buck Creek site. The highest scores were generally at sites unaffected by CSOs.

Fish-community data collected during this study identified 65 taxa. Fifty-one fish species were identified on the White River, and 53 fish species were identified on tributaries. The number of fish species identified by site ranged from 16 at Waverly to 27 at Stout on the White River and from 8 at Pogues Run to 34 at Buck Creek on the tributaries. The Centrarchidae (sunfishes) composed 20 percent of the specimens caught on the White River, whereas the Cyprinidae (carps and minnows) composed about 30 percent of the specimens on the tributaries. Index of Biotic Integrity (IBI) scores for the White River ranged from 20 at Harding to 52 at Morris. Tributary IBI scores ranged from 26 at Pogues Run to 52 at Buck Creek, Fall Creek, and Williams Creek.
Streambed sediments were collected twice during the study period to assess chemical constituents that may affect the biological communities at the study sites. More chlorinated pesticides were detected in 2007 than in 2005, with transnonachlor, cis-chlordane, dieldrin, trans-chlordane, and PCBs being most frequently detected. Only three organophosphate insecticides were detected. More than 30 semivolatile organic compounds (SVOCs) were detected at more than half the sites sampled. The Harding site had the highest concentrations and the Buck Creek site had the lowest concentrations among all sites sampled.

For sites on the White River, available historical data for each of the three indexes (EPT, HBI, and ICI) all show that the benthic-invertebrate conditions are least impaired at the Nora site. The Nora site is the most upstream study site, near where the White River enters Indianapolis and upstream from the CSO area. The highest number of pollution-tolerant taxa within the benthic-invertebrate communities are at the Morris and Harding sites, which are in the most urban reach of the river. There is some improvement in the benthic-invertebrate metrics at the Stout and Tibbs sites, and to a lesser extent at the Wicker and Waverly sites, further downstream from the CSOs and wastewater treatment facilities.

Results from this study continue to describe the Buck Creek and Williams Creek sites - which have no CSOs entering them - as having more pollution-intolerant benthicinvertebrate communities than the other tributary sites. Only the Eagle Creek site had scores higher than the Williams Creek site with regard to EPT index scores. Fall Creek, Pleasant Run, and Pogues Run consistently scored poorest of the tributary sites, with the Pogues Run site having the greatest range in ICI scores.

Three sites on the White River have had a longer history of benthic-invertebrate data from which numbers of pollutiontolerant and pollution-intolerant invertebrates have been calculated. Dominance by pollution-tolerant invertebrates was reversed at the two downstream sites (Stout and Waverly) after the wastewater treatment facilities upgraded to tertiary treatment with ozonation. That trend lasted until ozonation was replaced by chlorination of effluents in the mid-1990s. The only other change in benthic-invertebrate conditions occurred in late 1999, when a chemical spill resulted in a major fish kill on the White River and pollution-tolerant taxa again became the predominant benthic invertebrates present.

Historical fish-community data for the period 1999-2008 indicate that most of the study sites have fairly stable fish communities, with some minor variations from year to year. Only the Waverly site on the White River and the Pogues Run tributary site appear to have downward trends in IBI scores. Median IBI scores show that the Harding and Waverly sites on the White River and the Pleasant Run and Pogues Run tributary sites have the poorest fish-community conditions overall. 


\section{Acknowledgments}

The author thanks everyone who assisted in the timely and successful completion of this project. Especially noteworthy in this regard are the USGS employees who worked with such dedication toward this goal. Amanda Egler and Chad Menke were especially helpful with the benthic-invertebrate and fish-community fieldwork associated with this project. Amanda Egler was also instrumental in collecting and processing the streambed sediments for analysis. Brian Caskey and Jeffrey Frey assisted with the electrofishing activities.

\section{References Cited}

Benke, A.C., and Wallace, J.B., 1997, Trophic basis of production among riverine caddisflies - Implications for food web analysis: Ecology, v. 78, p. 1,132-1,145.

Britton, L.J., and Greeson, P.E., eds., 1989, Methods for collection and analysis of aquatic biological and microbiological samples: U.S. Geological Survey Techniques of WaterResources Investigations, book 5, chap. A4, p. 37-40.

Canadian Council of Ministers of the Environment, 1995, Protocol for the derivation of Canadian sediment quality guidelines for the protection of aquatic life: Winnipeg, Manitoba, prepared by the Technical Secretariat of the Water Quality Guidelines Task Group, Report CCMEEPC-98E, 38 p.

City of Indianapolis, 2000, Improving our streams in the City of Indianapolis, a report on options for controlling combined sewer overflows: Prepared by Quandt Engineering; Camp, Dresser \& McKee Inc.; and Greeley and Hansen Engineers, accessed March 15, 2001, at www.indygov.org/ dpw/cso/cso plan/index.htm.

City of Indianapolis, 2007, Wastewater management: Department of Public Works, accessed April 29, 2008, at http:// www.indygov.org/eGov/City/DPW/Environment/Wastewater/ home.htm.

Crawford, C.G., Wangsness, D.J., and Martin, J.D., 1992, Recovery of benthic-invertebrate communities in the White River near Indianapolis, Indiana, USA, following implementation of advanced treatment of municipal wastewater: Archiv für Hydrobiologie, v. 126, p. 67-84.

Crowder, L.B., 1990, Community ecology, in Schreck, C.B., and Moyle, P.B., eds., Methods for fish biology: Bethesda, Md., American Fisheries Society, p. 609-632.

Hilsenhoff, W.L., 1987, An improved biotic index of organic stream pollution: Great Lakes Entomologist, v. 20, no. 1, p. 31-39.
Hoggatt, R.E., 1975, Drainage areas of Indiana streams: U.S. Geological Survey, Water Resources Division, 321 p.

Indiana Department of Environmental Management, 2000, Executive summary of the case filed by Indiana and the U.S. EPA against Guide and Crown, accessed June 19, 2003, at http://www.in.gov/idem/mycommunity/wrcac/whiteriver/summary.html.

Karr, J.R., and Dudley, D.R., 1981, Ecological perspectives on water quality: Environmental Management, v. 5, p. 55-68.

Koryak, M., and Stafford, L.J., 2002, Aquatic invertebrate biological assessments, Phase 1, interim report, October 2001: Pittsburgh, Pa., Carnegie Mellon University, Studio for Creative Inquiry, $56 \mathrm{p}$.

MacDonald, D.D., Ingersoll, C.G., and Berger, T.A., 2000, Development and evaluation of consensus-based sediment quality guidelines for freshwater ecosystems: Archives of Environmental Contamination and Toxicology, v. 39, p. 20-31.

Mahler, B.J., and Van Metre, P.C., 2011, Coal-tar-based pavement sealcoat, polycyclic aromatic hydrocarbons (PAHs), and environmental health: U.S. Geological Survey Fact Sheet 2011-3010, 6 p.

Meador, M.R., Cuffney, T.F., and Gurtz, M.E., 1993, Methods for sampling fish communities as part of the National Water-Quality Assessment Program: U.S. Geological Survey Open-File Report 93-104, 40 p.

Medeiros, C., Leblanc, R., and Coler, R.A., 1983, An in situ assessment of the acute toxicity of urban runoff to benthic macroinvertebrates: Environmental Toxicology and Chemistry, v. 2, p. 119-126.

Nelson, J.S., Crossman, E.J., Espinosa-Pérez, H., Findley, L.T., Gilbert, C.R., Lea, R.N. and Williams. J.D., 2004, Common and scientific names of fishes from the United States, Canada, and Mexico (6th ed.): Bethesda, Md., American Fisheries Society, Special Publication 29, 386 p.

Newman, J.E., 1966, Bioclimate, in Lindsey, A.A., ed., Natural features of Indiana: Indianapolis, Indiana Academy of Science and Indiana State Library, p. 171-180.

Ohio Environmental Protection Agency, 1987, Biological criteria for the protection of aquatic life-Volume II, Users manual for biological field assessment of Ohio surface waters: Ohio Environmental Protection Agency [variously paged]. 
Ohio Environmental Protection Agency, 1989 (1st update), Biological criteria for the protection of aquatic life-Volume III, Standardized biological field sampling and laboratory methods for assessing fish and macroinvertebrate communities: Ohio Environmental Protection Agency [variously paged].

Paul, M.J., and Meyer, J.L., 2001, Streams in the urban landscape: Annual Review of Ecology and Systematics, v. 32, p. 333-365.

Pratt, J.M., Coler, R.A., and Godfrey, P.J., 1981, Ecological effects of urban stormwater runoff on benthic macroinvertebrates inhabiting the Green River, Massachusetts: Hydrobiologia, v. 83, p. 29-42.

Radtke, D.B., 2005, Bottom-material samples (ver. 1.1): U.S. Geological Survey Techniques of Water-Resources Investigations, book 9, chap. A8, accessed January 24, 2008, at http://water.usgs.gov/owq/FieldManual/Chapter8/ index.html.

Reece, P.F., and Richardson, J.S., 2000, Benthic macroinvertebrate assemblages of coastal and continental streams and large rivers of southwestern British Columbia, Canada: Hydrobiologia, v. 439, p. 77-89.

Renn, D.E., 1998, Benthic-invertebrate and streambed-sediment data for the White River and its tributaries in and near Indianapolis, Indiana, 1994-96: U.S. Geological Survey Open-File Report 98-533, 159 p.

Rochfort, Q., Grapentine, L., Marsalek, J., Brownlee, B., Reynoldson, T., Thompson, S., Milania, D., and Logan, C., 2000, Using benthic assessment techniques to determine combined sewer overflow and stormwater impacts in the aquatic ecosystem: Water Quality Research Journal of Canada, v. 35 no. 3, p. 365-397.

Shelton, L.R., and Capel, P.D., 1994, Guidelines for collecting and processing samples of stream and sediment for analysis of trace elements and organic contaminants for the National Water-Quality Assessment Program: U.S. Geological Survey Open-File Report 94-458, 20 p.
Simon, T.P., and Dufour, Ronda, 1998, Development of index of biotic integrity expectations for the ecoregions of Indiana-V, Eastern Corn Belt Plain: Chicago, Ill., U.S. Environmental Protection Agency, EPA 905/R-96/004, $68 \mathrm{p}$.

State of Indiana, 1996, Combined sewer overflow strategy: Indiana Department of Environmental Management, Office of Water Quality, Pretreatment and Urban Wet Weather Section, CSO group, $15 \mathrm{p}$.

U.S. Environmental Protection Agency, 1999, Combined sewer overflows, Guidance for monitoring and modeling, EPA 832-B-99-002 [variously paged], accessed January 23, 2008, at http://www.epa.gov/npdes/pubs/sewer. $p d f$.

U.S. Environmental Protection Agency, 2002, Clean Water Act, accessed March 4, 2003, at http://www.epa.gov/ region5/water/cwa.htm.

Verschueren, Karel, 1983, Handbook of environmental data on organic chemicals ( $2 \mathrm{~d}$ ed.): New York, Van Nostrand Reinhold, 1,310 p.

Voelker, D.C., 2004, Biological assessment of streams in the Indianapolis metropolitan area, Indiana, 1999-2001: U.S. Geological Survey Water-Resources Investigations Report 03-4331, 48 p. (plus CD-ROM with appendix data).

Voelker, D.C., and Renn, D.E., 2000, Benthic invertebrates and quality of streambed sediments in the White River and selected tributaries in and near Indianapolis, Indiana, 1994-96: U.S. Geological Survey Water-Resources Investigations Report 99-4276, 52 p.

Woods, A.J., Omernik, J.M., Brockman, C.S., Gerber, T.D., Hosteter, W.D., and Azevedo, S.H., 1998, Ecoregions of Indiana and Ohio: Scale, 1:1,500,000, accessed January 24, 2008, at ftp://ftp.epa.gov/wed/ecoregions/oh_in/Ohio_eco_ lg.pdf. 



\section{Supplemental Data}



Table 3. Benthic-invertebrate taxa collected at all sites in the Indianapolis metropolitan area, 2003-2008.

[sp., species; cf., closely comparable to; w.h.c., with hair chaetae; w.o.h.c., without hair chaetae; gp., group]

\begin{tabular}{|c|c|c|c|c|}
\hline Phylum & Class & Order & Family & Taxon \\
\hline Coelenterata & Hydrozoa & Hydroida & Hydridae & Hydra americana \\
\hline Platyhelminthes & Turbellaria & Tricladida & Planariidae & Cura foremanii \\
\hline Platyhelminthes & Turbellaria & Tricladida & Dugesiidae & Girardia tigrina \\
\hline Nematoda & unidentified & unidentified & unidentified & unidentified \\
\hline Mollusca & Bivalvia & Veneroida & Corbiculidae & Corbicula fluminea \\
\hline Mollusca & Bivalvia & Veneroida & Sphaeriidae & Pisidium sp. \\
\hline Mollusca & Bivalvia & Veneroida & Sphaeriidae & Sphaerium cf. simile \\
\hline Mollusca & Gastropoda & Mesogastropoda & Hydrobiidae & Amnicola sp. \\
\hline Mollusca & Gastropoda & Mesogastropoda & Hydrobiidae & Somatogyrus sp. \\
\hline Mollusca & Gastropoda & Mesogastropoda & Pleuroceridae & Elimia sp. \\
\hline Mollusca & Gastropoda & Basommatophora & Lymnaeidae & Fossaria sp. \\
\hline Mollusca & Gastropoda & Basommatophora & Planorbidae & Gyraulus parvus \\
\hline Mollusca & Gastropoda & Basommatophora & Planorbidae & Menetus dilatatus \\
\hline Mollusca & Gastropoda & Basommatophora & Physidae & Physella sp. \\
\hline Annelida & Oligochaeta & Haplotaxida & Enchytraeidae & unidentified \\
\hline Annelida & Oligochaeta & Lumbriculida & Lumbriculidae & Lumbriculus sp. \\
\hline Annelida & Oligochaeta & Lumbriculida & Lumbricidae & unidentified \\
\hline Annelida & Oligochaeta & Tubificida & Naididae & Chaetogaster sp. \\
\hline Annelida & Oligochaeta & Tubificida & Naididae & Dero sp. \\
\hline Annelida & Oligochaeta & Tubificida & Naididae & Nais bretscheri \\
\hline Annelida & Oligochaeta & Tubificida & Tubificidae w.o.h.c. & Branchiura sowerbyi \\
\hline Annelida & Oligochaeta & Tubificida & Tubificidae w.o.h.c. & Limnodrilus claparedianus \\
\hline Annelida & Oligochaeta & Tubificida & Tubificidae w.o.h.c. & Limnodrilus hoffmeisteri \\
\hline Annelida & Hirudinea & Branchiobdellida & unidentified & unidentified \\
\hline Annelida & Hirudinea & Arhynchobdellida & Erpobdellidae & unidentified \\
\hline Annelida & Hirudinea & Rhynchobdellida & Glossiphoniidae & Helobdella stagnalis \\
\hline Annelida & Hirudinea & Rhynchobdellida & Glossiphoniidae & Helobdella triserialis \\
\hline Annelida & Hirudinea & Rhynchobdellida & Glossiphoniidae & Placobdella parasitica \\
\hline Arthropoda & Arachnoidea & Acariformes & Hygrobatidae & Atractides sp. \\
\hline Arthropoda & Arachnoidea & Acariformes & Lebertiidae & Lebertia sp. \\
\hline Arthropoda & Crustacea & Ostracoda & unidentified & unidentified \\
\hline Arthropoda & Crustacea & Cladocera & Chydoridae & Chydorus sp. \\
\hline Arthropoda & Crustacea & Cladocera & Daphnidae & Ceriodaphnia sp. \\
\hline Arthropoda & Crustacea & Cladocera & Daphnidae & Daphnia sp. \\
\hline Arthropoda & Crustacea & Cladocera & Sididae & Sida crystillina \\
\hline Arthropoda & Crustacea & Copepoda & unidentified & unidentified \\
\hline Arthropoda & Crustacea & Calanoida & unidentified & unidentified \\
\hline
\end{tabular}


Table 3. Benthic-invertebrate taxa collected at all sites in the Indianapolis metropolitan area, 2003-2008.-Continued

[sp., species; cf., closely comparable to; w.h.c., with hair chaetae; w.o.h.c., without hair chaetae; gp., group]

\begin{tabular}{|c|c|c|c|c|}
\hline Phylum & Class & Order & Family & Taxon \\
\hline Arthropoda & Crustacea & Cyclopoida & unidentified & unidentified \\
\hline Arthropoda & Crustacea & Isopoda & Asellidae & Caecidotea sp. \\
\hline Arthropoda & Crustacea & Isopoda & Asellidae & Lirceus sp. \\
\hline Arthropoda & Crustacea & Amphipoda & Crangonyctidae & Crangonyx sp. \\
\hline Arthropoda & Crustacea & Amphipoda & Gammaridae & Gammarus sp. \\
\hline Arthropoda & Crustacea & Amphipoda & Talitridae & Hyalella azteca \\
\hline Arthropoda & Crustacea & Decapoda & Cambaridae & Orconectes sp. \\
\hline Arthropoda & Insecta & Collembola & Isotomidae & unidentified \\
\hline Arthropoda & Insecta & Ephemeroptera & Baetidae & Acentrella ampla \\
\hline Arthropoda & Insecta & Ephemeroptera & Baetidae & Baetis cf. flavistringa \\
\hline Arthropoda & Insecta & Ephemeroptera & Baetidae & Baetis intercalaris \\
\hline Arthropoda & Insecta & Ephemeroptera & Baetidae & Heterocloeon sp. \\
\hline Arthropoda & Insecta & Ephemeroptera & Baetidae & Plauditus sp. \\
\hline Arthropoda & Insecta & Ephemeroptera & Caenidae & Caenis sp. \\
\hline Arthropoda & Insecta & Ephemeroptera & Heptageniidae & Heptagenia sp. \\
\hline Arthropoda & Insecta & Ephemeroptera & Heptageniidae & Leucrocuta sp. \\
\hline Arthropoda & Insecta & Ephemeroptera & Heptageniidae & Maccaffertium (Stenonema) exiguum \\
\hline Arthropoda & Insecta & Ephemeroptera & Heptageniidae & Maccaffertium (Stenonema) femoratum \\
\hline Arthropoda & Insecta & Ephemeroptera & Heptageniidae & $\begin{array}{l}\text { Maccaffertium (Stenonema) } \\
\text { mediopunctatum }\end{array}$ \\
\hline Arthropoda & Insecta & Ephemeroptera & Heptageniidae & Maccaffertium (Stenonema) terminatum \\
\hline Arthropoda & Insecta & Ephemeroptera & Heptageniidae & Stenacron interpunctatum \\
\hline Arthropoda & Insecta & Ephemeroptera & Heptageniidae & Stenonema femoratum \\
\hline Arthropoda & Insecta & Ephemeroptera & Heptageniidae & Stenonema integrum \\
\hline Arthropoda & Insecta & Ephemeroptera & Heptageniidae & Stenonema terminatum \\
\hline Arthropoda & Insecta & Ephemeroptera & Isonychiidae & Isonychia sp. \\
\hline Arthropoda & Insecta & Ephemeroptera & Leptophlebiidae & Paraleptophlebia sp. \\
\hline Arthropoda & Insecta & Ephemeroptera & Polymitarcyidae & Ephoron leukon \\
\hline Arthropoda & Insecta & Ephemeroptera & Potamanthidae & Anthopotamus sp. \\
\hline Arthropoda & Insecta & Ephemeroptera & Potamanthidae & Anthopotamus myops \\
\hline Arthropoda & Insecta & Ephemeroptera & Tricorythidae & Tricorythodes sp. \\
\hline Arthropoda & Insecta & Odonata & Calopterygidae & Calopteryx sp. \\
\hline Arthropoda & Insecta & Odonata & Calopterygidae & unidentified \\
\hline Arthropoda & Insecta & Odonata & Coenagrionidae & Argia sp. \\
\hline Arthropoda & Insecta & Odonata & Coenagrionidae & Enallagma sp. \\
\hline Arthropoda & Insecta & Odonata & Coenagrionidae & Ischnura sp. \\
\hline Arthropoda & Insecta & Odonata & Corduliidae & Neurocordulia sp. \\
\hline Arthropoda & Insecta & Odonata & Gomphidae & Erpetogomphus sp. \\
\hline Arthropoda & Insecta & Odonata & Gomphidae & Erpetogomphus designatus \\
\hline Arthropoda & Insecta & Odonata & Gomphidae & Gomphus sp. \\
\hline Arthropoda & Insecta & Odonata & Gomphidae & Ophiogomphus/Erpetogomphus sp. \\
\hline Arthropoda & Insecta & Odonata & Libellulidae & Libellula $\mathrm{sp}$. \\
\hline Arthropoda & Insecta & Plecoptera & Leuctridae & Leuctra sp. \\
\hline Arthropoda & Insecta & Plecoptera & Perlidae & Neoperla sp. \\
\hline Arthropoda & Insecta & Plecoptera & Perlidae & Perlesta placida \\
\hline Arthropoda & Insecta & Plecoptera & Perlidae & Perlinella ephyre \\
\hline Arthropoda & Insecta & Plecoptera & Perlodidae & unidentified \\
\hline Arthropoda & Insecta & Plecoptera & Taeniopterygidae & Taeniopteryx sp. \\
\hline Arthropoda & Insecta & Hemiptera & Corixidae & unidentified \\
\hline
\end{tabular}


Table 3. Benthic-invertebrate taxa collected at all sites in the Indianapolis metropolitan area, 2003-2008.-Continued

[sp., species; cf., closely comparable to; w.h.c., with hair chaetae; w.o.h.c., without hair chaetae; gp., group]

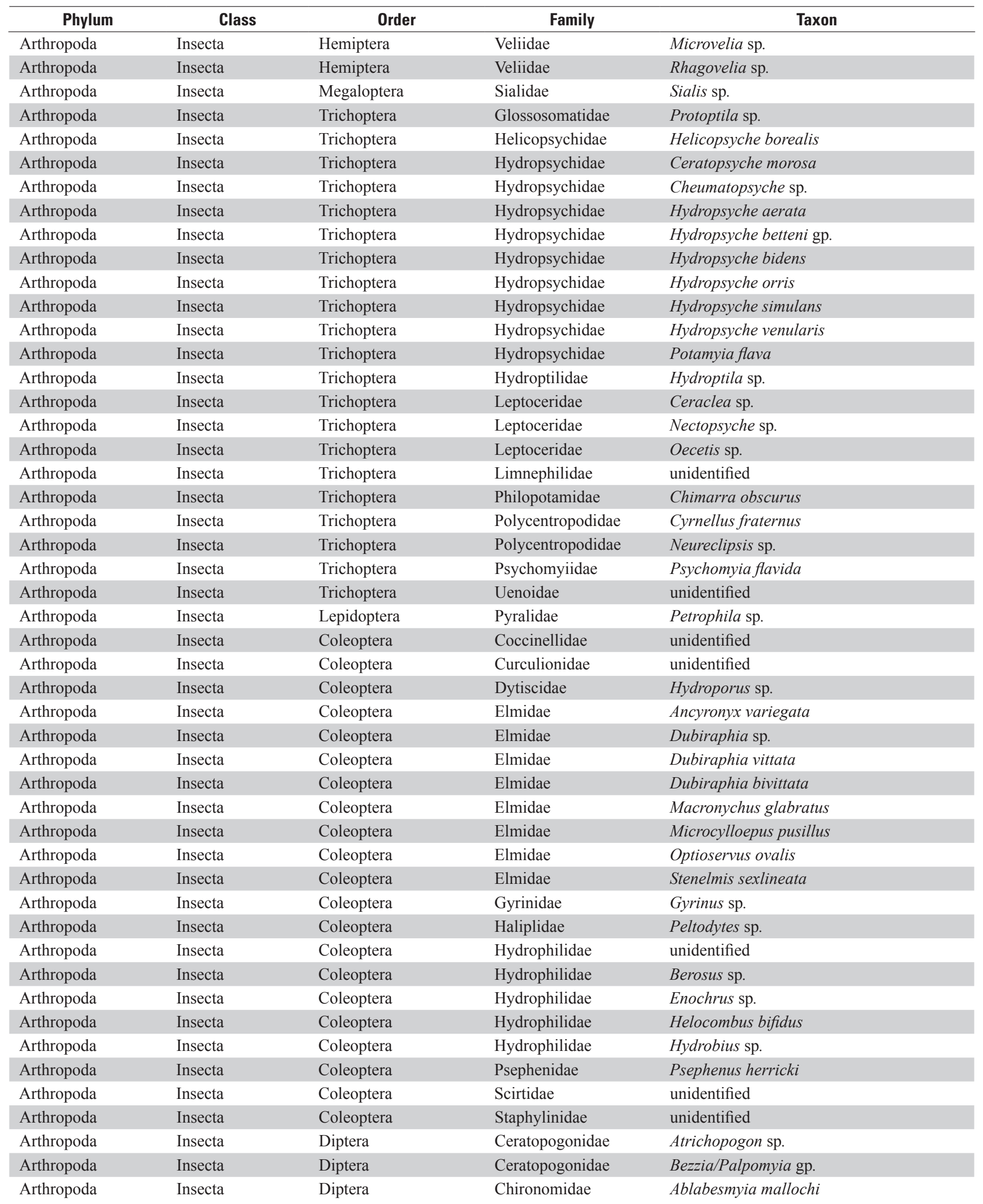


Table 3. Benthic-invertebrate taxa collected at all sites in the Indianapolis metropolitan area, 2003-2008.—Continued

[sp., species; cf., closely comparable to; w.h.c., with hair chaetae; w.o.h.c., without hair chaetae; gp., group]

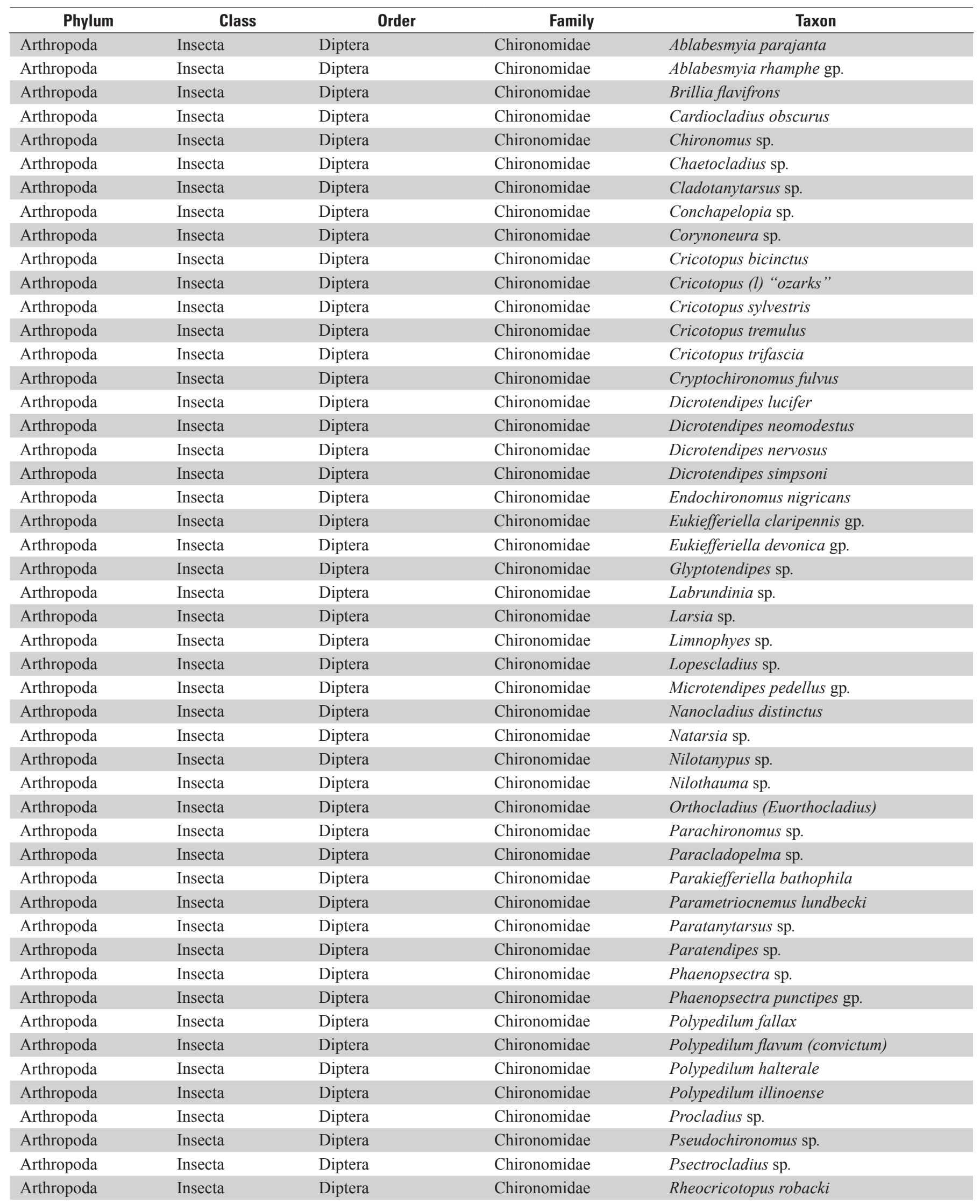


Table 3. Benthic-invertebrate taxa collected at all sites in the Indianapolis metropolitan area, 2003-2008.-Continued

[sp., species; cf., closely comparable to; w.h.c., with hair chaetae; w.o.h.c., without hair chaetae; gp., group]

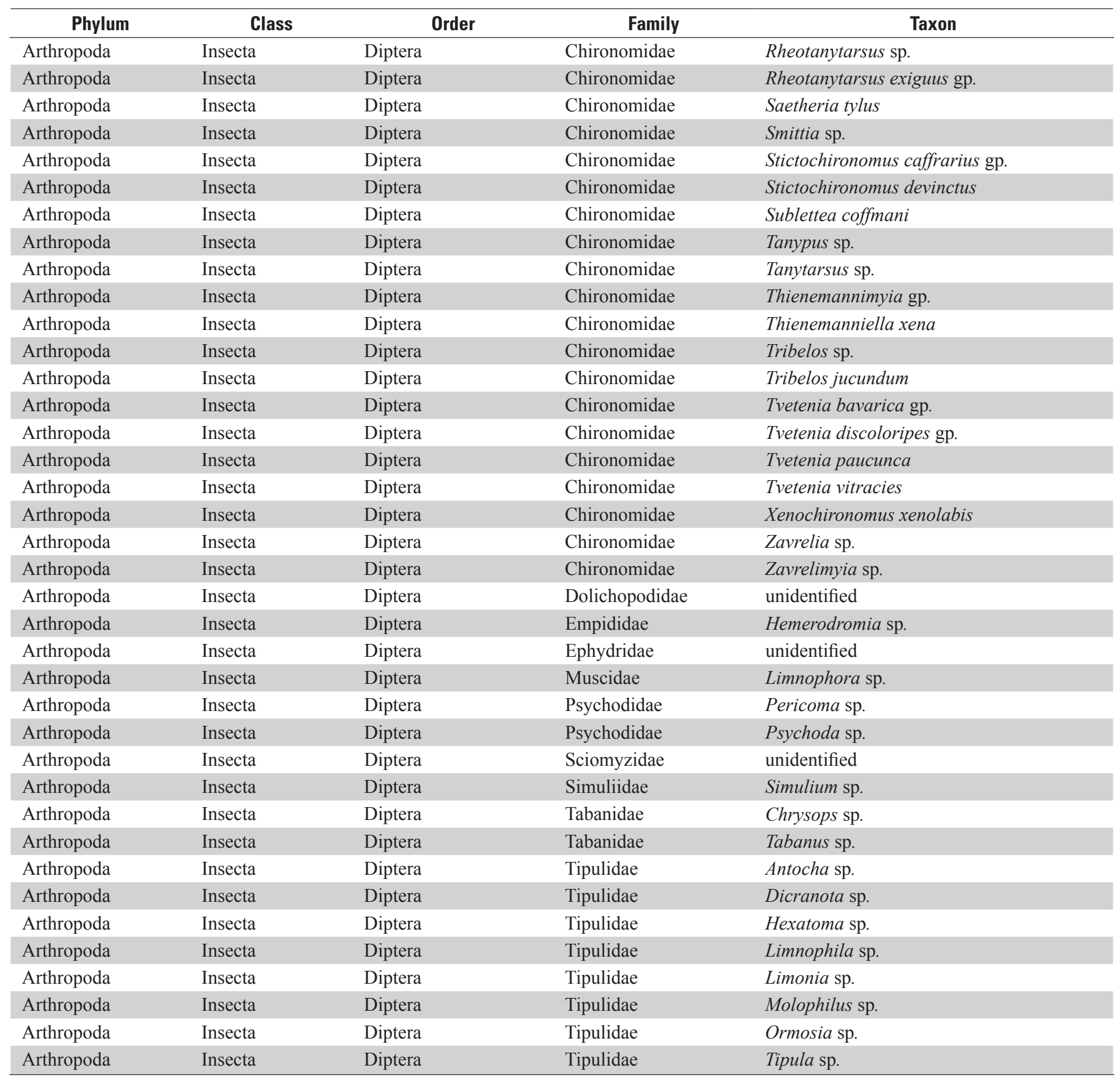


[N, non-native species deliberately or accidentally introduced into the basin; --, not found]

\begin{tabular}{|c|c|c|c|c|c|c|c|c|c|c|c|c|c|c|c|}
\hline \multirow{3}{*}{ Scientific name } & \multirow{3}{*}{$\begin{array}{l}\text { Common name } \\
\text { and status }\end{array}$} & \multicolumn{14}{|c|}{ Number of fish collected at White River sites } \\
\hline & & \multicolumn{2}{|c|}{ Nora } & \multicolumn{2}{|c|}{ Morris } & \multicolumn{2}{|c|}{ Harding } & \multicolumn{2}{|c|}{ Stout } & \multicolumn{2}{|c|}{ Tibbs } & \multicolumn{2}{|c|}{ Wicker } & \multicolumn{2}{|c|}{ Waverly } \\
\hline & & 2006 & 2008 & 2006 & 2008 & 2006 & 2008 & 2006 & 2008 & 2006 & 2008 & 2006 & 2008 & 2006 & 2008 \\
\hline Lepisosteidae & (gars) & & & & & & & & & & & & & & \\
\hline${\text { Lepisosteus osseus (Linnaeus, } 1758)^{1}}^{1}$ & longnose gar & -- & -- & -- & -- & -- & -- & -- & -- & 2 & -- & -- & -- & -- & -- \\
\hline Clupeidae & (herrings) & & & & & & & & & & & & & & \\
\hline Dorosoma cepedianum (Lesueur, 1818) & gizzard shad & 9 & 3 & 8 & 3 & 14 & 2 & -- & 4 & 16 & 4 & 7 & 1 & 6 & -- \\
\hline Cyprinidae & (carps and minnows) & & & & & & & & & & & & & & \\
\hline Campostoma anomalum (Rafinesque, 1820) & central stoneroller & 14 & -- & -- & -- & -- & -- & -- & 1 & 7 & 66 & 12 & 2 & -- & -- \\
\hline Cyprinella spiloptera $($ Cope, 1868$)$ & spotfin shiner & 21 & 3 & 18 & -- & 11 & 4 & 22 & 34 & 43 & 26 & 4 & 60 & 1 & 6 \\
\hline Cyprinus carpio Linnaeus, 1758 & common carp $\mathbf{N}$ & 2 & 1 & 1 & 5 & 3 & 8 & 2 & 14 & 2 & 2 & 5 & 1 & 11 & 16 \\
\hline Luxilus chrysocephalus Rafinesque, 1820 & striped shiner & -- & -- & -- & -- & -- & -- & -- & -- & 2 & -- & -- & -- & -- & -- \\
\hline Lythrusus umbratilus (Girard, 1856) & redfin shiner & -- & -- & -- & 4 & -- & -- & -- & -- & -- & -- & -- & -- & -- & -- \\
\hline Notemigonus crysoleucas (Mitchill, 1814) & golden shiner & -- & -- & -- & 2 & -- & 15 & -- & -- & -- & -- & -- & -- & -- & -- \\
\hline Notropis buccatus (Cope, 1865) & silverjaw minnow & -- & -- & -- & -- & -- & -- & -- & -- & 3 & -- & 2 & -- & -- & -- \\
\hline Notropis photogenis (Cope, 1865) & silver shiner & 1 & 1 & -- & -- & -- & -- & -- & -- & -- & 1 & -- & -- & -- & -- \\
\hline Notropis stramineus (Cope, 1865) & sand shiner & 6 & -- & -- & -- & -- & 1 & 28 & 23 & 65 & 369 & 24 & 230 & -- & -- \\
\hline Phenacobius mirabilis (Girard, 1856) & suckermouth minnow & -- & -- & -- & -- & -- & -- & -- & 2 & 6 & 18 & -- & -- & -- & -- \\
\hline Pimephales notatus (Rafinesque, 1820) & bluntnose minnow & 1 & -- & 7 & -- & -- & 1 & 1 & 14 & 1 & 15 & -- & 6 & -- & -- \\
\hline Pimephales vigilax (Baird \& Girard, 1853) & bullhead minnow & -- & -- & -- & -- & -- & -- & 2 & -- & -- & -- & -- & -- & -- & -- \\
\hline Semotilus atromaculatus (Mitchill, 1818) & creek chub & 2 & -- & -- & -- & -- & -- & -- & -- & -- & -- & 2 & -- & -- & -- \\
\hline Catostomidae & (suckers and buffalo) & & & & & & & & & & & & & & \\
\hline Carpiodes carpio (Rafinesque, 1820) & river carpsucker & -- & -- & 8 & 11 & 13 & 5 & 6 & 19 & 7 & 4 & 5 & 4 & 31 & 18 \\
\hline Carpiodes cyprinus (Lesueur, 1817) & quillback & -- & -- & -- & -- & 1 & -- & -- & -- & 3 & -- & 2 & -- & 2 & -- \\
\hline Carpiodes velifer (Rafinesque, 1820) & highfin carpsucker & -- & -- & -- & 1 & -- & 1 & -- & 4 & -- & 1 & 2 & 1 & -- & -- \\
\hline Catostomus commersonii (Lacepede, 1803) & white sucker & 1 & -- & 1 & -- & 1 & -- & -- & -- & -- & -- & -- & -- & -- & -- \\
\hline Hypentelium nigricans (Lesueur, 1817) & northern hog sucker & 11 & 11 & 7 & 3 & -- & -- & 35 & 32 & 43 & 29 & 24 & 18 & -- & -- \\
\hline Ictiobus bubalus (Rafinesque, 1818) & smallmouth buffalo & -- & -- & -- & 1 & 1 & 2 & 1 & -- & -- & -- & -- & -- & 2 & -- \\
\hline Ictiobus cyprinellus (Valenciennes, 1844) & bigmouth buffalo & -- & -- & 1 & -- & 1 & -- & 1 & -- & -- & -- & -- & -- & -- & -- \\
\hline Minytrema melanops (Rafinesque, 1820) & spotted sucker & 2 & 2 & 6 & 13 & 5 & 10 & -- & 1 & -- & -- & -- & -- & 3 & -- \\
\hline Moxostoma anisurum (Rafinesque, 1820) & silver redhorse & -- & 1 & -- & 6 & -- & 1 & 2 & 5 & 11 & 3 & 15 & 14 & 12 & 1 \\
\hline Moxostoma duquesnei (Lesueur, 1817) & black redhorse & -- & 2 & -- & 14 & -- & 2 & -- & -- & -- & 4 & 1 & 1 & 1 & -- \\
\hline Moxostoma erythrurum (Rafinesque, 1818) & golden redhorse & 8 & 10 & 6 & 13 & 3 & 1 & 7 & 3 & -- & 2 & 1 & 14 & -- & 3 \\
\hline Moxostoma macrolepidotum (Lesueur, 1817) & shorthead redhorse & -- & -- & -- & 7 & -- & -- & 5 & 21 & 17 & 17 & 8 & 17 & 2 & 23 \\
\hline Ictaluridae & (bullhead and catfishes) & & & & & & & & & & & & & & \\
\hline Ictalurus punctatus (Rafinesque, 1818) & channel catfish & 3 & 8 & 8 & 7 & 4 & 8 & 24 & 4 & 10 & 2 & 1 & 1 & 9 & 3 \\
\hline Noturus flavus Rafinesque & stonecat & -- & -- & -- & -- & -- & -- & -- & -- & -- & 1 & -- & -- & -- & -- \\
\hline Pylodictis olivaris (Rafinesque, 1818) & flathead catfish & 1 & -- & 1 & -- & 2 & -- & -- & -- & -- & -- & 1 & -- & 2 & 3 \\
\hline
\end{tabular}


Table 7. Fish collected at the White River sites in the Indianapolis metropolitan area, 2006 and 2008.-Continued

[N, non-native species deliberately or accidentally introduced into the basin; --, not found]

\begin{tabular}{|c|c|c|c|c|c|c|c|c|c|c|c|c|c|c|c|}
\hline \multirow{3}{*}{ Scientific name } & \multirow{3}{*}{$\begin{array}{l}\text { Common name } \\
\text { and status }\end{array}$} & \multicolumn{14}{|c|}{ Number of fish collected at White River sites } \\
\hline & & \multicolumn{2}{|c|}{ Nora } & \multicolumn{2}{|c|}{ Morris } & \multicolumn{2}{|c|}{ Harding } & \multicolumn{2}{|c|}{ Stout } & \multicolumn{2}{|c|}{ Tibbs } & \multicolumn{2}{|c|}{ Wicker } & \multicolumn{2}{|c|}{ Waverly } \\
\hline & & 2006 & 2008 & 2006 & 2008 & 2006 & 2008 & 2006 & 2008 & 2006 & 2008 & 2006 & 2008 & 2006 & 2008 \\
\hline Poeciliidae & (live bearers) & & & & & & & & & & & & & & \\
\hline Gambusia affinis (Baird and Girard, 1853) & western mosquitofish $\mathbf{N}$ & -- & -- & -- & -- & -- & -- & -- & -- & -- & -- & 4 & -- & -- & -- \\
\hline Atherinidae & (silversides) & & & & & & & & & & & & & & \\
\hline Labidesthes sicculus (Cope, 1865) & brook silverside & -- & -- & -- & -- & -- & -- & -- & 3 & 7 & -- & -- & -- & -- & -- \\
\hline Centrarchidae & (sunfishes) & & & & & & & & & & & & & & \\
\hline Ambloplites rupestris (Rafinesque, 1817) & rock bass & 1 & 5 & 1 & 3 & -- & 1 & -- & 1 & -- & -- & -- & -- & -- & -- \\
\hline Lepomis cyanellus Rafinesque, 1819 & green sunfish & 1 & 1 & -- & 2 & -- & -- & -- & -- & -- & -- & -- & -- & -- & -- \\
\hline Lepomis humilis (Girard, 1858) & orangespotted sunfish & -- & -- & -- & -- & -- & 1 & -- & -- & -- & -- & -- & -- & -- & -- \\
\hline Lepomis macrochirus Rafinesque, 1819 & bluegill & 30 & 86 & 14 & 58 & 9 & 44 & 12 & 43 & 6 & 7 & 3 & 2 & 6 & 20 \\
\hline Lepomis megalotis (Rafinesque, 1820) & longear sunfish & 12 & 31 & 23 & 164 & 20 & 54 & 12 & 82 & 3 & 4 & 1 & 4 & 4 & 46 \\
\hline Lepomis macrochirus $\times$ Lepomis megalotis & $\begin{array}{l}\text { HYBRID bluegill } \times \text { longear } \\
\text { sunfish }\end{array}$ & 3 & -- & -- & -- & -- & -- & -- & -- & -- & -- & -- & -- & -- & -- \\
\hline Lepomis microlophus (Gunther, 1859) & redear sunfish & -- & 1 & -- & -- & -- & -- & 2 & 1 & -- & -- & -- & 1 & 1 & -- \\
\hline Micropterus dolomieu Lacepede, 1802 & smallmouth bass & 8 & 14 & 3 & 12 & 2 & -- & 1 & 3 & 6 & 4 & 4 & 5 & 3 & 4 \\
\hline Micropterus punctulatus (Rafinesque, 1819) & spotted bass & -- & 9 & 2 & 5 & 1 & 4 & 2 & 2 & -- & 4 & -- & 2 & 6 & 8 \\
\hline Micropterus salmoides (Lacepede, 1802) & largemouth bass & 23 & 3 & -- & 11 & 4 & 13 & 5 & 9 & 6 & 2 & 3 & - & 2 & 2 \\
\hline Pomoxis annularis Rafinesque, 1818 & white crappie & -- & 1 & -- & 1 & -- & -- & -- & 2 & -- & -- & -- & -- & 2 & 1 \\
\hline Pomoxis nigromaculatus (Lesueur, 1829) & black crappie & 1 & 1 & -- & 5 & -- & 2 & 4 & 7 & -- & -- & -- & -- & -- & 2 \\
\hline Percidae & (perches and darters) & & & & & & & & & & & & & & \\
\hline Etheostoma blennioides Rafinesque, 1820 & greenside darter & -- & 2 & -- & 1 & -- & -- & -- & -- & -- & -- & -- & -- & -- & -- \\
\hline Etheostoma caeruleum Storer & rainbow darter & -- & -- & -- & -- & -- & -- & -- & -- & -- & -- & -- & 1 & -- & -- \\
\hline Etheostoma spectabile (Agassiz, 1854) & orangethroat darter & -- & -- & -- & -- & -- & -- & -- & -- & 1 & -- & -- & -- & -- & -- \\
\hline Percina caprodes (Rafinesque, 1818) & logperch & 12 & 8 & 5 & 3 & -- & 2 & 3 & 10 & -- & -- & -- & 6 & -- & -- \\
\hline Sander canadense (Smith, 1834) & sauger & 3 & 1 & -- & -- & -- & -- & -- & -- & 1 & -- & -- & -- & 1 & 1 \\
\hline Sander vitreus (Mitchill, 1818) & walleye & -- & -- & -- & -- & -- & -- & -- & -- & 1 & -- & 1 & -- & 1 & -- \\
\hline Sciaenidae & (drums) & & & & & & & & & & & & & & \\
\hline Aplodinotus grunniens Rafinesque, 1819 & freshwater drum & -- & -- & -- & -- & -- & 2 & 1 & 2 & -- & 2 & -- & -- & 2 & -- \\
\hline & Total number of fish: & 176 & 205 & 120 & 355 & 95 & 184 & 178 & 346 & 269 & 587 & 132 & 391 & 110 & 157 \\
\hline & Number of species: & 24 & 23 & 18 & 25 & 17 & 23 & 22 & 27 & 24 & 23 & 23 & 21 & 22 & 16 \\
\hline & Total weight, in kilograms: & 27.3 & 41.5 & 32.0 & 42.8 & 36.8 & 47.7 & 47.2 & 60.1 & 47.7 & 22.8 & 38.9 & 18.0 & 79.6 & 82.5 \\
\hline
\end{tabular}

${ }^{1}$ Authority and date of the original published proposal of the scientific name. The author's name follows the scientific name and without parenthesis if the species, when originally described, was assigned to the same genus in which it appears; if the species was described in another genus, the author's name appears in parenthesis (Robins and others, 1991). 
[N, non-native species deliberately or accidentally introduced into the basin; --, not found]

\begin{tabular}{|c|c|c|c|c|c|c|c|c|c|c|c|c|c|}
\hline \multirow{3}{*}{ Scientific name } & \multirow{3}{*}{$\begin{array}{l}\text { Common name } \\
\text { and status }\end{array}$} & \multicolumn{12}{|c|}{ Number of fish collected at tributary sites } \\
\hline & & \multicolumn{2}{|c|}{ Buck Creek } & \multicolumn{2}{|c|}{ Eagle Creek } & \multicolumn{2}{|c|}{ Fall Creek } & \multicolumn{2}{|c|}{ Pleasant Run } & \multicolumn{2}{|c|}{ Pogues Run } & \multicolumn{2}{|c|}{ Williams Creek } \\
\hline & & 2006 & 2008 & 2006 & 2008 & 2006 & 2008 & 2006 & 2008 & 2006 & 2008 & 2006 & 2008 \\
\hline Clupeidae & (herrings) & & & & & & & & & & & & \\
\hline Dorosoma cepedianum (Lesueur, 1818) ${ }^{1}$ & gizzard shad & -- & 2 & -- & -- & 5 & -- & -- & -- & -- & -- & 2 & 1 \\
\hline Cyprinidae & (carps and minnows) & & & & & & & & & & & & \\
\hline Campostoma anomalum (Rafinesque, 1820) & central stoneroller & 79 & 260 & -- & -- & 4 & 15 & 485 & 714 & 61 & 152 & 588 & 49 \\
\hline Cyprinella spiloptera (Cope, 1868$)$ & spotfin shiner & 24 & 2 & 30 & 4 & 67 & 13 & -- & 2 & -- & -- & -- & -- \\
\hline Cyprinus carpio Linnaeus, 1758 & common carp $\mathbf{N}$ & -- & -- & -- & 1 & 2 & -- & -- & -- & -- & -- & -- & -- \\
\hline Erimystax dissimilis (Kirtland, 1840) & streamline chub & 3 & 11 & -- & -- & -- & -- & -- & -- & -- & -- & -- & -- \\
\hline Hybopsis amblops (Rafinesque, 1820) & bigeye chub & -- & 2 & -- & -- & -- & -- & -- & -- & -- & -- & -- & -- \\
\hline Luxilus chrysocephalus Rafinesque, 1820 & striped shiner & 1 & 13 & -- & -- & -- & -- & -- & -- & -- & -- & 26 & 8 \\
\hline Nocomis micropogon (Cope, 1865) & river chub & -- & -- & -- & -- & 3 & 2 & -- & -- & -- & -- & -- & -- \\
\hline Notemigonus crysoleucas (Mitchill, 1814) & golden shiner & -- & -- & -- & -- & -- & 1 & -- & -- & -- & -- & -- & -- \\
\hline Notropis atherinoides Rafinesque, 1818 & emerald shiner & 18 & 7 & -- & -- & -- & -- & 31 & 64 & -- & -- & 2 & -- \\
\hline Notropis boops Gilbert, 1884 & bigeye shiner & 14 & -- & -- & -- & -- & -- & -- & -- & -- & -- & -- & -- \\
\hline Notropis buccatus (Cope, 1865) & silverjaw minnow & -- & 3 & 3 & 5 & -- & -- & 82 & 53 & 1 & 12 & -- & -- \\
\hline Notropis photogenis (Cope, 1865) & silver shiner & -- & -- & -- & -- & -- & -- & -- & 4 & -- & -- & -- & -- \\
\hline Notropis rubellus (Agissiz, 1850) & rosyface shiner & -- & -- & -- & -- & 3 & -- & -- & -- & -- & -- & -- & -- \\
\hline Notropis stramineus (Cope, 1865) & sand shiner & 5 & 45 & 62 & 50 & 86 & -- & 49 & 184 & -- & -- & -- & -- \\
\hline Phenacobius mirabilis (Girard, 1856) & suckermouth minnow & 2 & -- & -- & -- & 3 & -- & 1 & -- & -- & -- & -- & -- \\
\hline Pimephales notatus (Rafinesque, 1820) & bluntnose minnow & 61 & 85 & -- & 3 & 1 & 2 & 9 & 15 & 107 & 24 & 9 & -- \\
\hline Rhinichthys obtusus (Hermann, 1804) & western blacknose dace & -- & -- & -- & -- & -- & -- & 26 & -- & 43 & 23 & -- & -- \\
\hline Semotilus atromaculatus (Mitchill, 1818) & creek chub & 1 & 5 & -- & -- & -- & -- & 54 & 28 & 190 & 149 & 45 & 14 \\
\hline Catostomidae & (suckers and buffalo) & & & & & & & & & & & & \\
\hline Carpiodes cyprinus (Lesueur, 1817) & quillback & -- & -- & 6 & -- & -- & -- & -- & -- & -- & -- & -- & -- \\
\hline Catostomus commersonii (Lacepede, 1803) & white sucker & 6 & 1 & 2 & 3 & 1 & -- & 21 & 27 & -- & 27 & 24 & -- \\
\hline Hypentelium nigricans (Lesueur, 1817) & northern hog sucker & 39 & 30 & 2 & 14 & 29 & 8 & 1 & 10 & -- & -- & 31 & 7 \\
\hline Minytrema melanops (Rafinesque, 1820) & spotted sucker & 2 & 1 & -- & -- & -- & -- & -- & -- & -- & -- & -- & -- \\
\hline Moxostoma anisurum (Rafinesque, 1820) & silver redhorse & 25 & 8 & -- & -- & 13 & -- & -- & -- & -- & -- & -- & -- \\
\hline Moxostoma duquesnei (Lesueur, 1817) & black redhorse & -- & -- & 1 & -- & 10 & 13 & -- & -- & -- & -- & -- & -- \\
\hline Moxostoma erythrurum (Rafinesque, 1818) & golden redhorse & -- & 19 & -- & 1 & -- & 9 & -- & -- & -- & -- & -- & 2 \\
\hline Moxostoma macrolepidotum (Lesueur, 1817) & shorthead redhorse & 3 & 5 & -- & -- & -- & -- & -- & -- & -- & -- & -- & -- \\
\hline Ictaluridae & (bullhead and catfishes) & & & & & & & & & & & & \\
\hline Ameiurus natalis (Lesueur, 1819) & yellow bullhead & 1 & 1 & 2 & 3 & -- & 3 & 1 & 2 & 1 & 3 & -- & -- \\
\hline Ictalurus punctatus (Rafinesque, 1818) & channel catfish & -- & -- & 4 & 1 & -- & 1 & -- & -- & -- & -- & -- & -- \\
\hline Noturus flavus Rafinesque & stonecat & -- & -- & -- & -- & -- & 1 & -- & -- & -- & -- & -- & -- \\
\hline Pylodictis olivaris (Rafinesque, 1818) & flathead catfish & -- & -- & -- & -- & 1 & 1 & -- & -- & -- & -- & -- & -- \\
\hline
\end{tabular}


Table 8. Fish collected at the tributary sites in the Indianapolis metropolitan area, 2006 and 2008. - Continued

[N, non-native species deliberately or accidentally introduced into the basin; --, not found]

\begin{tabular}{|c|c|c|c|c|c|c|c|c|c|c|c|c|c|}
\hline \multirow{3}{*}{ Scientific name } & \multirow{3}{*}{$\begin{array}{l}\text { Common name } \\
\text { and status }\end{array}$} & \multicolumn{12}{|c|}{ Number of fish collected at tributary sites } \\
\hline & & \multicolumn{2}{|c|}{ Buck Creek } & \multicolumn{2}{|c|}{ Eagle Creek } & \multicolumn{2}{|c|}{ Fall Creek } & \multicolumn{2}{|c|}{ Pleasant Run } & \multicolumn{2}{|c|}{ Pogues Run } & \multicolumn{2}{|c|}{ Williams Creek } \\
\hline & & 2006 & 2008 & 2006 & 2008 & 2006 & 2008 & 2006 & 2008 & 2006 & 2008 & 2006 & 2008 \\
\hline Poeciliidae & (live bearers) & & & & & & & & & & & & \\
\hline Gambusia affinis (Baird and Girard, 1853) & western mosquitofish $\mathbf{N}$ & -- & -- & -- & -- & -- & -- & -- & -- & -- & 1 & -- & -- \\
\hline Atherinidae & (silversides) & & & & & & & & & & & & \\
\hline Labidesthes sicculus (Cope, 1865) & brook silverside & 3 & 1 & -- & -- & -- & -- & -- & -- & -- & -- & -- & -- \\
\hline Centrarchidae & (sunfishes) & & & & & & & & & & & & \\
\hline Ambloplites rupestris (Rafinesque, 1817) & rock bass & 7 & 9 & -- & 21 & -- & 17 & -- & 1 & -- & -- & -- & 1 \\
\hline Lepomis cyanellus Rafinesque, 1819 & green sunfish & 29 & 10 & -- & 24 & 3 & 6 & 1 & 3 & 4 & 6 & 19 & 4 \\
\hline Lepomis macrochirus Rafinesque, 1819 & bluegill & 63 & 61 & 22 & 113 & 36 & 109 & 5 & 4 & 5 & 1 & 146 & 73 \\
\hline Lepomis megalotis (Rafinesque, 1820) & longear sunfish & 8 & 9 & 61 & 354 & 39 & 132 & 3 & 41 & -- & -- & 1 & 1 \\
\hline Lepomis microlophus (Gunther) & redear sunfish & -- & -- & -- & 6 & -- & 2 & -- & -- & -- & -- & -- & -- \\
\hline Micropterus dolomieu Lacepede, 1802 & smallmouth bass & 4 & 3 & 3 & 11 & 8 & 13 & -- & 14 & -- & -- & 4 & 2 \\
\hline Micropterus punctulatus (Rafinesque, 1819) & spotted bass & 4 & 15 & -- & 11 & 5 & 2 & -- & 1 & -- & 1 & -- & 1 \\
\hline Micropterus salmoides (Lacepede, 1802) & largemouth bass & 3 & -- & 14 & 6 & 6 & 15 & 1 & 1 & -- & -- & 8 & 1 \\
\hline Pomoxis annularis Rafinesque & white crappie & -- & 1 & -- & 1 & -- & 1 & -- & -- & -- & -- & -- & -- \\
\hline Pomoxis nigromaculatus (Lesueur, 1829) & black crappie & -- & -- & -- & -- & -- & 1 & -- & -- & -- & -- & -- & -- \\
\hline Percidae & (perches and darters) & & & & & & & & & & & & \\
\hline Etheostoma blennioides Rafinesque, 1819 & greenside darter & 35 & 22 & -- & -- & 2 & 14 & -- & -- & -- & -- & 35 & 11 \\
\hline Etheostoma caeruleum Storer, 1845 & rainbow darter & 7 & 11 & -- & 1 & -- & 5 & 3 & 5 & -- & -- & 55 & 86 \\
\hline Etheostoma nigrum Rafinesque, 1820 & johnny darter & 3 & 16 & -- & -- & -- & -- & -- & -- & -- & -- & -- & 1 \\
\hline Etheostoma spectabile (Agassiz, 1854) & orangethroat darter & -- & -- & -- & -- & 1 & -- & 36 & -- & -- & -- & -- & -- \\
\hline Percina caprodes (Rafinesque, 1818) & logperch & 5 & 4 & -- & -- & 12 & 13 & -- & -- & -- & -- & 1 & 5 \\
\hline Percina maculata (Girard, 1859) & blackside darter & 4 & 2 & -- & -- & -- & 2 & -- & -- & -- & -- & -- & -- \\
\hline Percina phoxocephala (Nelson, 1876) & slenderhead darter & 1 & 1 & -- & -- & -- & -- & -- & -- & -- & -- & -- & -- \\
\hline Percina sciera (Swain, 1883) & dusky darter & -- & -- & -- & -- & 4 & -- & -- & -- & -- & -- & -- & -- \\
\hline & Total number of fish: & 475 & 697 & 212 & 633 & 346 & 401 & 809 & 1,173 & 412 & 399 & 1,108 & 459 \\
\hline & Number of species: & 31 & 34 & 13 & 20 & 25 & 26 & 17 & 19 & 8 & 11 & 17 & 18 \\
\hline & Total weight, in kilograms: & 18.6 & 16.4 & 11.9 & 12.2 & 27.6 & 20.0 & 5.4 & 8.5 & 2.8 & 2.8 & 13.2 & 2.3 \\
\hline
\end{tabular}

${ }^{1}$ Authority and date of the original published proposal of the scientific name. The author's name follows the scientific name and without parenthesis if the species, when originally described, was assigned to the same genus in which it appears; if the species was described in another genus, the author's name appears in parenthesis (Robins and others, 1991). 



\section{Appendixes}

The appendixes are separate documents, available for downloading at-

http://pubs.usgs.gov/sir/2012/5096/

Appendixes:

1. Benthic-invertebrate data (tables 1-1 through 1-178)

2. Fish-community data (tables 2-1 through 2-26)

3. Streambed-sediment chemistry data (tables 3-1 through 3-6) 




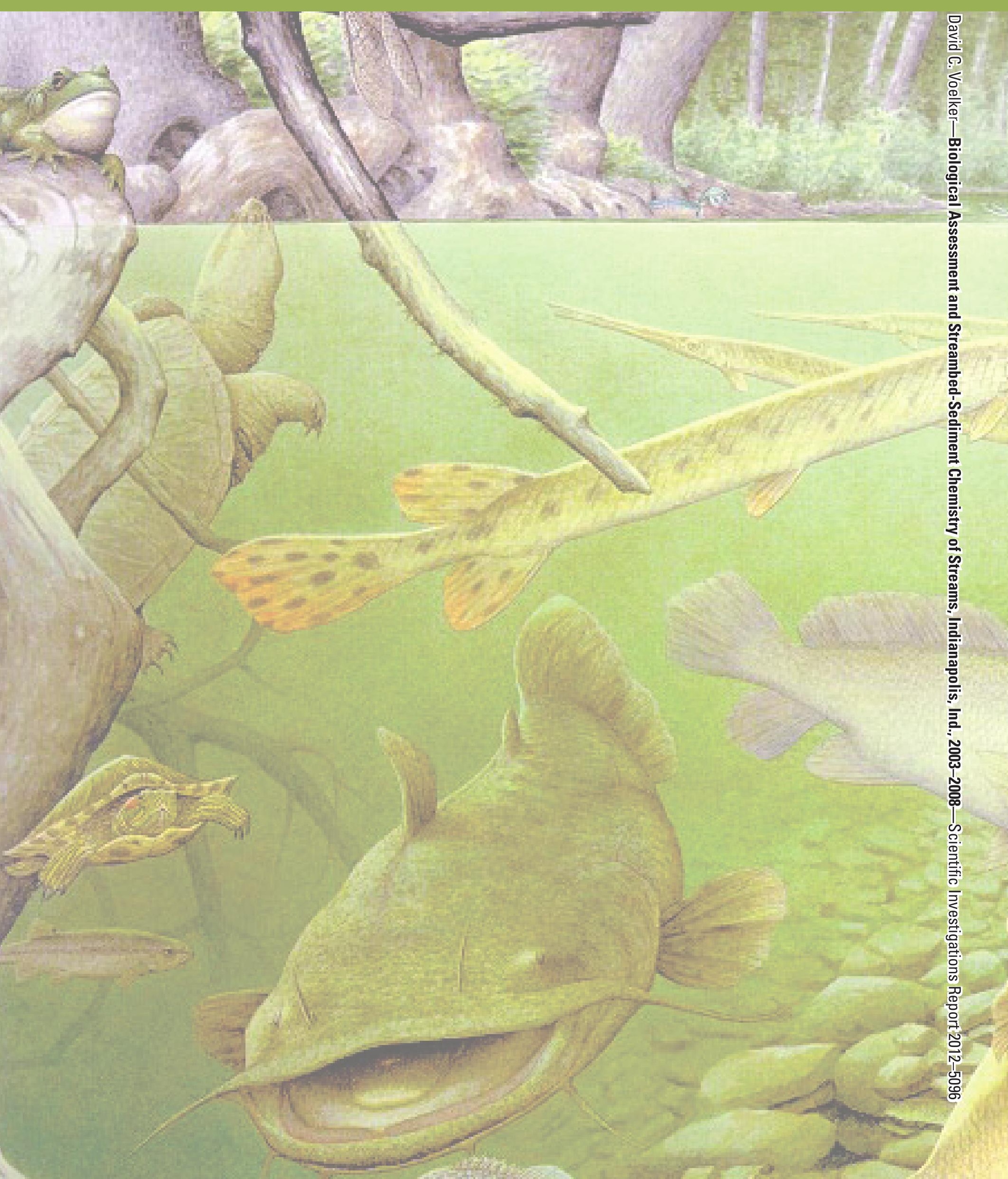

